\title{
EVALUATION OF GROUNDWATER MOVEMENT IN THE FRENCHMAN FLAT CAU USING GEOCHEMICAL AND ISOTOPIC ANALYSIS
}

\author{
Prepared by \\ R.L. Hershey, J.M. Thomas, T.P. Rose, J.B. Paces, I.M. Farnham and F.C. Benedict Jr.
}

\author{
submitted to \\ Nevada Site Office \\ National Nuclear Security Administration \\ U.S. Department of Energy \\ Las Vegas, Nevada
}

MARCH 2005

Publication No. 45207 
Reference herein to any specific commercial product, process, or service by trade name, trademark, manufacturer, or otherwise, does not necessarily constitute or imply its endorsement, recommendation, or favoring by the United States Government or any agency thereof or its contractors or subcontractors. The views and opinions of authors expressed herein do not necessarily state or reflect those of the United States Government or any agency thereof.

This report has been reproduced directly from the best available copy.

Available for sale to the public, in paper, from:

U.S. Department of Commerce

National Technical Information Service

5285 Port Royal Rd.

Springfield, VA 22161

phone: 800.553 .6847

fax: 703.605.6900

email: order@ntis.gov

online ordering: http://www.ntis.gov/ordering.htm

Available electronically at http://www.osti.gov/bridge

Available for a processing fee to the U.S. Department of Energy and its contractors, in paper, from:

U.S. Department of Energy

Office of Scientific and Technical Information

P.O. Box 62

Oak Ridge, TN 37831-0062

phone: 865.576 .8401

fax: 865.576.5728

email: reports@adonis.osti.gov 


\title{
EVALUATION OF GROUNDWATER MOVEMENT IN THE FRENCHMAN FLAT CAU USING GEOCHEMICAL AND ISOTOPIC ANALYSIS
}

\author{
Prepared by \\ R.L. Hershey ${ }^{1}$, J.M. Thomas ${ }^{1}$, T.P. Rose ${ }^{2}$, J.B. Paces ${ }^{3}$, I.M. Farnham ${ }^{4}$ and F.C. Benedict Jr. ${ }^{4}$ \\ Division of Hydrologic Sciences \\ Desert Research Institute \\ University and Community College System of Nevada
}

Publication No. 45207

Submitted to

Nevada Site Office

National Nuclear Security Administration

U.S. Department of Energy

Las Vegas, Nevada

May 2004

\footnotetext{
${ }^{1}$ Desert Research Institute, University and Community College System of Nevada

${ }^{2}$ Analytical and Nuclear Chemistry Division, Lawrence Livermore National Laboratory, Livermore, CA

${ }^{3}$ U.S. Geological Survey, Denver, CO

${ }^{4}$ Stoller-Navarro Joint Venture, Las Vegas, NV
}

The work upon which this report is based was supported by the U.S. Department of Energy under Contract \#DE-AC52-00NV13609. Approved for public release; further dissemination unlimited. 
THIS PAGE LEFT INTENTIONALLY BLANK 


\section{ABSTRACT}

The principal pathway for radionuclide migration from underground tests in Frenchman Flat to the accessible environment is groundwater flow. Two potential pathways for radionuclide transport via groundwater have been identified from hydrologic data: (1) radionuclide transport downward from the alluvial and volcanic aquifers into the underlying carbonate aquifer; and (2) radionuclide transport laterally to the carbonate aquifer surrounding Frenchman Flat. This report presents an evaluation of geochemical and environmental isotopic data to test these potential pathways and to identify other groundwater flowpaths in, and out of, Frenchman Flat.

The approach to identify and test potential groundwater flowpaths included compiling and evaluating geochemical and isotopic data and then constructing mixing models using conservative tracers, strontium data, major-ion chemistry, and isotopes of hydrogen, oxygen, and carbon. Flowpaths defined in the Frenchman Flat groundwater modeling approach were considered. These focused on groundwater flow from alluvial and volcanic aquifers to the Lower Carbonate Aquifer from north to south, vertically downward, and from west to east. Additionally, flow in the Lower Carbonate Aquifer from Frenchman Flat to the southern boundary of the Nevada Test Site was modeled.

Modeling results showed that the geochemical and isotopic data did not support the present conceptual models of groundwater flow in the alluvial and volcanic aquifers. West-toeast flow in the alluvial aquifer to the carbonate aquifer in eastern Frenchman Flat was not substantiated with conservative tracers or Sr data. Geochemical modeling produced one northto-south flowpath from the deep volcanic aquifer to the Lower Carbonate Aquifer consisting of over 90 percent Spring Mountains groundwater with less than 10 percent volcanic water. This mixture modeled groundwater at Army \#1 Water Well on the southern boundary of the Nevada Test Site. However, Sr data, and models with $\delta \mathrm{D}$, showed that this flowpath is unlikely. Testing of vertical leakage from the overlying alluvial and volcanic aquifers to the Lower Carbonate Aquifer with conservative tracers showed several mixtures that reproduced the groundwater chemistry at ER-5-3 \#2. Unfortunately, neither Sr data, models with $\delta \mathrm{D}$, nor carbon isotopes supported these mixtures.

Geochemical and isotopic data did support movement of Lower Carbonate Aquifer groundwater southwestward out of Frenchman Flat. This flowpath required a mixture of Frenchman Flat carbonate aquifer groundwater, Spring Mountains groundwater, and local recharge; however, the amount of each component varied widely. For the mixtures with the best agreement between the geochemical and isotopic data, the amount of Frenchman Flat Lower Carbonate Aquifer water making up the downgradient groundwater on the southern boundary of the Nevada Test Site was relatively small, from three to 14 percent. Modeled ${ }^{14} \mathrm{C}$ travel times ranged from 4,300 to 6,800 years.

The interpretations in this report, based on geochemical and isotopic data, suggest that migration of radionuclides out of the alluvial and volcanic aquifers in Frenchman Flat into the Lower Carbonate Aquifer is unlikely. But, if radionuclides were to migrate into the Lower Carbonate Aquifer beneath Frenchman Flat, a viable groundwater flowpath from Frenchman Flat to the southern boundary of the Nevada Test Site probably exists. However, it is important to note that the interpretations of this report are limited by the uneven spatial 
distribution of wells within the study area and by a paucity of wells completed in the Lower Carbonate Aquifer, both in and downgradient of Frenchman Flat. 


\section{CONTENTS}

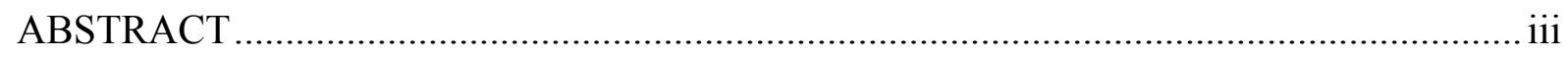

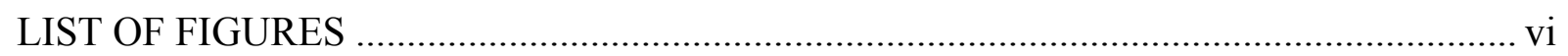

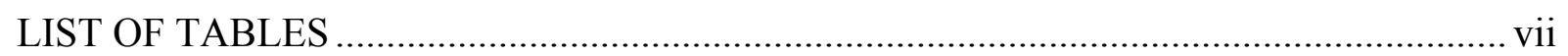

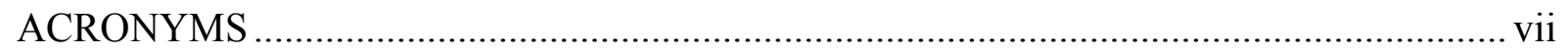

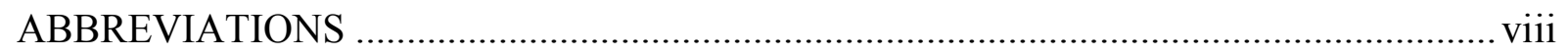

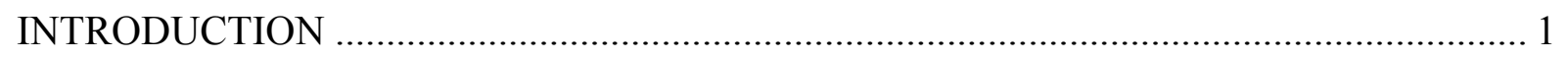

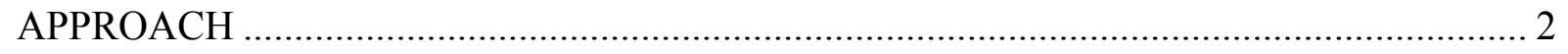

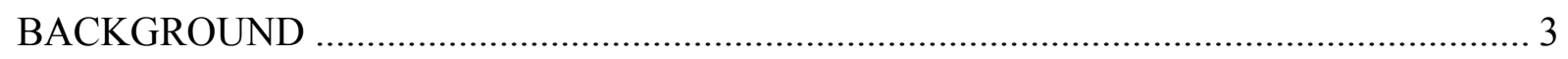

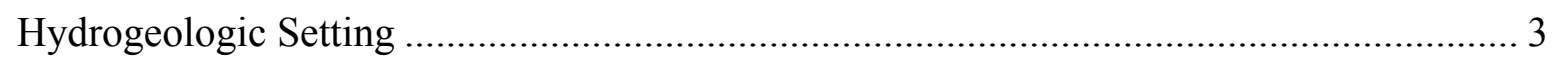

Death Valley Regional Flow System ..................................................................... 3

Hydrostratigraphy of Frenchman Flat........................................................................ 3

Nature and Distribution of Reactive Mineral Phases in Frenchman Flat............................. 4

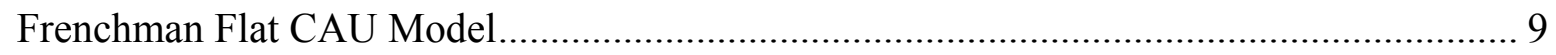

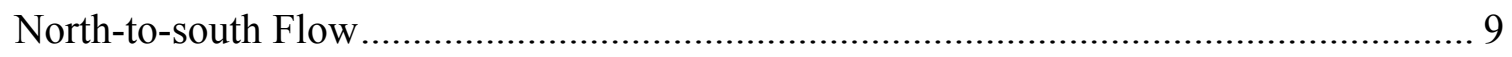

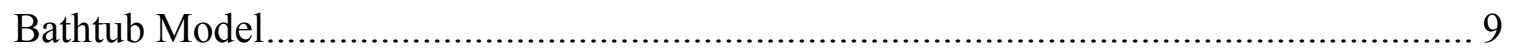

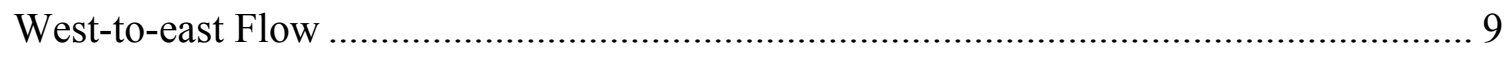

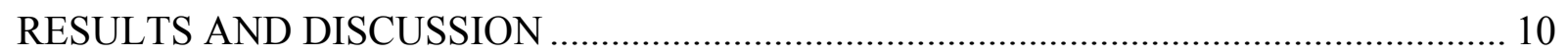

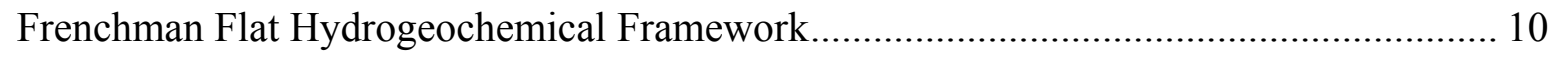

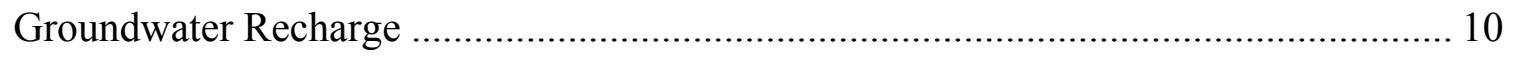

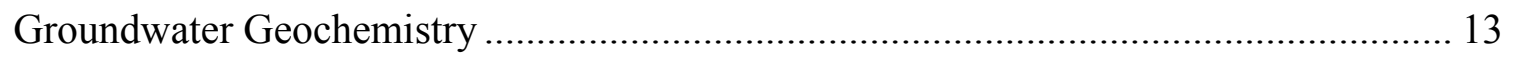

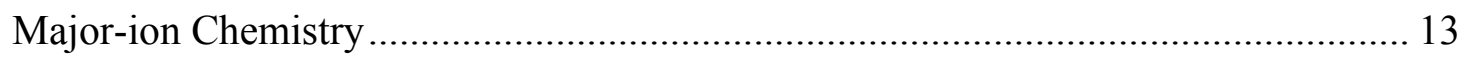

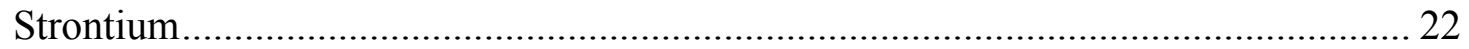

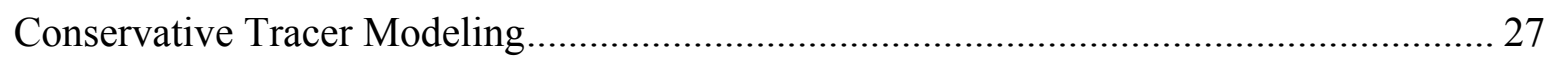

Evaluation of Conservative Tracers in Frenchman Flat................................................... 27

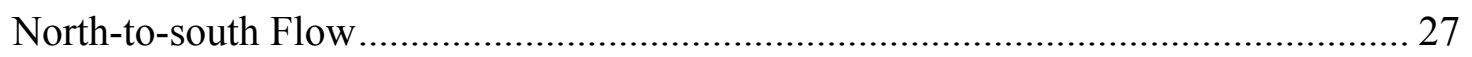

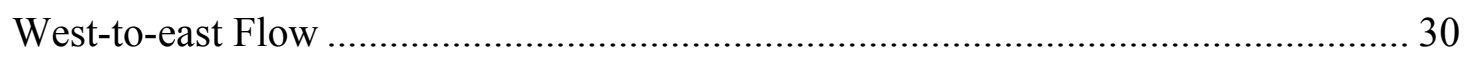

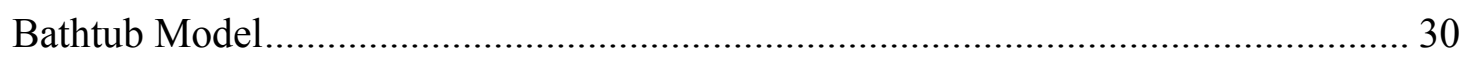

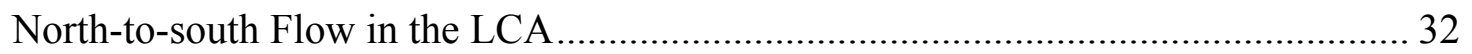

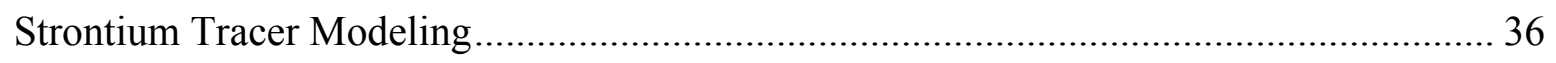

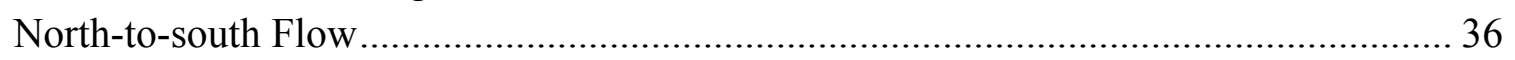

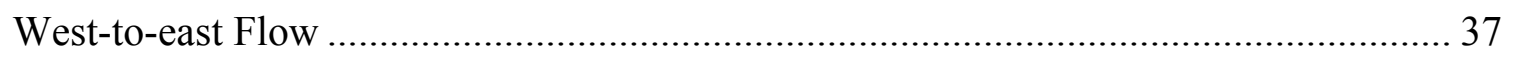

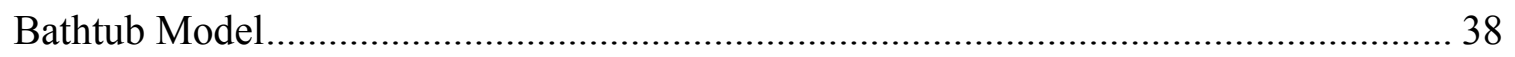

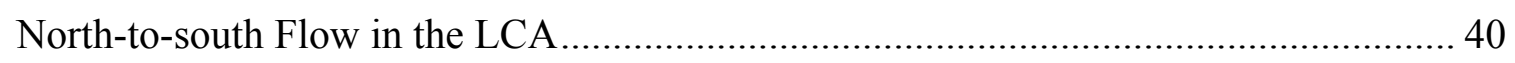

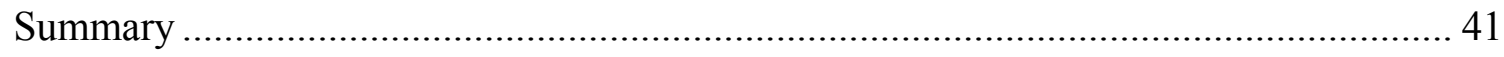

Water-rock Reaction Models and Travel-time Estimates .................................................... 44

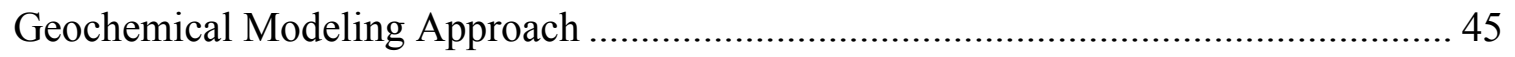

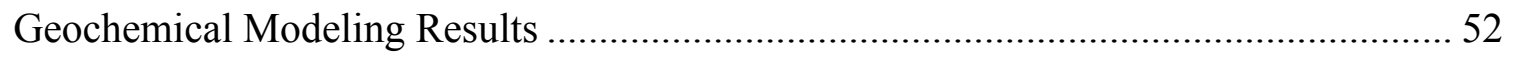

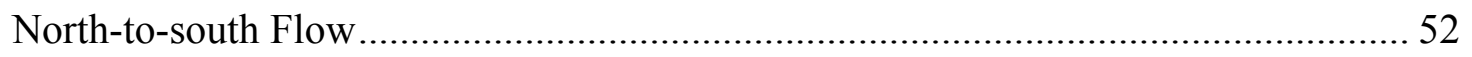

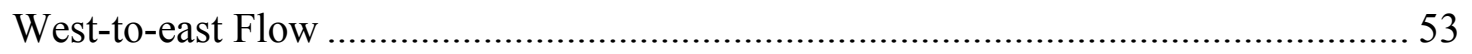




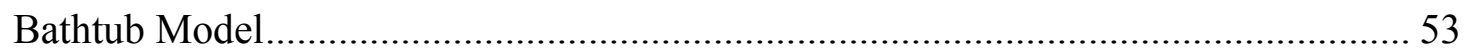

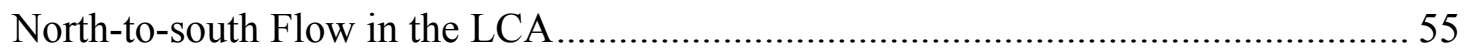

Geochemical Models and Travel Times for Proposed Flowpaths - Summary ................. 56

Groundwater Age Estimates from DOC Carbon-14 ……........................................... 57

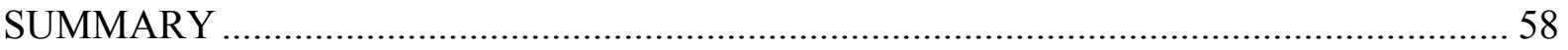

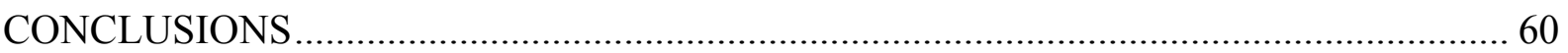

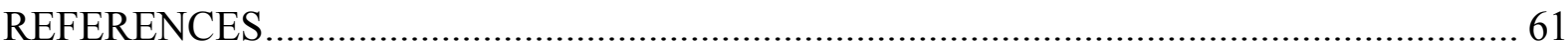

APPENDIX A: Frenchman Flat sample location, geochemical, and isotopic data ............... A-1

APPENDIX B: All NETPATH models. Mass transfers are in millimoles per liter .............. B-1

\section{LIST OF FIGURES}

1. Location of Frenchman Flat at the Nevada Test Site in southern Nevada......................... 1

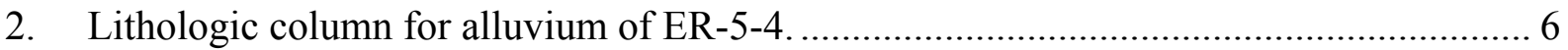

3. Vertical distribution of mineral phases in Frenchman Flat alluvium as determined by $\mathrm{x}$-ray diffraction analysis of samples from borehole ER-5-4 ......................................... 7

4. Location map of the precipitation collection sites and springs at the Nevada

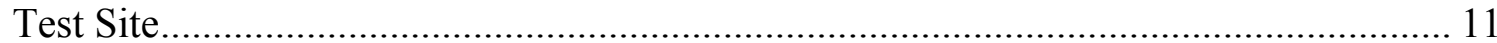

5. The available $\delta \mathrm{D}$ and $\delta^{18} \mathrm{O}$ of discharge water from Whiterock and Cane springs......... 13

6. Comparison of the isotopic composition of Frenchman Flat groundwater to recent local

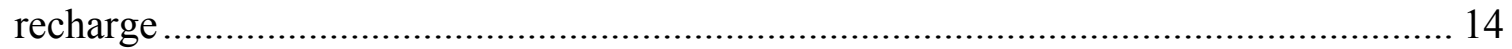

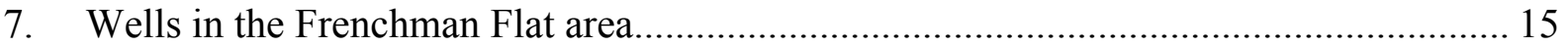

8. Trilinear diagram showing the proportion of major ions in percent equivalents per million in the alluvial (blue circles), volcanic (red squares), and carbonate (purple diamonds) hydrostratigraphic units in Frenchman Flat and vicinity. ............................. 16

9. Stiff diagrams showing milliequivalents per liter of major ions in groundwater in the alluvial aquifer in Frenchman Flat. ........................................................................... 18

10. Stiff diagrams showing milliequivalents per liter of major ions in groundwater in the volcanic hydrostratigraphic units in Frenchman Flat...................................................... 19

11. Total dissolved solids in groundwater compared to depth of the bottom of the screened interval in wells in Frenchman Flat................................................................ 20

12. Stiff diagrams showing milliequivalents per liter of major ions in groundwater in the carbonate aquifer in Frenchman Flat............................................................................... 21

13. Concentrations of $\mathrm{Sr}$ and $\mathrm{Ca}$ in selected groundwater samples in the Frenchman Flat

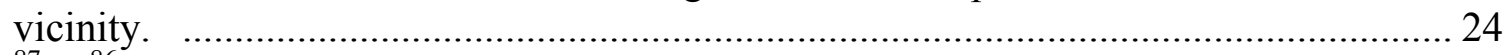

14. ${ }^{87} \mathrm{Sr} /{ }^{86} \mathrm{Sr}$ ratios and $\mathrm{Sr}$ concentrations for selected water samples in the Frenchman

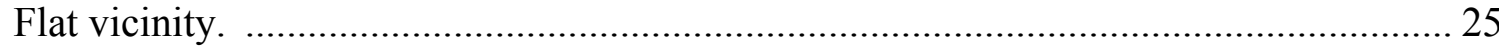

15. Relations between ${ }^{87} \mathrm{Sr} /{ }^{86} \mathrm{Sr}, \mathrm{Cl}$ concentrations, and $\delta \mathrm{D}$ for selected water samples in the

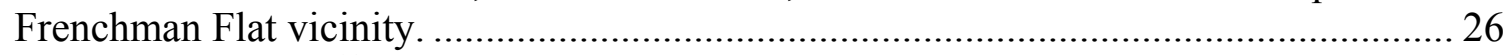

16. Plot of $\delta \mathrm{D}$ versus $\delta^{18} \mathrm{O}$ values for groundwater from Frenchman Flat and vicinity........ 29

17. Plot of $\mathrm{Cl}$ concentrations versus $\delta^{18} \mathrm{O}$ values for groundwater from Frenchman Flat

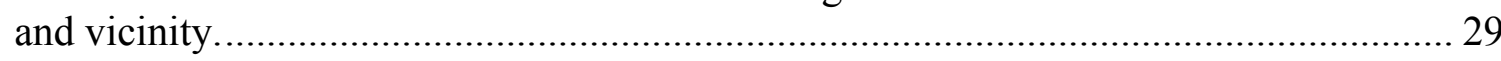

18. Plot of $\mathrm{Cl}$ versus $\delta \mathrm{D}$ values for groundwater samples from Frenchman Flat and vicinity showing the potential mixing relationship between wells ER-3-1 and UE-5 PW-3 ....... 32 
19. Plot of $\mathrm{Cl}$ versus $\delta \mathrm{D}$ values for groundwater samples from Frenchman Flat and vicinity showing one possible three-component mixing model to explain the observed groundwater composition of Army \#1 Water Well.

20. Plot of ${ }^{36} \mathrm{Cl} / \mathrm{Cl}$ versus $1 / \mathrm{Cl}$ for groundwater samples from Frenchman Flat and vicinity

21. Sr mixing plot $\left({ }^{87} \mathrm{Sr} /{ }^{86} \mathrm{Sr}\right.$ versus $\left.1 / \mathrm{Sr}\right)$ for selected water samples in the Frenchman Flat vicinity.

22. Results of binary mixing of selected end-member compositions on ${ }^{87} \mathrm{Sr} /{ }^{86} \mathrm{Sr}$ versus $\mathrm{Cl}$ and ${ }^{87} \mathrm{Sr} /{ }^{86} \mathrm{Sr}$ versus $\delta \mathrm{D}$.

23. Concentration of $\mathrm{Sr}$ versus $\mathrm{Cl}$ and $\mathrm{Sr}$ versus $\delta \mathrm{D}$ for selected samples from the Frenchman Flat vicinity.

24. Three-component mixing models for USGS HTH \#3, Indian Springs, and Cane Spring end members.

\section{LIST OF TABLES}

1. Hydrostratigraphic units for Frenchman Flat........................................................ 4

2. Average mineral abundances (wt percent) within alluvial layers of borehole ER-5-4 ..... 8

3. Location and elevation of isotopic precipitation sampling stations below $1,830 \mathrm{~m}$ elevation near Frenchman Flat. 12

4. Total dissolved solids concentrations for wells in the vicinity of Frenchman Flat......... 17

5. Well completion and hydraulic head data for wells located in Frenchman Flat and vicinity. 28

6. Carbon-13 data for alluvium, vein calcite in volcanic rocks, and carbonate rock.......... 46

7. Summary of conservative mixing and geochemical models....................................... 48

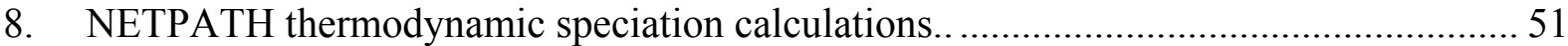

9. Dissolved organic carbon calculated groundwater ages. ....................................... 57

\section{ACRONYMS}

$\begin{array}{ll}\text { AA } & \text { alluvial aquifer } \\ \text { CAU } & \text { Corrective Action Unit } \\ \text { CP } & \text { Control Point } \\ \text { DOC } & \text { dissolved organic carbon } \\ \text { FFACO } & \text { Federal Facility Agreement and Consent Order } \\ \text { HSU } & \text { hydrostratigraphic units } \\ \text { LCA } & \text { Lower Carbonate Aquifer } \\ \text { LCCU } & \text { Lower Clastic Confining Unit } \\ \text { NTS } & \text { Nevada Test Site } \\ \text { SI } & \text { saturation index } \\ \text { TMA } & \text { Timber Mountain Aquifer } \\ \text { TCU } & \text { Tuff Confining Unit } \\ \text { UGTA } & \text { Underground Test Area Project } \\ \text { VCCU } & \text { Volcaniclastic Confining Unit } \\ \text { WVCU } & \text { Wahmonie Volcanic Confining Unit }\end{array}$




\section{ABBREVIATIONS}

\begin{tabular}{lll} 
Abbreviations & & Well or Spring Name \\
\cline { 1 - 1 } ATW\#2 & & Amargosa Tracer Well \#2 \\
Army\#1 & & Army \#1 Water Well \\
Cane Sp & & Cane Spring \\
Cold Creek Sp & & Cold Creek Spring \\
3-1 & & ER-3-1 \\
5-3 & & ER-5-3 \\
5-3\#2 & & ER-5-3 \#2 \\
5-4 & ER-5-4 \\
5-4\#2 & ER-5-4 \#2 \\
6-1 & ER-6-1 \\
6-1\#2 & ER-6-1 \#2 \\
Indian Sps & Indian Springs \\
Quartz Sp & Quartz Spring \\
PW1 & UE-5 PW-1 \\
PW2 & UE-5 PW-2 \\
PW3 & UE-5 PW-3 \\
UE-5cWW & UE-5c Water Well \\
UE-11a & UE-11a \\
HTH3 & USGS HTH \#3 \\
TWB & USFS Test Well B \\
TWF & USGS Test Well F \\
WWC & USGS Water Well C \\
WW1 & Water Well 1 \\
WWC-1 & Water Well C-1 \\
WW4 & Water Well \#4 \\
WW4A & Water Well 4A \\
WW5A & Water Well 5A \\
WW5B & Water Well 5B \\
WW5C & Water Well 5C \\
Wiregrass Sp & & \\
& &
\end{tabular}




\section{INTRODUCTION}

The Frenchman Flat Corrective Action Unit (CAU) is one of six underground test areas (Figure 1) on the Nevada Test Site (NTS) specified for remedial action in the Federal Facility Agreement and Consent Order (FFACO, 1996). Because of the small number of underground nuclear tests conducted there (10 underground tests), the Frenchman Flat CAU has one of the smallest residual radionuclide inventories of the six CAUs (Bowen et al., 1994). Nine tests were conducted in the alluvial aquifer and one in the volcanic aquifer, all within 100 meters of the water table. The principal mechanism for radionuclide transport from underground tests to the accessible environment is groundwater flow.

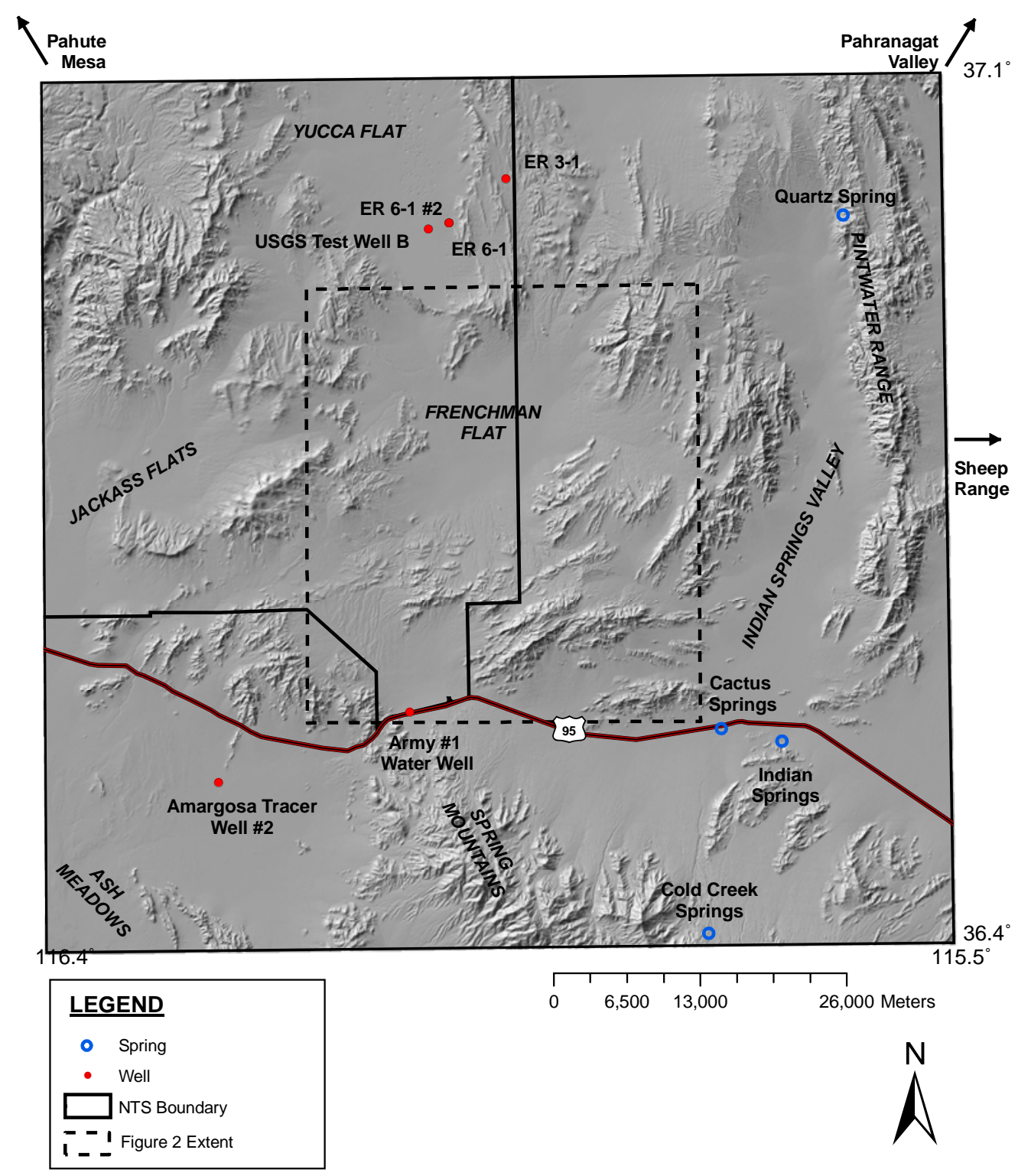

Figure 1. Location of Frenchman Flat at the Nevada Test Site in southern Nevada.

This report presents an evaluation of geochemical and environmental isotopic data to identify potential pathways of groundwater movement for the Frenchman Flat CAU. 
Geochemical and isotopic data constrain groundwater origin, flowpath, and travel time. These data can therefore be used to test numerical groundwater flow model results. From hydrologic data, two potential pathways for radionuclide transport via groundwater from Frenchman Flat have been identified: (1) radionuclide transport downward from tests in the alluvial and volcanic aquifers into the underlying carbonate aquifer; and (2) radionuclide transport laterally from tests to the carbonate aquifer surrounding Frenchman Flat.

\section{APPROACH}

This study examines geochemical and isotopic data to identify the origin, pathway, and timescale of groundwater flow within the Frenchman Flat CAU. To achieve this goal, a variety of geochemical techniques were applied (e.g., Benedict et al., 2003). The approach included:

(1) A set of geochemical data from groundwater within the study area was compiled from the comprehensive water quality database, Geochem03.mdb (SNJV, 2004). The data set was then supplemented with additional data obtained following the release of the database. Individual major-ion analyses were evaluated for charge balance. The most recent major-ion analysis with the best charge balance was selected to represent the water chemistry of a particular well or spring. Average isotopic values were used to represent the isotopic signature of each well or spring.

(2) Groundwater mixing models were tested for several conceptual flowpaths using conservative tracer data. Conservative tracers are those geochemical species that exhibit little or no tendency to interact with aquifer material and that are transported with the groundwater. Conservative tracers used in this study include isotopes of hydrogen $(\delta \mathrm{D})$ and oxygen $\left(\delta^{18} \mathrm{O}\right)$, as well as $\mathrm{Cl}$.

(3) Conceptual flowpaths were also evaluated by examining strontium ( $\mathrm{Sr}$ ) concentrations and ${ }^{87} \mathrm{Sr} /{ }^{86} \mathrm{Sr}$ isotopic ratios. Strontium, a non-conservative, reactive element, provides an assessment of a particular flowpath independent of the conservative tracers.

(4) Flowpaths with acceptable conservative mixing and $\mathrm{Sr}$ reaction models were then evaluated using the geochemical modeling program NETPATH (Plummer et al., 1994). This program is used to interpret net geochemical mass-balance reactions between initial and final water compositions along a hydrologic flowpath. NETPATH also provides estimates of groundwater travel times and corrected radiocarbon ages.

(5) Important flowpaths identified by conservative tracers, Sr, and NETPATH modeling were also evaluated using the program PHREEQC. This program provides insight into mineral saturation states and allows the direct comparison of predicted dissolutionprecipitation reactions with the mineral compositions observed in borehole core samples. PHREEQC also provides a means of quantifying uncertainties in mixing ratios and the quantities of the minerals dissolved or precipitated. 


\section{BACKGROUND}

\section{Hydrogeologic Setting}

\section{Death Valley Regional Flow System}

The NTS is located within the Death Valley groundwater flow system, a large regional aquifer system encompassing $41,000 \mathrm{~km}^{2}$ within the southern Great Basin (Harrill et al., 1988; Laczniak et al., 1996). The rocks that comprise the major hydrogeologic units within this flow system include a thick sequence $(>10.6 \mathrm{~km})$ of Precambrian through Paleozoic carbonate and clastic rocks, Tertiary rhyolitic and quartz latitic volcanic rocks of variable thickness, and locally thick chiefly Quaternary deposits of post-volcanic gravel and sand that fill the valleys (Frizzell and Shulters, 1990; Laczniak et al., 1996). Mesozoic thrust faulting and Cenozoic normal faulting have juxtaposed rocks of different ages, lithologies, and hydraulic properties, locally compartmentalizing the regional flow. For this reason, hydraulic gradients are generally step-like rather than smooth (Winograd and Thordarson, 1975).

The Lower Carbonate Aquifer (LCA) and Lower Clastic Confining Unit (LCCU) are the most extensive hydrostratigraphic units (HSUs) within the region and therefore predominately control the groundwater flow (US DOE, 1997). The carbonate rocks of the LCA are the most transmissive of the aquifer materials because of the relatively high solubility of carbonate rocks and the abundant secondary permeability in fractures (Laczniak et al., 1996). The LCCU is generally considered impermeable, although it may locally exhibit hydraulic properties consistent with an aquifer because of fracturing. The LCA forms a nearly continuous aquifer across the region except where interrupted by calderas, truncated by structural controls (such as structural highs of the LCCU), or penetrated by intrusive rocks. The general direction of groundwater flow in the LCA is from north to south and east to southwest (US DOE, 1999). Recharge to the LCA occurs in high-elevation areas in central Nevada, and in the Spring Mountains and Sheep Range in southern Nevada. Major discharge areas occur at Ash Meadows and Death Valley. The hydrogeology and hydrochemistry of the regional carbonate aquifer are described in detail by Winograd and Thordarson (1975), Mifflin and Hess (1979), Prudic et al. (1995), and Thomas et al. (1996).

Other major aquifers include various alluvial and volcanic aquifers. The distribution and thickness of these aquifers are highly variable throughout the region. Saturated alluvial materials are present in central and southern Yucca Flat, Frenchman Flat, and Jackass Flats on the NTS and in other basins located throughout the flow system. The hydraulic conductivity for alluvial aquifers is lower than that of carbonate aquifers such as the LCA, but higher than that of volcanic aquifers. Saturated Tertiary volcanic rocks are common in the western section of the region. These aquifers are discontinuous and are thought to influence regional flow in more localized areas only (US DOE, 1999).

\section{Hydrostratigraphy of Frenchman Flat}

Detailed summaries of the hydrogeology of Frenchman Flat are found in Winograd and Thordarson (1975) and Laczniak et al. (1996). The following is a brief summary of the main hydrogeologic features of the area (IT, 2001). Frenchman Flat is a topographically closed basin in the southeastern part of the NTS. Principal HSUs within the basin include the Paleozoic LCA, various Cenozoic volcanic units, and the alluvial aquifer (AA) (Table 1). The volcanic rocks consist mainly of rhyolitic tuffs that are further subdivided into four units: the Timber Mountain Aquifer (TMA), Wahmonie Volcanic Confining Unit (WVCU), Tuff 
Confining Unit (TCU), and Volcaniclastic Confining Unit (VCCU). The TCU effectively separates the underlying carbonate aquifer from the overlying tuff aquifer and alluvial deposits throughout much of Yucca Flat, and at least part of Frenchman Flat. The lateral extent of the TCU in Frenchman Flat is poorly defined, but has been identified in the areas where underground testing was conducted (Laczniak et al., 1996). The alluvial aquifer extends to the Frenchman Flat CAU boundaries although it is generally unsaturated except in central Frenchman Flat (US DOE, 1999).

Table 1. Hydrostratigraphic units for Frenchman Flat (IT, 2001).

\begin{tabular}{ll}
\hline \multicolumn{1}{c}{ CAU-scale Model Hydrostratigraphic Unit } \\
\hline AA & Alluvial Aquifer \\
TMA & Timber Mountain Aquifer \\
WVCU & Wahmonie Volcanic Confining Unit \\
TCU & Tuff Confining Unit \\
VCCU & Volcaniclastic Confining Unit \\
UCCU & Upper Clastic Confining Unit \\
LCA & Lower Carbonate Aquifer \\
LCCU & Lower Clastic Confining Unit \\
\hline
\end{tabular}

\section{Nature and Distribution of Reactive Mineral Phases in Frenchman Flat}

The nature and distribution of potentially reactive mineral phases in Frenchman Flat are important considerations because, through the process of water-rock interaction, these phases can act as a source (as a result of dissolution) or sink (as a result of precipitation or adsorption) for solutes in groundwater. This can have a significant influence on both the major ion chemistry of groundwater (and therefore be an important component in flowpath analysis) and radionuclide mobility. Hydrologic source term modeling at the Cambric underground test site (Pawloski et al., 2000) showed that radionuclide transport is highly sensitive to the abundance and availability of reactive secondary minerals. The geochemical evaluation of the Pahute Mesa flow system (Thomas et al., 2002) has demonstrated the important role that solid phases have in constraining flowpaths and travel time estimates. Underground nuclear testing in Frenchman Flat has occurred primarily within the basin-fill alluvium. Consequently, the geochemical constraints on groundwater chemistry and radionuclide transport within the alluvium are of specific interest.

Warren et al. (2002) provides detailed information on the nature and distribution of reactive minerals in alluvium from Frenchman Flat. This investigation was focused on the analysis of newly acquired samples from drill hole ER-5-4, located in the southern testing area of Frenchman Flat, but also included analyses on alluvial samples from other boreholes in the basin.

The integrated results from these analyses provide detailed information on the general character and origin of alluvium within the Frenchman Flat basin. Twelve alluvial layers are defined based primarily on lithologic variation and further refined by measured abundances of key minerals. Correlations with data from other boreholes in Frenchman Flat indicate that alluvium has probably accumulated throughout the basin as irregular layers within fans largely comprised of the most prominent lithologies within proximal uplifted structural blocks. 
The significant findings of Warren et al. (2002) are represented in Figures 2 and 3 and Table 2 and include:

- Alluvium in Frenchman Flat consists of lithologically, chemically, and/or mineralogically distinctive layers. In the vicinity of ER-5-4, 12 individual layers are identified that can be recognized in nearby boreholes. The intra-layer variability is far less significant than the inter-layer variability;

- These layers contain an abundance of volcanic glass and have been altered very little since deposition. This suggests that water-rock interaction processes in Frenchman Flat have not been pervasive or widespread;

- Comparative chemical and mineralogical analyses demonstrate that alluvium in the northern testing area of Frenchman Flat differs from the alluvium in the southern testing area;

- Reactive minerals within alluvium are partitioned among three components: crystals (phenocrysts), lithics, and matrix; only those reactive minerals within the matrix are expected to interact with groundwater;

- Reactive Fe and Mn oxides occur in measurable abundances within Frenchman Flat alluvium;

- Clay ubiquitously coats other authigenic reactive minerals within matrix, limiting their reactivity according to accessibility estimates determined during SEM analysis;

- Smectite group clay (probably mixed or interlayered with lesser amounts of illite and a silica polymorph) is typically abundant and provides the majority of the internal surface area available to interact with groundwater;

- Zeolite minerals (predominantly clinoptilolite), while locally abundant, occur most prevalently in lithic fragments and shards. The low surface area to volume ratio of the lithics and armoring by matrix clays probably limits the opportunity for interaction of zeolites with groundwater; and

- Carbonate minerals (predominantly secondary calcite) are common in the matrix of the deeper layers, and have a relatively high availability for interaction with groundwater. 


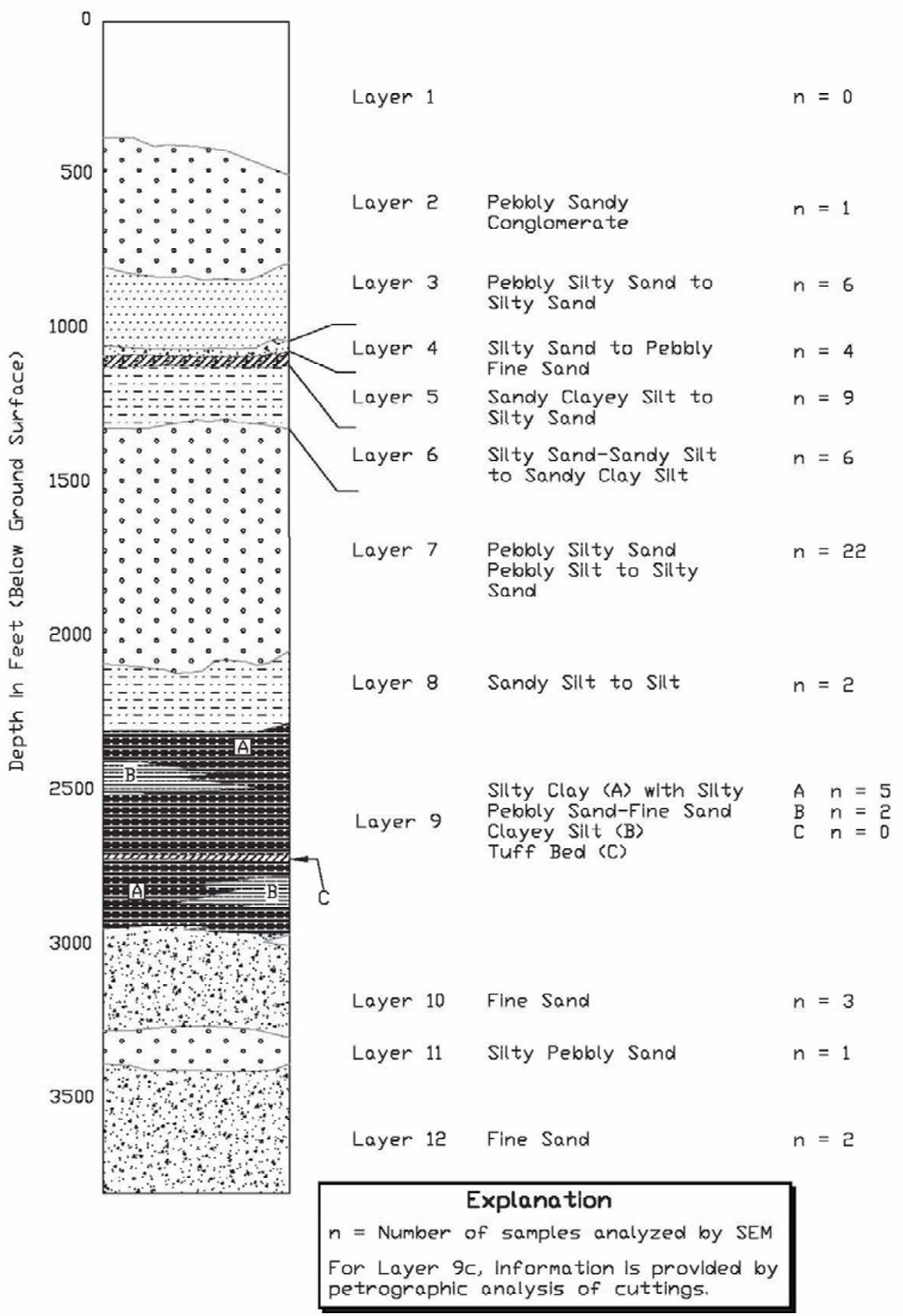

Figure 2. Lithologic column for alluvium of ER-5-4. 


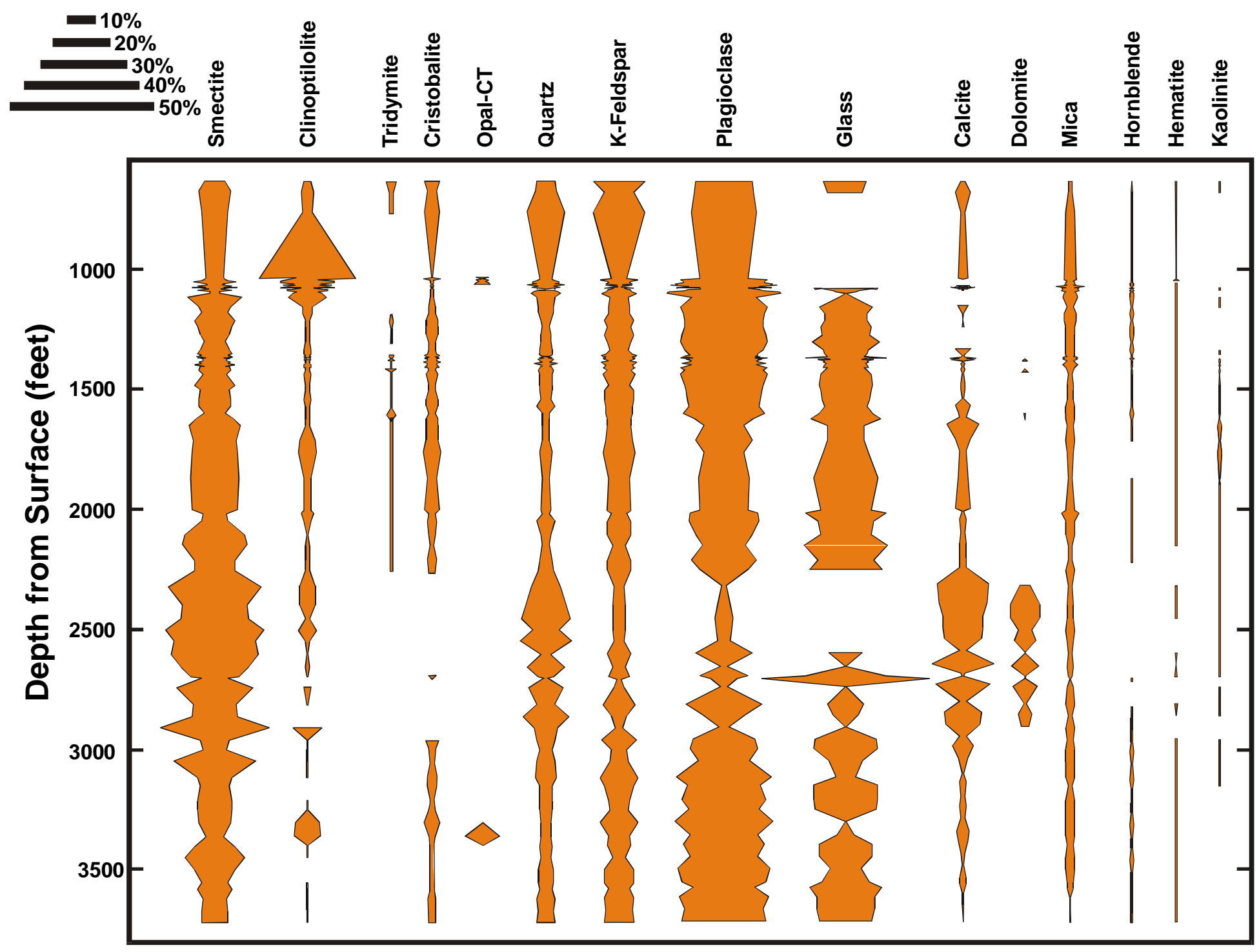

Figure 3. Vertical distribution of mineral phases in Frenchman Flat alluvium as determined by x-ray diffraction analysis of samples from borehole ER-5-4 (Warren et al., 2002). 
Table 2. Average mineral abundances (wt percent) within alluvial layers of borehole ER-5-4, based on quantitative x-ray diffraction (QXRD) analyses (Warren et al., 2002).

\begin{tabular}{|c|c|c|c|c|c|c|c|c|c|c|c|c|c|c|c|c|c|c|c|c|c|c|c|}
\hline \multirow{2}{*}{$\begin{array}{c}\text { layer } \\
2\end{array}$} & \multirow{2}{*}{$\begin{array}{l}\mathrm{n} \\
3\end{array}$} & \multicolumn{2}{|c|}{ glass } & \multicolumn{2}{|c|}{ clinoptilolite } & \multicolumn{2}{|c|}{ opal } & \multicolumn{2}{|c|}{ calcite } & \multicolumn{2}{|c|}{ dolomite } & \multicolumn{2}{|c|}{ smectite } & \multicolumn{2}{|c|}{ mica/illite } & \multicolumn{2}{|c|}{ hematite } & \multicolumn{2}{|c|}{ plag } & \multicolumn{2}{|c|}{ K-spar } & \multicolumn{2}{|c|}{ quartz } \\
\hline & & 11.5 & 5.8 & 3.9 & 0.8 & 0 & & 3.4 & 1.6 & 0 & & 11.2 & 1.2 & 2.6 & 0.7 & 0.43 & 0.03 & 26 & 1 & 19.0 & 3.0 & 10.9 & 2.7 \\
\hline 3 & 6 & 0 & & 21.6 & 4.7 & 4.2 & 1.0 & 0.9 & 0.8 & 0 & & 10.5 & 1.7 & 4.6 & 0.5 & 0.43 & 0.24 & 35 & 3 & 10.9 & 1.3 & 8.2 & 0.9 \\
\hline 4 & 4 & 0 & & 17.3 & 2.6 & 0 & & 1.9 & 1.4 & 0 & & 12.2 & 2.8 & 6.2 & 2.1 & 0.48 & 0.03 & 40 & 3 & 10.6 & 0.8 & 9.9 & 2.1 \\
\hline 5 & 9 & 15.6 & 3.4 & 12.2 & 1.4 & 0 & & 2.6 & 1.2 & 0 & & 10.5 & 2.1 & 6.7 & 0.5 & 0.51 & 0.08 & 33 & 3 & 9.0 & 1.0 & 8.0 & 0.8 \\
\hline 6 & 6 & 20.8 & 1.6 & 2.6 & 0.5 & 0 & & 0.9 & 0.6 & 0 & & 13.2 & 1.2 & 4.5 & 0.3 & 0.50 & 0.00 & 36 & 1 & 10.4 & 0.7 & 4.9 & 0.6 \\
\hline 7 & 32 & 20.1 & 0.9 & 2.6 & 0.3 & 0 & & 3.4 & 0.6 & 0.1 & 0.1 & 13.8 & 0.7 & 4.3 & 0.2 & 0.56 & 0.03 & 30 & 1 & 11.4 & 0.3 & 4.9 & 0.3 \\
\hline 8 & 4 & 27.5 & 3.1 & 1.3 & 0.1 & 0 & & 2.7 & 0.3 & 0 & & 22.2 & 2.8 & 3.3 & 0.7 & 0.60 & 0.00 & 23 & 2 & 9.1 & 1.4 & 5.0 & 0.8 \\
\hline $9 \mathrm{~A}$ & 8 & 0 & & 5.3 & 1.3 & 0 & & 19.9 & 1.5 & 8.4 & 1.3 & 35.5 & 2.5 & 3.2 & 0.3 & 0.23 & 0.11 & 5 & 1 & 4.8 & 0.3 & 15.8 & 1.5 \\
\hline $9 \mathrm{~B}$ & 4 & 18.2 & 5.5 & 0.4 & 0.4 & 0 & & 5.9 & 3.3 & 1.8 & 1.3 & 24.5 & 4.5 & 2.8 & 0.6 & 0.35 & 0.13 & 24 & 3 & 10.0 & 1.6 & 9.7 & 3.6 \\
\hline $9 \mathrm{C}$ & 1 & 72.7 & & 0 & & 0 & & 0.4 & & 0 & & 11.9 & & 1.2 & & 0 & & 11 & & 2.3 & & 1.4 & \\
\hline 10 & 7 & 22.2 & 2.9 & 0.3 & 0.1 & 0 & & 3.6 & 0.9 & 0 & & 16.4 & 3.1 & 3.7 & 0.3 & 0.53 & 0.05 & 31 & 2 & 10.7 & 1.5 & 6.5 & 0.6 \\
\hline 11 & 2 & 3.6 & 3.6 & 11.0 & 0.5 & 7.2 & 7.2 & 3.4 & 1.9 & 0 & & 11.1 & 3.1 & 4.1 & 0.0 & 0.50 & 0.10 & 36 & 6 & 12.3 & 3.9 & 4.0 & 0.1 \\
\hline 12 & 8 & 22.5 & 1.8 & 0.5 & 0.1 & 0 & & 1.9 & 0.5 & 0 & & 14.9 & 1.8 & 2.4 & 0.5 & 0.59 & 0.01 & 35 & 2 & 10.8 & 0.9 & 6.5 & 0.5 \\
\hline
\end{tabular}

Note: The number of QXRD analyses available within each alteration layer is $\mathrm{n}$. The second values listed for each element are standard errors of the mean. Analyses include four samples of representative, handpicked cuttings within layer 7 and three samples within layer 12. Figure 2 illustrates distribution of mineralogy within ER-5-4. 


\section{Frenchman Flat CAU Model}

The Frenchman Flat CAU Model is based upon the original Underground Test Area (UGTA) Project regional groundwater model of the NTS region (US DOE, 1997). The regional model is being revised for CAU modeling to include characteristics specific to the Frenchman Flat area (IT, 2001). The revised regional groundwater model is being used to define boundary conditions for the Frenchman Flat CAU model.

As described in IT (2001), the LCA is considered to be the conduit for transporting radionuclides in groundwater beyond Frenchman Flat. Regional groundwater flow within the LCA is from northeast to southwest. In the alluvial and volcanic aquifers overlying the LCA in Frenchman Flat, the groundwater flow directions are more difficult to define. Hydraulic heads indicate semi-perched conditions in the alluvial and volcanic hydrostratigraphic units, suggesting vertical downward flow. However, lateral groundwater flow is also a possibility in these units.

Based upon geography, hydrostratigraphy, water levels, geologic structures, hydraulic properties, and recharge estimates, three conceptual models were proposed to describe groundwater flow in Frenchman Flat. The focus of the conceptual models was groundwater flow in the alluvial aquifer since it was thought that radionuclides in Frenchman Flat groundwater would migrate in the alluvium to the LCA where they could then exit Frenchman Flat.

North-to-south Flow

In this conceptual model, groundwater in Frenchman Flat flows predominantly from north to south, with a slight northeast-to-southwest orientation (IT, 2001). Water levels north of Frenchman Flat are higher than the center of the Frenchman Flat basin and this water would flow into the Frenchman Flat alluvium. From the relatively flat potentiometric surface in the center of the basin, the surface slopes southward. The water in Frenchman Flat drains to the LCA in the south. The CP Basin, west of Frenchman Flat, is assumed to be in a separate flow system, isolated from the rest of Frenchman Flat.

\section{Bathtub Model}

This model assumes that groundwater, particularly in northern and central Frenchman Flat, leaks vertically downward until it reaches the LCA and that vertical hydraulic gradients are much stronger than horizontal gradients (IT, 2001). The water levels in southern Frenchman Flat are interpreted to be lower because of the TCU under the alluvium in this part of the basin. The primary source of water in the basin is recharge from infiltration. The CP Basin again is assumed to be isolated from Frenchman Flat.

\section{West-to-east Flow}

The west-to-east model assumes lateral groundwater flow. In this model, the CP Basin and Mt. Salyer regions are the source of most of the water in the Frenchman Flat alluvium, with a small component from recharge (IT, 2001). Groundwater entering the alluvium from the west flows laterally to the LCA surrounding the basin. In the northern part of Frenchman Flat, groundwater flows northward. In the eastern part of the basin, groundwater in the alluvial and volcanic aquifers flows eastward, and in the southern part of the basin, groundwater flows southward. 


\section{RESULTS AND DISCUSSION}

\section{Frenchman Flat Hydrogeochemical Framework}

\section{Groundwater Recharge}

The stable isotopic composition of precipitation on the NTS was measured from 1982 through 1986 by DRI (Ingraham et al., 1990). The stable isotopes of hydrogen and oxygen can be used to study hydrologic processes since these elements form the water molecule. Phase changes in nature, such as evaporation or condensation, result in fractionation of these isotopes in various hydrologic components, including precipitation, surface water and groundwater, because of the effects of isotopic mass on the rates of reaction. Fractionation is temperature dependent so the history of phase changes in water is recorded in the isotopic composition allowing identification of different water sources. The isotopic composition of precipitation can be used to delineate different sources of groundwater at the NTS.

Southern Nevada, and most of the southwestern U.S., has two precipitation periods, winter and summer. Winter precipitation is produced from frontal systems migrating eastward from the Pacific Ocean and is colder than summer precipitation. Summer rains occur primarily as localized high-intensity convective storms (French, 1983, 1985) from subtropical air masses moving northward from the Gulf of California. Simpson et al. (1972) demonstrated a substantial and predictable difference in stable isotopic composition of precipitation for these two periods. These differences in stable isotopic composition occur because of differences in storm origin, history, temperature, and amount of evaporation during precipitation events. The colder winter precipitation is more isotopically depleted, while the summer storms produce more isotopically enriched precipitation.

Precipitation was collected at 14 sites at the NTS ranging in elevation from 960 to 2,234 m. Two springs, Cane and Whiterock, were also monitored for discharge and stable isotopic composition (Figure 4). Over 400 precipitation samples and about 100 spring samples were analyzed for $\delta^{18} \mathrm{O}$, while about 275 precipitation samples and 70 spring samples were analyzed for $\delta \mathrm{D}$. A local meteoric water line of $\delta \mathrm{D}=6.87 \delta^{18} \mathrm{O}-6.5$ was calculated from the precipitation data (Ingraham et al., 1990), which differs from the global meteoric water line $\left(\delta \mathrm{D}=8 \delta^{18} \mathrm{O}+10\right.$, Craig, 1961).

The Frenchman Flat basin varies in elevation from approximately 940 (Frenchman Lake) to 1,910 m (Aysees Peak in the Buried Hills northeast of Frenchman Lake). But for the most part, the mountains surrounding Frenchman Flat are below 1,830 m, so the summary of precipitation stations reviewed for this study is limited to those found below $1,830 \mathrm{~m}$ in elevation. From Ingraham et al. (1990), the seven isotopic precipitation-monitoring stations examined are listed in Table 3. 


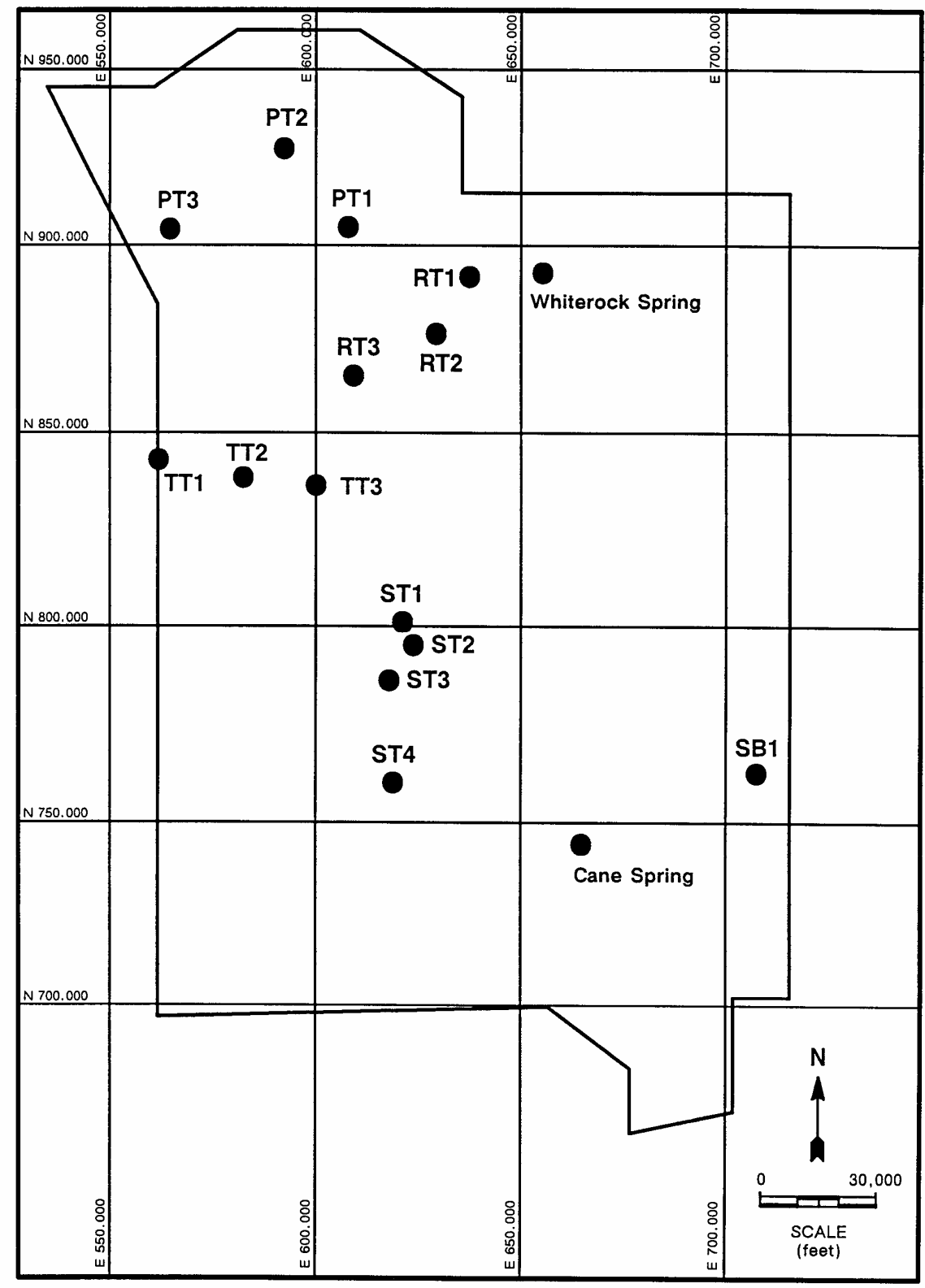

Figure 4. Location map of the precipitation collection sites and springs at the Nevada Test Site (from Ingraham et al., 1990). 
Table 3. Location and elevation of isotopic precipitation sampling stations below $1,830 \mathrm{~m}$ elevation near Frenchman Flat. Also shown are the $\delta \mathrm{D}$ and $\delta^{18} \mathrm{O}$ average for each station weighted by precipitation amount (from Ingraham et al., 1990).

\begin{tabular}{lclllcc}
\hline Station & Elevation & Location N-S & Location E-W & Geographic Area & $\delta \mathrm{D}(\% \mathbf{)})$ & $\delta^{18} \mathrm{O}(\% \mathbf{0})$ \\
\hline SB1 & 960 & N767,000 & E709,000 & Frenchman Flat & -73.4 & -9.5 \\
ST4 & 1,225 & N764,400 & E616,300 & Shoshone Mt. & -86.6 & -11.6 \\
TT3 & 1,400 & N839,200 & E600,300 & Buckboard Mesa & -86.8 & -11.4 \\
ST3 & 1,525 & N787,700 & E617,300 & Shoshone Mt. & -85.6 & -11.7 \\
RT3 & 1,590 & N866,500 & E610,200 & Rainier Mesa & -81.8 & -11.0 \\
TT2 & 1,630 & N836,900 & E582,100 & Timber Mt. & -82.4 & -11.3 \\
ST2 & 1,830 & N797,100 & E621,700 & Shoshone Mt. & -90.4 & -12.4 \\
\hline
\end{tabular}

From these data, assuming that all precipitation collected would enter Frenchman Flat aquifers as recharge, one would expect recent groundwater recharge to be somewhere between -73 and -90 per mil (\%) $\delta \mathrm{D}$ and between -9 and $-12 \%$ o $\delta^{18} \mathrm{O}$. However, it is generally accepted that not all precipitation enters southern Nevada aquifers as recharge and that groundwater recharge occurs mostly from winter precipitation (e.g., Winograd et al., 1998; Hershey, 1989). Ingraham et al. (1990) observed seasonal variations in stable isotopic composition of precipitation at each station on the NTS where winter precipitation was more depleted than summer precipitation.

Ingraham et al. (1990) noted that variations in spring discharge at Whiterock and Cane springs were correlated with large precipitation events, while smaller precipitation events had no effect on spring discharge, suggesting that not all precipitation is recharged. Evaporative enrichment of water was observed at Whiterock and Cane springs and is likely caused by evaporation of impounded water at the spring source. Samples from both springs fall along an enrichment line that intersects the local meteoric water line at about $-13 \% \delta^{18} \mathrm{O}$ and $-97 \%$ o $\delta$, which represents a reasonable value for recharging precipitation (Figure 5).

A comparison of local recent recharge isotopic signature with Frenchman Flat groundwater (Figure 6) shows that most Frenchman Flat groundwater is substantially depleted isotopically relative to local recent recharge. This, coupled with Frenchman Flat groundwater isotopic signatures falling well off both the global meteoric water line (Craig, 1961) and local meteoric water line (Ingraham et al., 1990), suggests that Frenchman Flat groundwater was recharged elsewhere or was recharged under climatic conditions different than today. The only Frenchman Flat groundwater that has a similar isotopic signature to local recent recharge is Water Well \#4 and Water Well 4A in northwest Frenchman Flat in the CP Basin. 


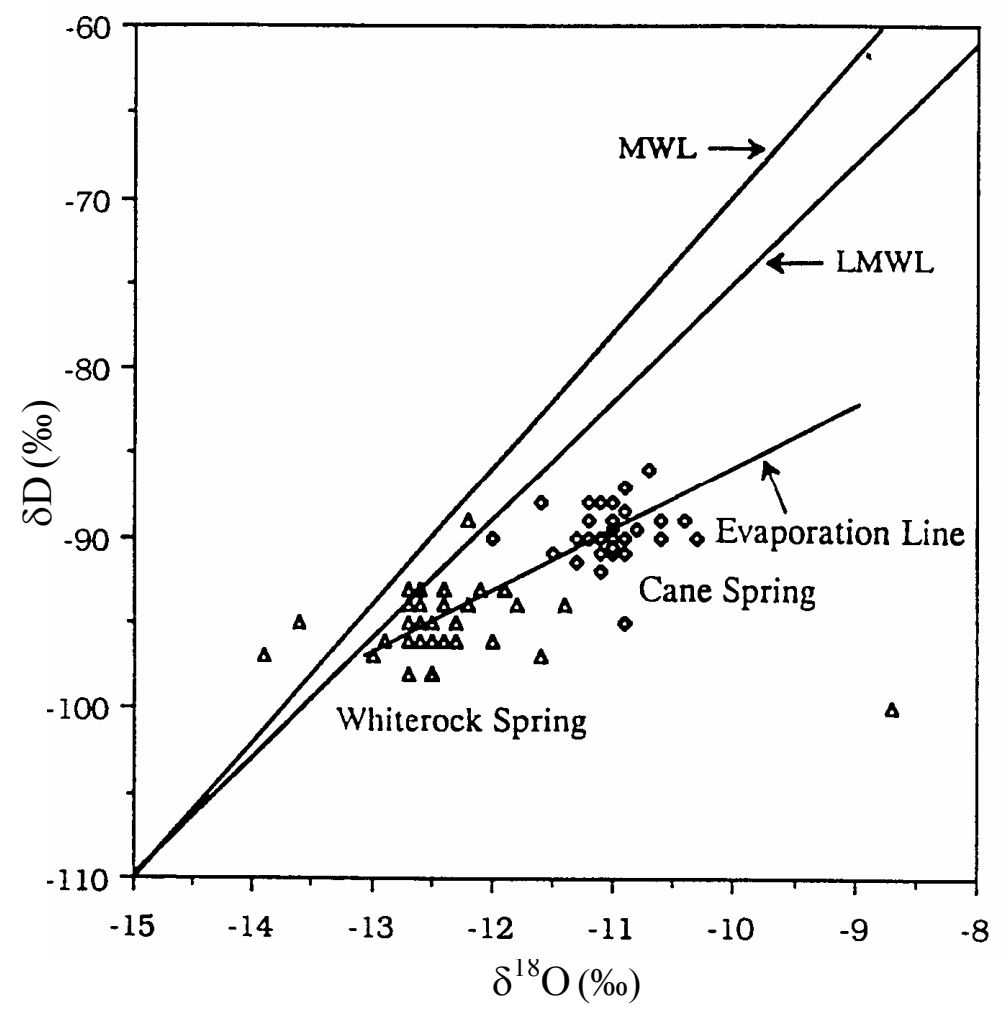

Figure 5. The available $\delta \mathrm{D}$ and $\delta^{18} \mathrm{O}$ of discharge water from Whiterock and Cane springs. Also shown are the meteoric water line (MWL: $\delta \mathrm{D}=8 \delta^{18} \mathrm{O}+10$, Craig, 1961) and a local meteoric water line (LMWL: $\delta \mathrm{D}=6.87 \delta^{18} \mathrm{O}-6.5$, Ingraham et al., 1990). The spring waters plot in two separate fields and appear to have undergone evaporation following an evaporation line as shown (from Ingraham et al., 1990).

\section{Groundwater Geochemistry}

\section{Major-ion Chemistry}

The dissolved constituents in groundwater are a record of the minerals encountered as groundwater moves through an aquifer; thus, water chemistry can be used to trace the movement of groundwater in a hydrologic system. Schoff and Moore (1964), Blankennagel and Weir (1973), and Winograd and Thordarson (1975) identified three hydrochemical facies in and near the NTS. These are a Na-K- $\mathrm{HCO}_{3}$ facies from groundwater in volcanic rocks, a $\mathrm{Ca}-\mathrm{Mg}-\mathrm{HCO}_{3}$ facies in carbonate rocks east and south of the NTS, and a $\mathrm{Ca}-\mathrm{Mg}-\mathrm{Na}-\mathrm{HCO}_{3}$ mixed facies in carbonate rocks beneath the NTS and in the Ash Meadows area. More recently, Chapman and Lyles (1993) compiled water chemistry data from the NTS analyzed by the U.S. Geological Survey (USGS) and Desert Research Institute (DRI) from 1957 through 1990 and reaffirmed the occurrence of these three important hydrochemical facies.

To trace the movement of groundwater in the Frenchman Flat area, samples were collected from six wells in June 2000. Additionally, four new wells were drilled, and samples collected, in 2002 and 2003. Historical groundwater chemical data were also incorporated to complete the data set. These included groundwater-sampling locations with complete 
major-ion and $\delta \mathrm{D}$ and/or $\delta^{18} \mathrm{O}$ analyses from several wells north of Frenchman Flat in southern Yucca Flat, wells and springs east of Frenchman Flat, springs from the Spring Mountains, and wells and springs south and southwest of Frenchman Flat. For sample locations with multiple analyses spanning several years or more, one analysis was selected to represent the water quality of that location. For $\delta \mathrm{D}$ and $\delta^{18} \mathrm{O}$ analyses, an average of all available data was calculated for each sampling location. The sample locations are shown on Figure1 and Figure 7. Chemical data are listed in Appendix A.

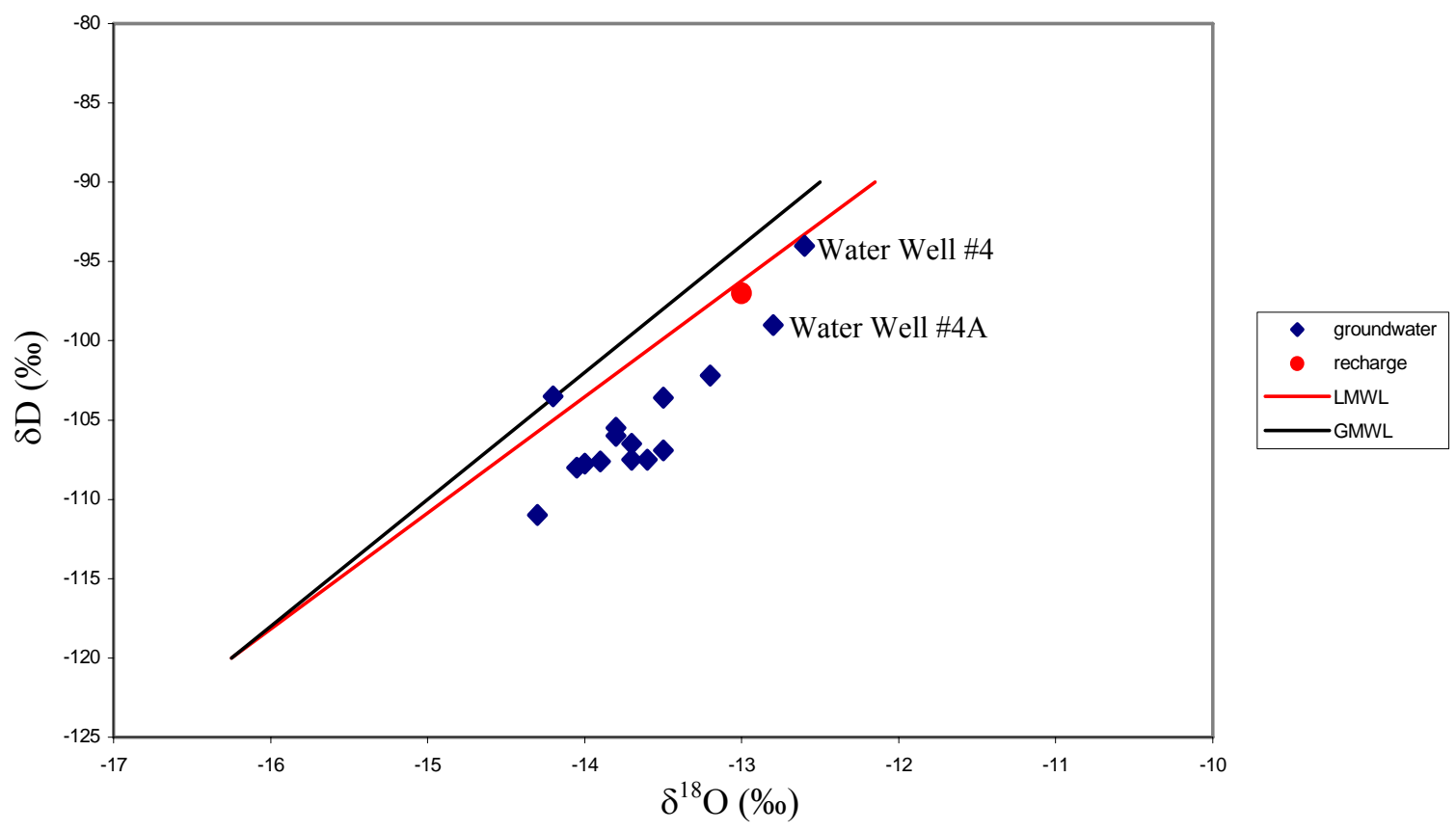

Figure 6. Comparison of the isotopic composition of Frenchman Flat groundwater to recent local recharge (GMWL: $\delta \mathrm{D}=8 \delta^{18} \mathrm{O}+10$, Craig, 1961; LMWL: $\delta \mathrm{D}=6.87 \delta^{18} \mathrm{O}-6.5$, Ingraham et al., 1990).

Dissolved-ion compositions of groundwater in the study area can be categorized into two main types as shown in Figure 8 . The sodium bicarbonate $\left(\mathrm{Na}+\mathrm{K}-\mathrm{HCO}_{3}\right)$ type has approximately 50 percent or greater $\mathrm{Na}+\mathrm{K}$ for the dominant cations, with $\mathrm{Ca}+\mathrm{Mg}$ ranging from 0 to 45 percent, and greater than 50 percent $\mathrm{HCO}_{3}$ for the dominant anions. All of the alluvial- and volcanic-hosted groundwaters in Frenchman Flat are of this category. The calcium-sodium bicarbonate $\left(\mathrm{Ca}+\mathrm{Mg}-\mathrm{Na}-\mathrm{HCO}_{3}\right)$ type has greater than 50 percent $\mathrm{Ca}+\mathrm{Mg}$ for the dominant cations, with $\mathrm{Na}+\mathrm{K}$ ranging from 30 to 50 percent, and 50 percent $\mathrm{HCO}_{3}$ for the dominant anions. All of the carbonate-hosted groundwater in southern Yucca Flat, Frenchman Flat, and south of Frenchman Flat are of this category. These water types are indicative of the major rock types encounter by groundwater. The major-ion chemistry suggests dissolution of feldspar-rich volcanic glass and minerals in the alluvial and volcanic aquifers and mixing of this water with groundwater in the underlying carbonate aquifer, rich in calcite and dolomite (Schoff and Moore, 1964; Blankennagel and Weir, 1973; Winograd and Thordarson, 1975; Chapman and Lyles, 1993). 


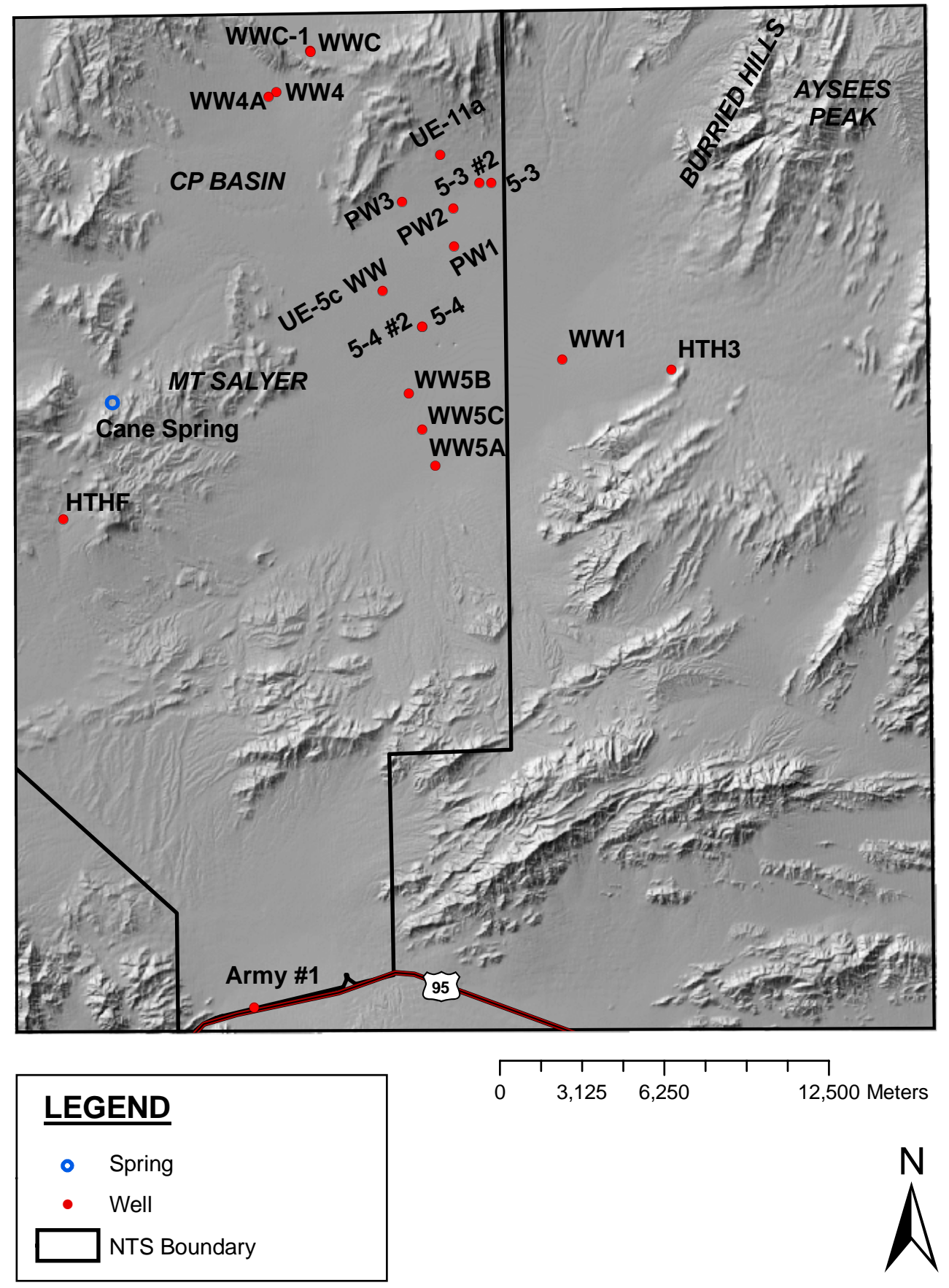

Figure 7. Wells in the Frenchman Flat area. See page viii for a list of abbreviations of well and spring names. 


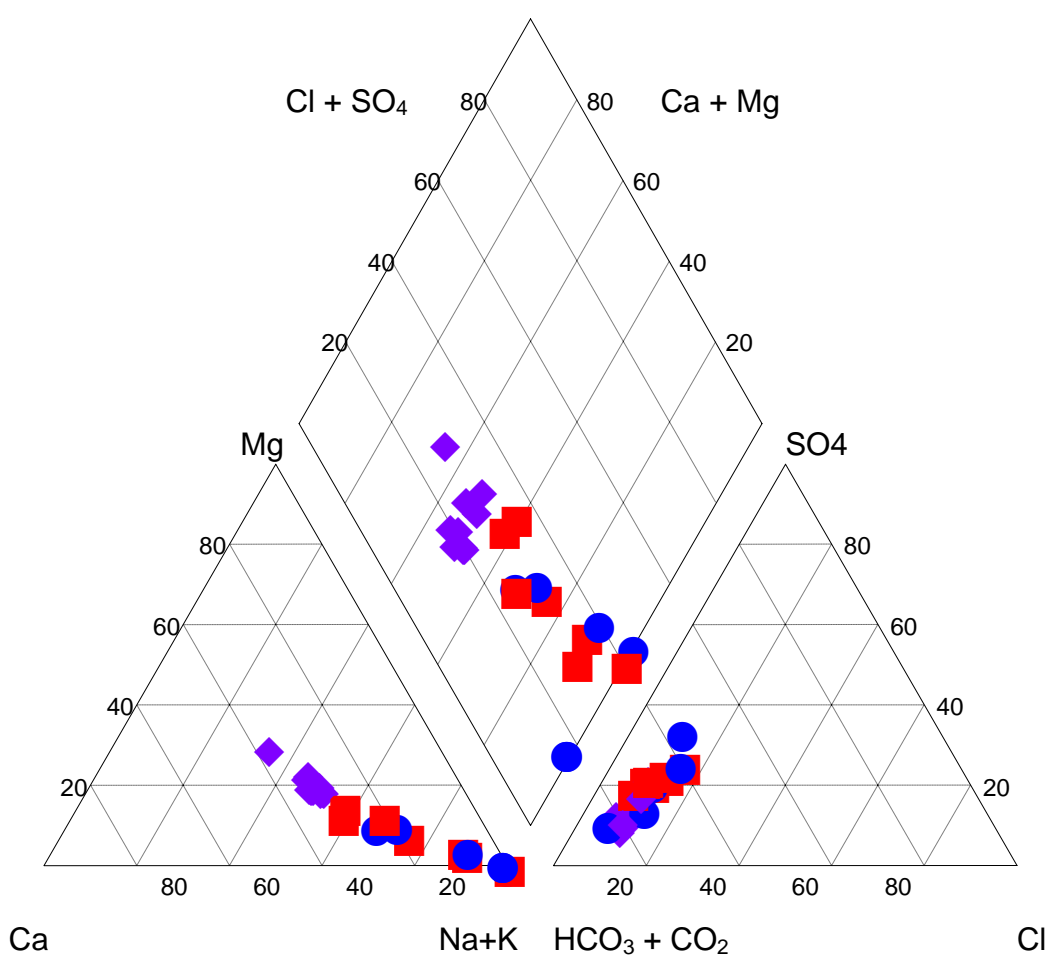

Figure 8. Trilinear diagram showing the proportion of major ions in percent equivalents per million in the alluvial (blue circles), volcanic (red squares), and carbonate (purple diamonds) hydrostratigraphic units in Frenchman Flat and vicinity.

Stiff diagrams, presenting concentrations of major ions in equivalents per million, show differences in total dissolved solids (TDS) in the alluvial aquifer (Figure 9, Table 4). The more dilute groundwater has a TDS of about $250 \mathrm{mg} / \mathrm{L}$ (calculated as total concentration of $\mathrm{Ca}, \mathrm{Mg}, \mathrm{Na}, \mathrm{K}, \mathrm{Cl}, \mathrm{SO}_{4}, \mathrm{SiO}_{2}$ and $1 / 2 \mathrm{HCO}_{3}+\mathrm{CO}_{3}$ ), while less dilute groundwater has a TDS of about $550 \mathrm{mg} / \mathrm{L}$. There does not seem to be a discernible spatial pattern in the major-ion chemistry in the alluvial aquifer. Chapman and Lyles (1993) noted the areal differences in ion concentrations in the alluvial aquifer in Frenchman Flat and suggested that these differences demonstrated a "lack of well-developed lateral flow systems that would homogenize chemical character" within Frenchman Flat. They went on to suggest that this implied that "vertical flow dominates in the alluvium." The lack of the $\mathrm{Ca}+\mathrm{Mg}-\mathrm{Na}-\mathrm{HCO}_{3}$ mixed water in the alluvial aquifer suggests that the north-to-south conceptual model is unlikely since the mixed groundwater found in the southern Yucca Flat LCA would flow into the Frenchman Flat alluvium.

In the volcanic hydrostratigraphic units, similar to groundwater in the alluvium, there are notable differences in TDS (Figure 10). Most of the dilute groundwater samples are about 250 to $290 \mathrm{mg} / \mathrm{L}$ TDS with a couple of samples somewhat higher $(\mathrm{UE}-5 \mathrm{c}$ Water Well $=331 \mathrm{mg} / \mathrm{L}$; $\mathrm{UE}-11 \mathrm{a}=373 \mathrm{mg} / \mathrm{L})$ and one substantially higher $(\mathrm{ER}-5-4 \# 2=763 \mathrm{mg} / \mathrm{L})$. Also similar to the alluvial aquifer, there is no discernible spatial pattern in major-ion chemistry in the volcanic hydrostratigraphic units, suggesting limited lateral flow. As with the alluvial aquifer major-ion composition described above, the lack of the $\mathrm{Ca}+\mathrm{Mg}-\mathrm{Na}-\mathrm{HCO}_{3}$ type groundwater in the volcanic aquifer would discount the north-to-south conceptual model. 
Table 4. Total dissolved solids concentrations for wells in the vicinity of Frenchman Flat.

\begin{tabular}{lcc}
\hline Well & General Rock Type & TDS (mg/L) \\
\hline Amargosa Tracer Well \#2 & carbonate & 426 \\
Army \#1 Water Well & carbonate & 332 \\
ER-3-1 & carbonate & 811 \\
ER-5-3 & volcanic & 272 \\
ER-5-3 \#2 & carbonate & 692 \\
ER-5-4 & alluvium & 579 \\
ER-5-4 \#2 & volcanic & 763 \\
ER-6-1 & carbonate & 298 \\
ER-6-1 \#2 & carbonate & 305 \\
UE-11a & volcanic & 373 \\
UE-5 PW-1 & alluvium & 255 \\
UE-5 PW-2 & alluvium & 246 \\
UE-5 PW-3 & volcanic & 268 \\
UE-5c Water Well & volcanic & 331 \\
USGS HTH \#3 & carbonate & 436 \\
USGS Test Well F & carbonate & 415 \\
USGS Water Well C & carbonate & 663 \\
Water Well 4 & volcanic & 252 \\
Water Well \#4A & volcanic & 291 \\
Water Well 5A & alluvium & 381 \\
Water Well 5B & alluvium & 351 \\
Water Well 5C & alluvium & 401 \\
Water Well C-1 & carbonate & 654 \\
\hline
\end{tabular}

There is only one well in Frenchman Flat that penetrates the LCA, ER-5-3 \#2 (TDS $=692 \mathrm{mg} / \mathrm{L})$. A plot of the depth of the bottom of the open interval of a well with TDS (Figure 11) shows a trend toward higher TDS with depth, at least for the four most recently drilled wells. This trend may be the result of older water having increased water-rock contact time or perhaps the downward movement of groundwater in these areas of Frenchman Flat. Water-level elevations show decreasing hydraulic head with depth for the ER-5-3 well pair (734.55 m amsl for ER-5-3; $727.47 \mathrm{~m}$ amsl for ER-5-3 \#2); however, water-level elevations show an increase in head for the ER-5-4 well pair (731.95 m amsl for ER-5-4; $752.83 \mathrm{~m}$ amsl for ER-5-4 \#2). 
ER-5-4

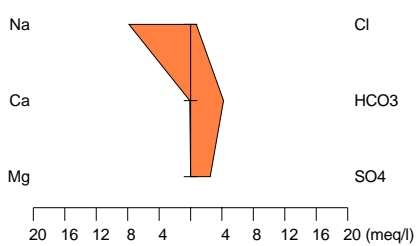

Water Well 5A

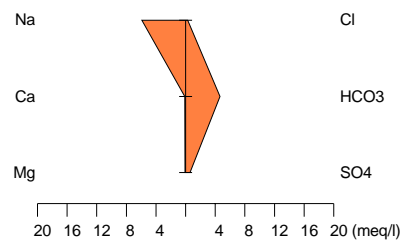

Water Well 5C

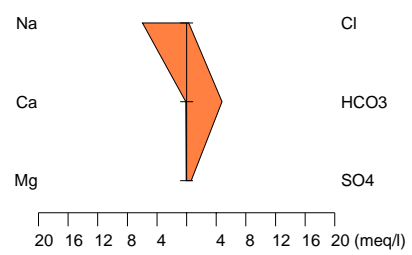

UE-5 PW-1

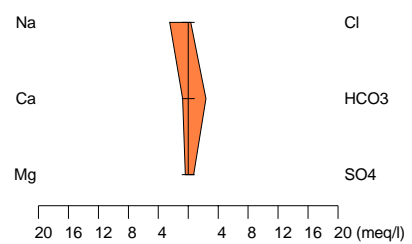

UE-5 PW-2

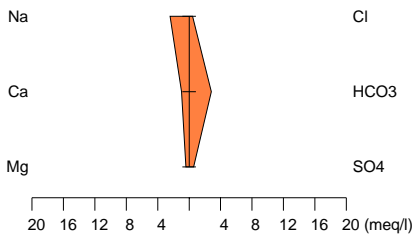

Water Well 5B

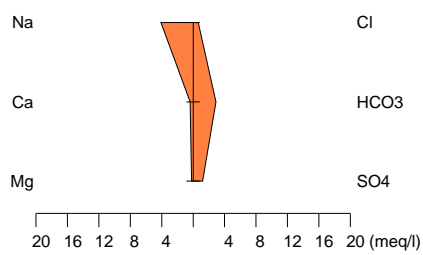

Figure 9. Stiff diagrams showing milliequivalents per liter of major ions in groundwater in the alluvial aquifer in Frenchman Flat. 

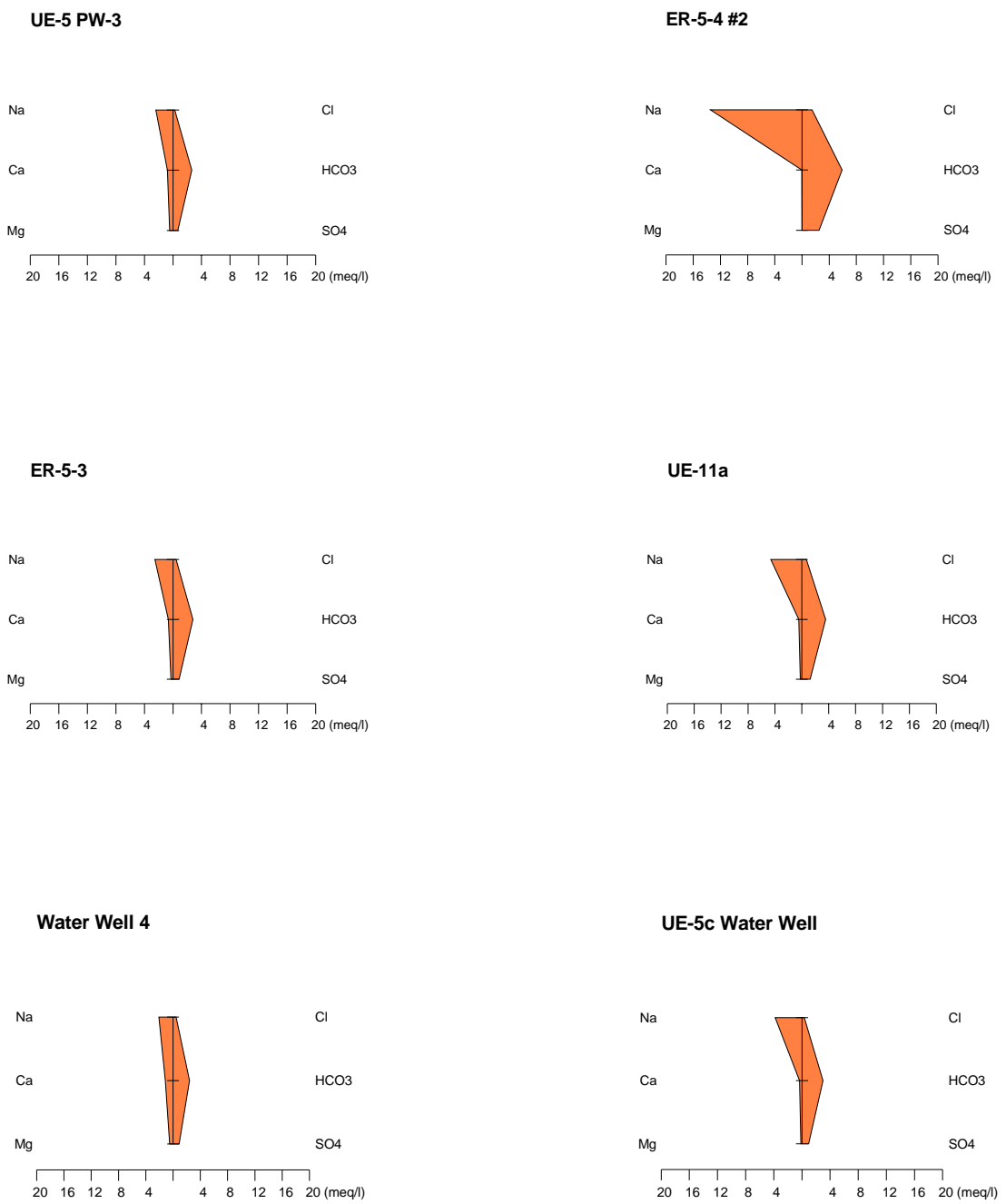

UE-5c Water Well

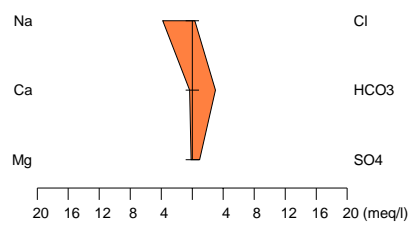

Water Well 4A

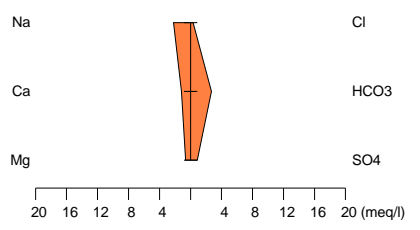

Figure 10. Stiff diagrams showing milliequivalents per liter of major ions in groundwater in the volcanic hydrostratigraphic units in Frenchman Flat. 


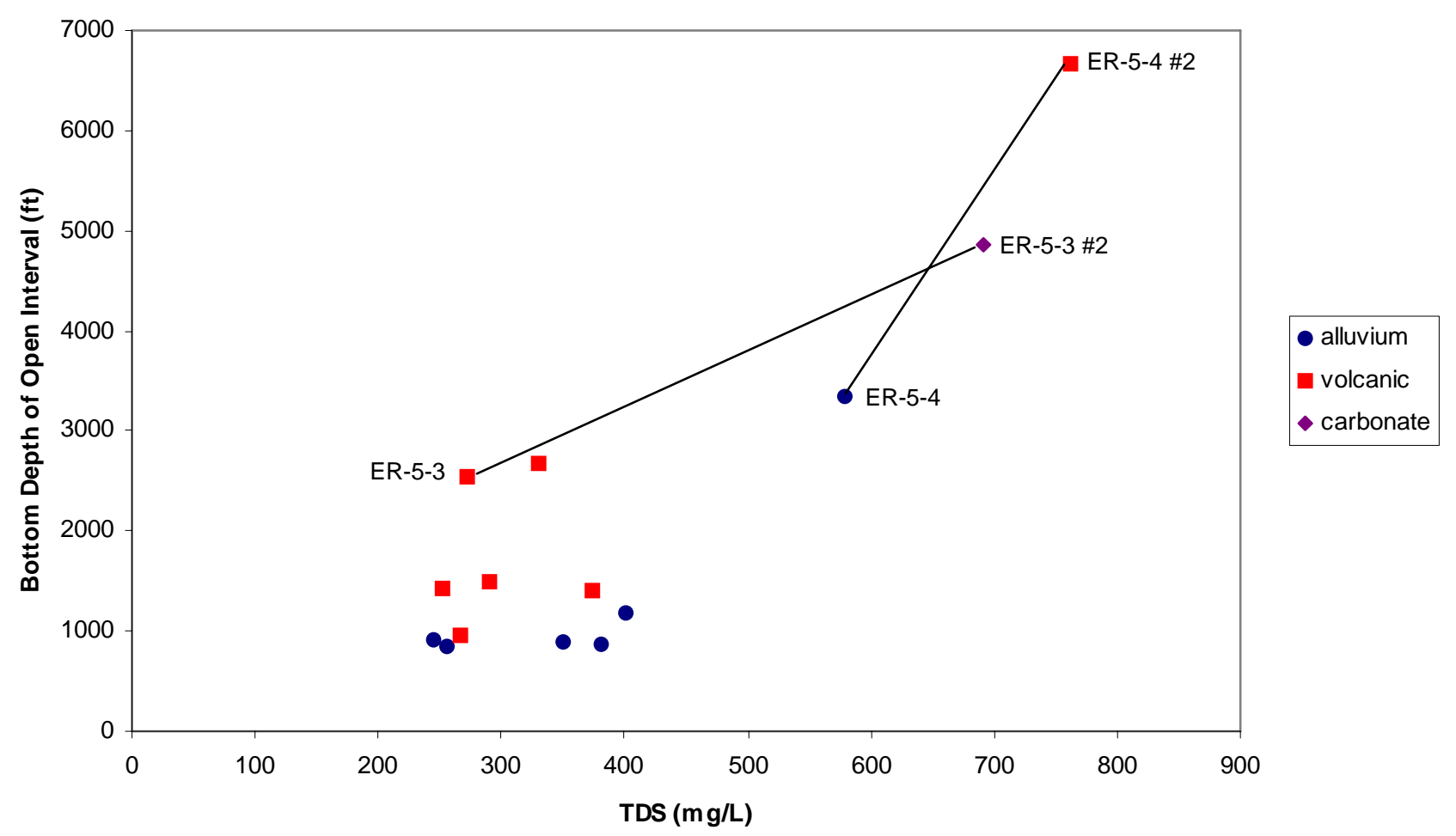

Figure 11. Total dissolved solids in groundwater compared to depth of the bottom of the screened interval in wells in Frenchman Flat. Well pairs ER-5-3/ER-5-3 \#2 and ER-5-4/ER-5-4 \#2 show an increase in TDS with depth.

Since there is only one well in Frenchman Flat that penetrates the LCA and the LCA is thought to be the conduit for transporting radionuclides in groundwater beyond Frenchman Flat (IT, 2001), major-ion chemistry of wells penetrating the LCA surrounding Frenchman Flat was examined (Figure 12). Total dissolved solids concentrations show two distinct groups of water in the LCA near Frenchman Flat, more dilute and less dilute. The more dilute groundwater is found in southern Yucca Flat, considered being upgradient of Frenchman Flat in the LCA, with TDS of about $300 \mathrm{mg} / \mathrm{L}$ (ER-6-1 and ER-6-1 \#2). More dilute carbonate groundwater is also found downgradient of Frenchman Flat to the west, east, and south, where TDS is approximately $400 \mathrm{mg} / \mathrm{L}$ (USGS Test Well "F", USGS HTH \#3, Army \#1 Water Well, Amargosa Tracer Well \#2). The less dilute LCA groundwater is found in southeastern Yucca Flat (ER-3-1, USGS Water Well C, Water Well C-1) and in northern Frenchman Flat (ER-5-3 \#2). In the more dilute groundwater, $\mathrm{Ca}$ and $\mathrm{Na}$ concentrations, expressed as equilivants per liter, are approximately equal, while the less dilute groundwater has more $\mathrm{Na}$ than $\mathrm{Ca}$. 
ER-3-1

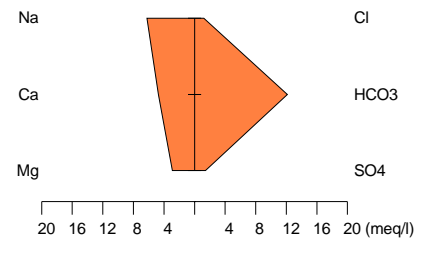

USGS Water Well C
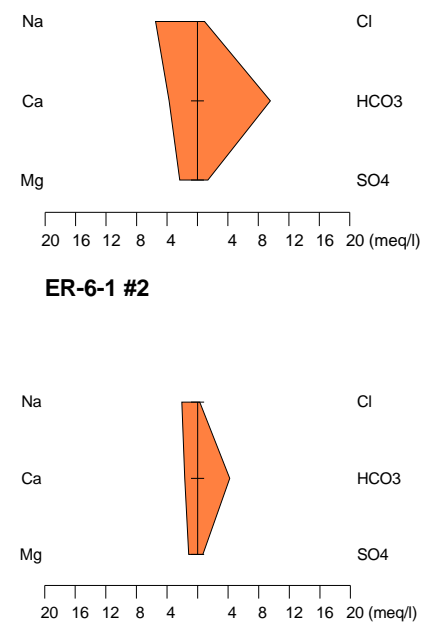

USGS Test Well F

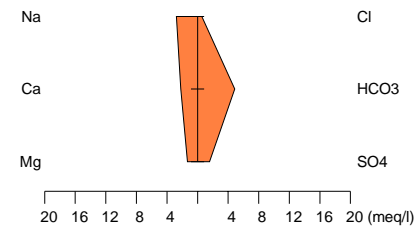

Amargosa Tracer Hole \#2

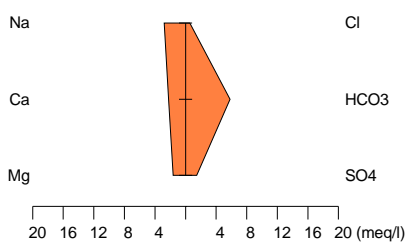

Water Well C-1

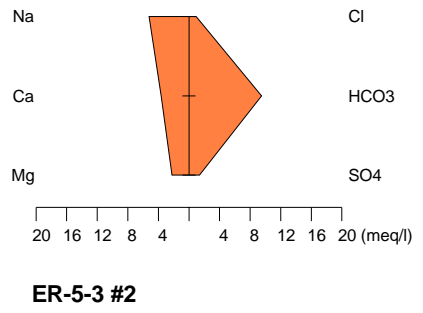

$\mathrm{Na}$

$\mathrm{Ca}$

Mg

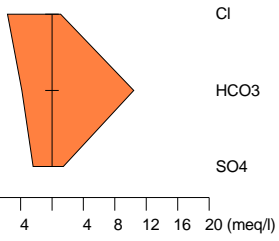

ER-6-1

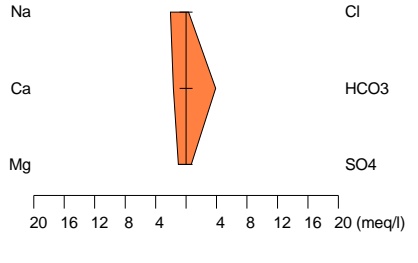

USGS HTH \#3

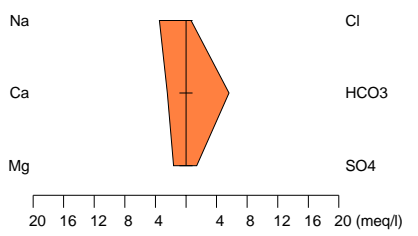

Army \#1 Water Well

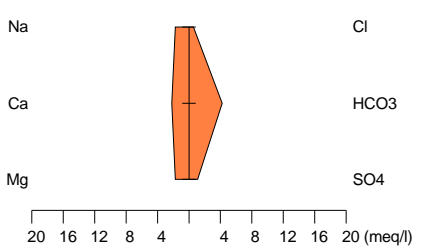

Figure 12. Stiff diagrams showing milliequivalents per liter of major ions in groundwater in the carbonate aquifer in Frenchman Flat. 
The LCA groundwater chemistry suggests at least two possible flowpaths. The first would move dilute LCA groundwater from southern Yucca Flat through Frenchman Flat toward Army \#1 Water Well to the south reacting with aquifer minerals to increase TDS slightly. The other would move less dilute southeastern Yucca Flat groundwater into Frenchman Flat and then at some point downgradient, mixing with more dilute groundwater from the east or southeast, for example, with water from the Spring Mountains, and then toward the south. Downward movement of less dilute alluvial or volcanic groundwaters into the LCA would also be permissible from the major-ion chemistry.

\section{Strontium}

Concentrations of dissolved Sr vary widely in Frenchman Flat groundwater, ranging from about 0.002 to $0.90 \mu \mathrm{g} / \mathrm{g}$ (Appendix A). However, much of this range is attributable to large differences between high $\mathrm{Sr}$ concentrations $(0.8$ to $0.9 \mu \mathrm{g} / \mathrm{g})$ in the LCA samples compared to low concentrations (less than about $0.2 \mu \mathrm{g} / \mathrm{g}$ ) in alluvial and volcanic samples. Strong geochemical affinities between $\mathrm{Sr}$ and $\mathrm{Ca}$ result in a moderately well-defined correlation of concentrations in alluvial and volcanic samples (Figure 13), indicating a moreor-less uniform source of alkali-earth elements over a large area in these aquifers. In addition, samples of the LCA aquifer from ER-6-1 and Indian Springs contain relative $\mathrm{Sr}$ and $\mathrm{Ca}$ concentrations consistent with the $\mathrm{Sr} / \mathrm{Ca}$ trend observed in the shallower Frenchman Flat samples. Low-Sr water samples shown in Figure 13 (excluding Cold Creek and Cane springs) have an average $\mathrm{Sr} / \mathrm{Ca}$ weight ratio of 0.0058 . This ratio is larger than $\mathrm{Sr} / \mathrm{Ca}$ values commonly present in marine carbonates (gray field in Figure 13), which typically vary from 0.0016 to 0.0035 in limestone (Lear et al., 2003) and from 0.00005 to 0.00044 in dolostone (Nader et al., 2004). Strontium/calcium values in stream flow reflect the readily soluble alkali-earth elements from soil carbonate that may contribute to groundwater recharge. Analyses of 21 samples of stream flow obtained across the NTS have $\mathrm{Sr} / \mathrm{Ca}$ from 0.00094 to 0.0072 with a mean of 0.0038 (Savard, 1996; database references).

These data indicate that much of the dissolved $\mathrm{Sr}$ in groundwater from the Frenchman Flat volcanic and alluvial aquifers may be derived from dissolution of carbonate-rich soils. However, addition of alkali-earth elements from a source with higher $\mathrm{Sr} / \mathrm{Ca}$ ratios is likely to explain the higher values observed in shallower Frenchman Flat groundwater. Volcanic rocks of the southwest Nevada volcanic field have wide variations in $\mathrm{Sr} / \mathrm{Ca}$, ranging from about 0.0021 to 0.046 for mid-Tertiary volcanic rocks at Yucca Mountain (data from Peterman et al., 1993, 1996; Peterman and Futa, 1996; Peterman and Cloke, 2002). Dissolution of silicate constituents (particularly glassy units in the Tertiary volcanic aquifer and alluvial aquifers) likely contributes $\mathrm{Sr}$ to groundwater in these shallower aquifers. Addition of $\mathrm{Sr}$ from silicate sources appears to be absent in water samples with relatively short flow lengths (Cane Spring, Cold Creek Spring, Tipipah Spring, UE-29a \#1, UE-29a \#2) where values of Sr/Ca (0.0011 to 0.0036, this report and Thomas et al., 2002) are more similar to values observed in stream flow rather than groundwater in the shallower aquifers in Frenchman Flat. Sorption of alkaliearth elements onto aquifer rock surfaces (particularly zeolitized tuff) is an effective means of removing both $\mathrm{Ca}$ and $\mathrm{Sr}$ from solution but will not cause large fractionation between the two geochemically similar elements.

Groundwater samples from the LCA in the Frenchman Flat vicinity have Ca concentrations higher than samples of groundwater from the volcanic and alluvial aquifers and similar to those observed in the LCA samples from Indian Springs Valley. However, Sr 
concentrations are substantially higher (Figure 13). Strontium/calcium ratios range from 0.010 for ER-3-1 to 0.018 for USGS HTH \#3 and Army \#1 Water Well. Lower Carbonate Aquifer samples show an apparent increase in $\mathrm{Sr} / \mathrm{Ca}$ from north to south in the Frenchman Flat vicinity. Notably, water samples from both Army \#1 Water Well and Ash Meadows discharge show strong affinities in Sr concentration with Frenchman Flat LCA samples rather than with water from the Indian Springs LCA samples. Water samples with intermediate $\mathrm{Sr}$ concentrations have not been identified in this area. As noted above, dissolved Sr contents of Frenchman Flat LCA groundwater as well as Army \#1 Water Well or Ash Meadows discharge cannot be derived through bulk dissolution of LCA host rock with marine carbonate $\mathrm{Sr} / \mathrm{Ca}$ ratios.

Differences observed in groundwater Sr concentrations are also reflected in ${ }^{87} \mathrm{Sr} /{ }^{86} \mathrm{Sr}$ ratios (Figure 14). Low-Sr samples from the alluvial and volcanic aquifers have ${ }^{87} \mathrm{Sr} /{ }^{86} \mathrm{Sr}$ values ranging from 0.70884 to 0.71116 . These values are lower than those typical of the $\mathrm{Sr}$ in southern Nevada soil deposits, which vary from 0.711 to 0.713 in the Yucca Mountain vicinity (Marshall and Mahan, 1994). As with $\mathrm{Sr} / \mathrm{Ca}$ results described above, lower ${ }^{87} \mathrm{Sr} /{ }^{86} \mathrm{Sr}$ values in groundwater from Frenchmen Flat alluvial and volcanic aquifers are consistent with the addition of $\mathrm{Sr}$ derived from Sr-rich volcanic-rock sources commonly containing values between 0.708 and $\sim 0.710$ (Peterman and Futa, 1996; Peterman et al., 1996).

Low-Sr water samples from the LCA in Indian Springs Valley have ${ }^{87} \mathrm{Sr} /{ }^{86} \mathrm{Sr}$ values of 0.70878 to 0.71028 (U.S. Geological Survey, unpublished data). These values are only slightly larger than values expected for unaltered Paleozoic marine carbonate rocks of 0.7075 to 0.7090 (Peterman et al., 1970; Burke et al., 1982). In contrast, high-Sr water samples from the LCA in Frenchman Flat have substantially larger ${ }^{87} \mathrm{Sr} /{ }^{86} \mathrm{Sr}$ values, between 0.71328 and 0.71826. These values are more similar to ratios present in samples of Eleana Formation argillite (0.715 to 0.724 , U.S. Geological Survey, unpublished data) than ratios expected for LCA host rock. Strontium-87/strontium-86 values in these samples show a general decrease from the highest values north of Frenchman Flat (ER-3-1), intermediate values in southern Yucca Flat and northern Frenchman Flat (ER-5-3 \#2 and USGS Water Well C and Water Well C-1), and the lowest values in southeastern Frenchman Flat (USGS HTH \#3). Low-Sr samples from the ER-6-1 wells in eastern Yucca Flat have ${ }^{87} \mathrm{Sr} /{ }^{86} \mathrm{Sr}$ intermediate between volcanic aquifers and LCA samples (0.71291 and 0.71296). Samples of the LCA farther to the south at Army \#1 Water Well and a number of discharge sites in Ash Meadows have ${ }^{87} \mathrm{Sr} /{ }^{86} \mathrm{Sr}$ values that are intermediate between those observed for southern Frenchman Flat and Indian Springs samples.

Although water/rock reactions involving dissolution of mineral phases or cation exchange along groundwater flowpaths can modify the ${ }^{87} \mathrm{Sr} /{ }^{86} \mathrm{Sr}$ values, in advecting groundwater, comparisons of ${ }^{87} \mathrm{Sr} /{ }^{86} \mathrm{Sr}$ and more conservative tracers $(\mathrm{Cl}, \delta \mathrm{D})$ in samples from Frenchman Flat aquifers show variations that may reveal information about distinct sources of water and patterns of groundwater flow. Most water samples from Frenchman Flat alluvial and volcanic aquifers have a relatively narrow range of ${ }^{87} \mathrm{Sr} /{ }^{86} \mathrm{Sr}$ values compared to the wider ranges of both $\mathrm{Cl}$ concentration and $\delta \mathrm{D}$ values (Figure 15). Correlations between these more conservative constituents and ${ }^{87} \mathrm{Sr} /{ }^{86} \mathrm{Sr}$ in samples from either the alluvial or volcanic aquifers group are not apparent from visual observation or from regression analysis. Furthermore, no systematic variations in ${ }^{87} \mathrm{Sr} /{ }^{86} \mathrm{Sr}$ with geographic distribution are observed. 


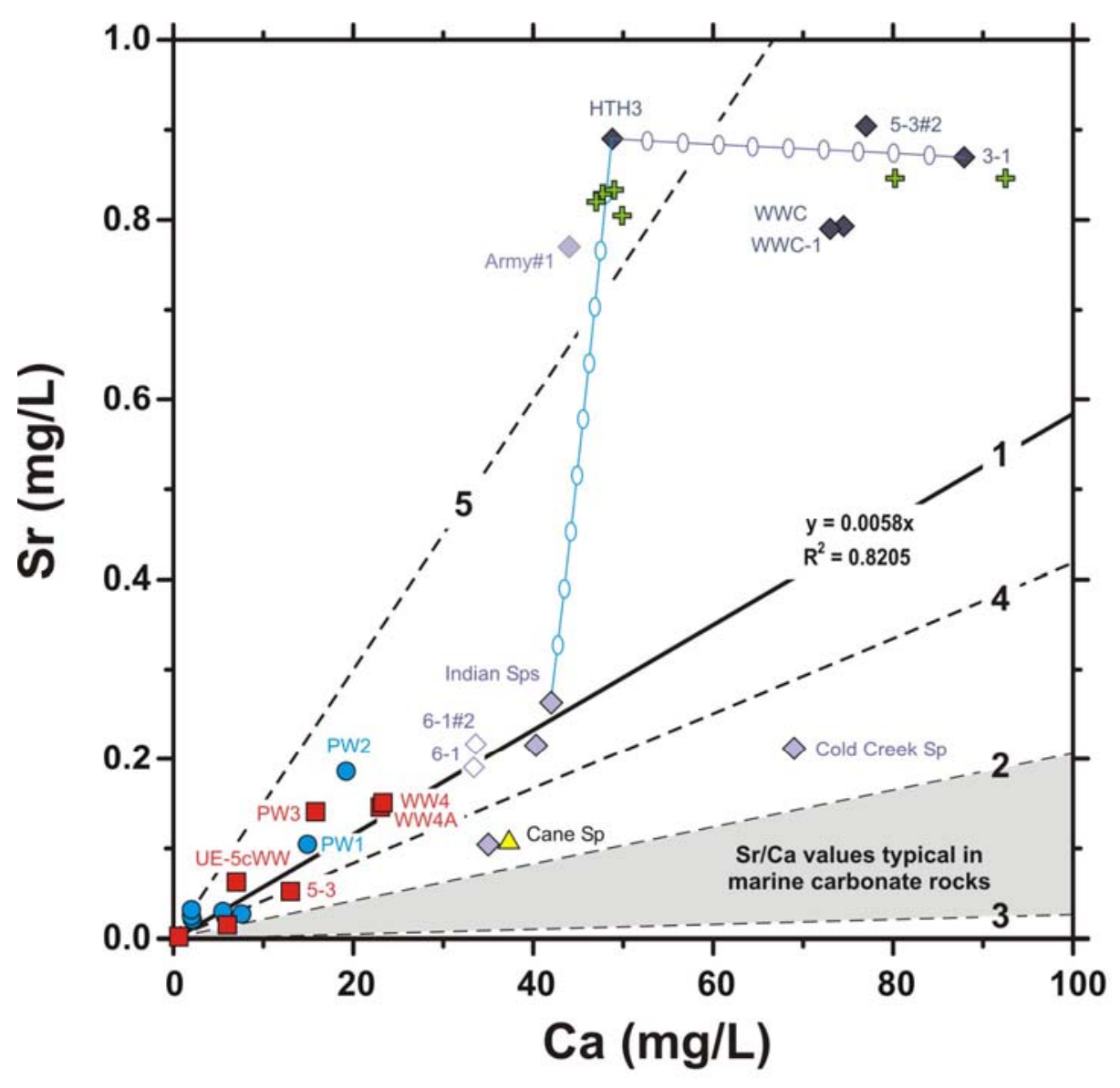

\footnotetext{
Lower Carbonate Aquifer - Frenchman Flat

Lower Carbonate Aquifer - ER-6-1

Lower Carbonate Aquifer - Indian Springs Valley

Tertiary Volcanic Aquifer - Frenchman Flat

- Alluvial Aquifer - Frenchman Flat

$\triangle$ Local Recharge - Southern NTS

\& Ash Meadows Discharge
}

\section{$\mathrm{Sr} / \mathrm{Ca}$ for potential reservoirs contributing to Frenchman Flat groundwater}

1) Regression of low-Sr groundwater samples in this report

2) Mean $\mathrm{Sr} / \mathrm{Ca}$ value for 58 Cenozoic seawater carbonates (Lear et al., 2003)

3) Mean $\mathrm{Sr} / \mathrm{Ca}$ value for 36 Jurassic dolostones (Nader et al., 2004)

4) Mean Sr/Ca value in 16 samples of Nevada Test Site ephemeral streamflow representing soil carbonate (Savard, 1996; USGS unpublished data)

5) Mean $\mathrm{Sr} / \mathrm{Ca}$ value for 84 analyses of Miocene felsic volcanic rocks from Yucca Mountain (Peterman et al., 1993, 1996;

Peterman and Futa, 1996; Peterman and Cloke, 2002)

Figure 13. Concentrations of $\mathrm{Sr}$ and $\mathrm{Ca}$ in selected groundwater samples in the Frenchman Flat vicinity. See page viii for a list of abbreviations of well and spring names. 


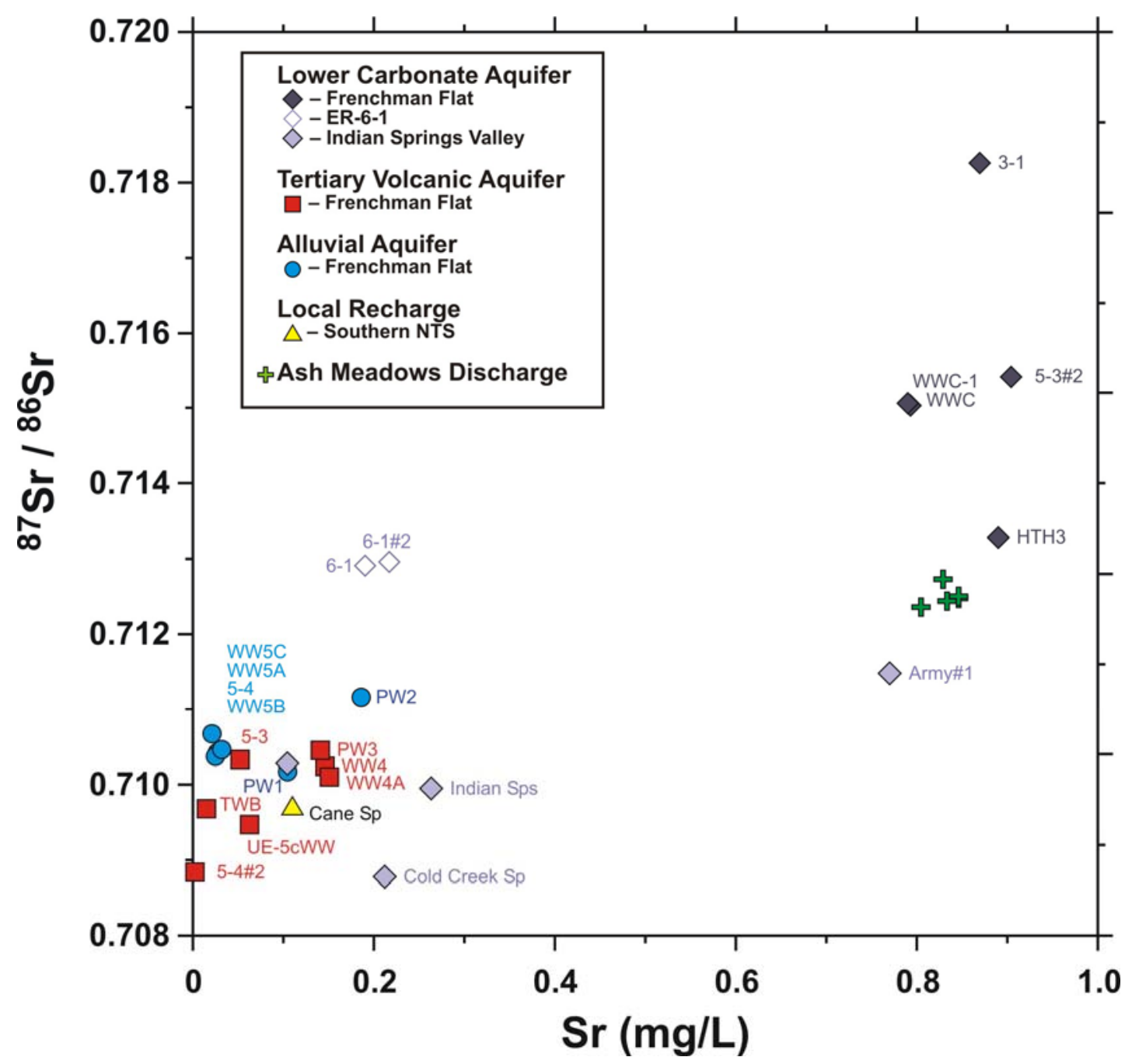

Figure 14. ${ }^{87} \mathrm{Sr} /{ }^{86} \mathrm{Sr}$ ratios and $\mathrm{Sr}$ concentrations for selected water samples in the Frenchman Flat vicinity. See page viii for a list of abbreviations of well and spring names. 

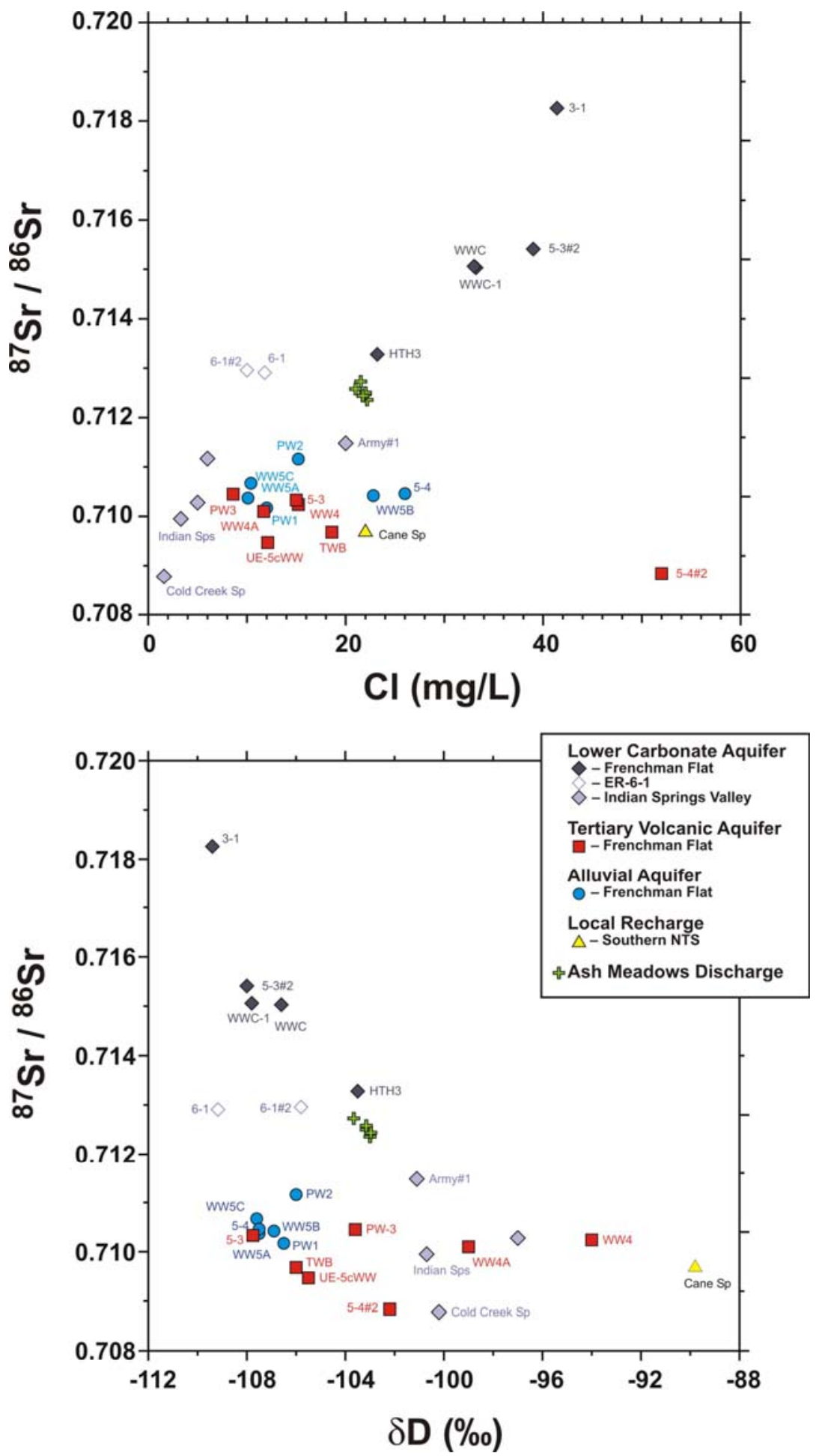

Figure 15. Relations between ${ }^{87} \mathrm{Sr} r{ }^{86} \mathrm{Sr}, \mathrm{Cl}$ concentrations, and $\delta \mathrm{D}$ for selected water samples in the Frenchman Flat vicinity. See page viii for a list of abbreviations of well and spring names.

In contrast, samples of the Frenchman Flat LCA show crude correlations with both $\mathrm{Cl}$ and $\delta \mathrm{D}$ (Figure 15). Compositional trends defined by Frenchman Flat LCA samples are 
clearly distinct from those observed in LCA samples from Indian Springs Valley in terms of both ${ }^{87} \mathrm{Sr} /{ }^{86} \mathrm{Sr}$ and conservative tracer contents. As noted above, compositions for Army \#1 Water Well and Ash Meadows discharge are intermediate between trends observed for Frenchman Flat LCA and Indian Springs LCA samples.

\section{Conservative Tracer Modeling}

The quantitative geochemical evaluation of groundwater flow systems typically begins with an assessment of the most conservative (nonreactive) species (see Benedict et al., 2003). Stable isotopes intrinsic to the water molecule $\left(\delta \mathrm{D}\right.$ and $\delta^{18} \mathrm{O}$ ) and dissolved $\mathrm{Cl}$ are considered to be the most conservative geochemical tracers. In some systems, dissolved $\mathrm{SO}_{4}$ may also behave conservatively, although in the case of Frenchman Flat, $\mathrm{SO}_{4}$ appears not to be conservative.

Conservative tracers can provide valuable insight into potential groundwater pathways and mixing processes. Graphical methods are commonly used to identify mixing trends. More precise mixing ratios are then estimated mathematically, following the method outlined in Rose et al. (2002). The conceptual flowpaths identified using this approach are then tested using independent data and chemical models to determine whether a consistent set of geochemical processes can describe all or most of the data.

\section{Evaluation of Conservative Tracers in Frenchman Flat}

The data analysis strategy first envisioned for this study involved an assessment of the three conceptual flow models presented in IT (2001). These include north-to-south flow, west-to-east flow, and the bathtub model (vertical leakage from the alluvium to the LCA). The ability to analyze these conceptual flowpaths using geochemical data is limited by two factors: (1) existing wells are not evenly distributed geographically within the study area, and (2) there is a significant paucity of wells completed in the LCA, both within the Frenchman Flat basin and to the south of the basin (Table 5). Plots of $\delta \mathrm{D}$ versus $\delta^{18} \mathrm{O}$ (Figure 16) and $\mathrm{Cl}$ versus $\delta^{18} \mathrm{O}$ (Figure 17) were used to make a preliminary analysis of the conceptual flow models. Note that groundwater-mixing trends would be linear on both plots.

North-to-south Flow

The north-to-south flowpath within the alluvial aquifer is perhaps most readily evaluated because the greatest density of wells in Frenchman Flat is located along an approximate north-south trend extending from the northeast part of Area 5 to south of the Frenchman Playa (Figure 7). Although water levels tend to decrease toward the south, a systematic variation in the conservative tracer data is not evident. For example, the two southernmost wells (Water Well 5A and Water Well 5C) contain lower $\mathrm{Cl}$ concentrations than the wells that lie upgradient. Chloride values should either remain constant or increase slightly along a flowpath unless groundwater mixing dilutes the water. On a $\mathrm{Cl}$ versus $\delta^{18} \mathrm{O}$ graph (Figure 17), a suitable dilution component is not apparent unless it is assumed that groundwater recharge from the Spring Mountains can flow into southern Frenchman Flat. On the basis of water level and structural data, Winograd and Thordarson (1975) did not consider this scenario to be likely. In addition, mixing with groundwater from the Spring Mountains would require Water Wells $5 \mathrm{~A}$ and $5 \mathrm{C}$ to increase in $\delta \mathrm{D}$ relative to other alluvial groundwaters in Frenchman Flat (Figure 16), but this is clearly not observed. Hence, we can probably reject this particular model. 
Table 5. Well completion and hydraulic head data for wells located in Frenchman Flat and vicinity.

\begin{tabular}{|c|c|c|c|c|c|c|c|c|}
\hline Well name & $\begin{array}{c}\text { Surface } \\
\text { Elevation } \\
(\mathrm{m})\end{array}$ & $\begin{array}{c}\text { Well } \\
\text { Depth } \\
\text { (m bgs) }\end{array}$ & $\begin{array}{c}\text { Open Interval } \\
(\mathrm{m} \text { bgs })\end{array}$ & $\begin{array}{l}\text { Water } \\
\text { Depth } \\
\text { (m bgs) }\end{array}$ & $\begin{array}{c}\text { Mean SWL } \\
\text { Elevation } \\
(\mathrm{m} \text { amsl })\end{array}$ & $\begin{array}{c}\text { Primary } \\
\text { HSU }\end{array}$ & Water Level Source & $\begin{array}{c}\text { Water Level } \\
\text { Date }\end{array}$ \\
\hline \multicolumn{9}{|l|}{ Frenchman Flat and vicinity } \\
\hline Amargosa Tracer Well \#2 & 731.6 & 252.4 & $236.2-252.4$ & 11.97 & 719.61 & LCA & Johnson (1986) & $11 / 21 / 1966$ \\
\hline Army \#1 Water Well & 961.13 & 595.3 & $243.8-593.1$ & 239.89 & 721.24 & LCA & nevada.usgs.gov & $8 / 16 / 2004$ \\
\hline USGS Test Well F & $1,262.8$ & $1,036.3$ & $960.1-1,036.3$ & 533.7 & 729.1 & LCA & US DOE (1997) & \\
\hline Water Well 5A & 942.63 & 277.4 & $195.7-267.3$ & 216.32 & 726.31 & AA & nevada.usgs.gov & $6 / 28 / 2004$ \\
\hline Water Well 5C & 939.24 & 365.8 & 270.4-361.8 & 219.13 & 720.11 & AA & nevada.usgs.gov & 8/31/1993 \\
\hline Water Well 5B & 942.48 & 274.3 & $213.4-274.3$ & 209.35 & 733.13 & AA & nevada.usgs.gov & $7 / 6 / 2004$ \\
\hline USGS HTH \#3 & $1,061.96$ & 564.8 & $363.6-566.9$ & 336.44 & 725.52 & LCA & nevada.usgs.gov & $1 / 22 / 2002$ \\
\hline Water Well 1 & 944.9 & 265.2 & $217.6-244.4$ & 217.6 & 727.3 & AA & US DOE (1997) & \\
\hline ER-5-4 & 953.11 & $1,137.5$ & $539.5-644.0,955.9-1,021.1$ & 221.16 & 731.95 & AA & nevada.usgs.gov & $6 / 28 / 2004$ \\
\hline ER-5-4 \#2 & 953.11 & $2,113.6$ & $1976.9-2029.4$ & 200.28 & 752.83 & Tcb & nevada.usgs.gov & $6 / 28 / 2004$ \\
\hline UE-5c Water Well & 980.2 & 817.5 & $335.3-817.5$ & 245.7 & 734.5 & WVCU & US DOE (1997) & \\
\hline UE-5 PW-1 & 968.73 & 255.7 & $235.3-255.7$ & 235.06 & 733.67 & AA & nevada.usgs.gov & $4 / 6 / 1993$ \\
\hline UE-5 PW-2 & 989.54 & 280.4 & $256.3-280.4$ & 256.06 & 733.48 & AA & nevada.usgs.gov & $4 / 6 / 1993$ \\
\hline UE-5 PW-3 & $1,004.51$ & 291.1 & $271.6-291.1$ & 271.09 & 733.42 & TMA & nevada.usgs.gov & $4 / 6 / 1993$ \\
\hline ER-5-3 & $1,017.24$ & 794.3 & $451.1-529.4,737.6-776.9$ & 282.69 & 734.55 & AA; TMA & nevada.usgs.gov & $6 / 28 / 2004$ \\
\hline ER-5-3 \#2 & $1,017.24$ & $1,732.2$ & $1,425.9-1,483.8$ & 289.77 & 727.47 & LCA & nevada.usgs.gov & $6 / 28 / 2004$ \\
\hline UE-11a & $1,078.4$ & 426.7 & $347.8-426.7$ & 345.0 & 733.4 & TMA & US DOE (1997) & \\
\hline Water Well \#4A & $1,099.11$ & 462.4 & $287.7-457.8$ & 255.92 & 843.19 & TMA & nevada.usgs.gov & $7 / 6 / 2004$ \\
\hline Water Well 4 & $1,097.74$ & $1,479.0$ & $942-1,435$ & 255.76 & 841.98 & TMA & nevada.usgs.gov & $7 / 6 / 2004$ \\
\hline \multicolumn{9}{|l|}{ Southern Yucca Flat } \\
\hline Water Well C-1 & $1,196.0$ & 520.3 & $469.4-502.9$ & 470.6 & 725.4 & LCA & US DOE (1997) & \\
\hline USGS Water Well C & $1,196.0$ & 518.5 & $475.5-495.0$ & 470.0 & 726.0 & LCA & US DOE (1997) & \\
\hline USGS Test Well B & $1,198.42$ & 510.5 & $436.5-504.7$ & 458.57 & 739.85 & TPTA & nevada.usgs.gov & $6 / 24 / 2004$ \\
\hline ER-6-1 \#2 & $1,199.49$ & 975.4 & $541.0-975.4$ & 470.89 & 728.60 & LCA & nevada.usgs.gov & $9 / 24 / 2003$ \\
\hline ER-6-1 & $1,200.07$ & 648.9 & $554.4-648.9$ & 471.40 & 728.67 & LCA & nevada.usgs.gov & $3 / 31 / 2004$ \\
\hline ER-3-1 & $1,343.17$ & 855.6 & 765.7-793.7 & 614.47 & 728.70 & LCA & nevada.usgs.gov & $6 / 26 / 1995$ \\
\hline
\end{tabular}

AA $=$ Alluvial Aquifer

TMA $=$ Timber Mtn Aquifer

TPTA $=$ Topopah Springs Tuff Aquifer

Tcb $=$ Bullfrog Tuff

WTA $=$ Welded Tuff Aquifer

WVCU $=$ Wahmonie Volcanic Confining Unit

LCA $=$ Lower Carbonate Aquifer 


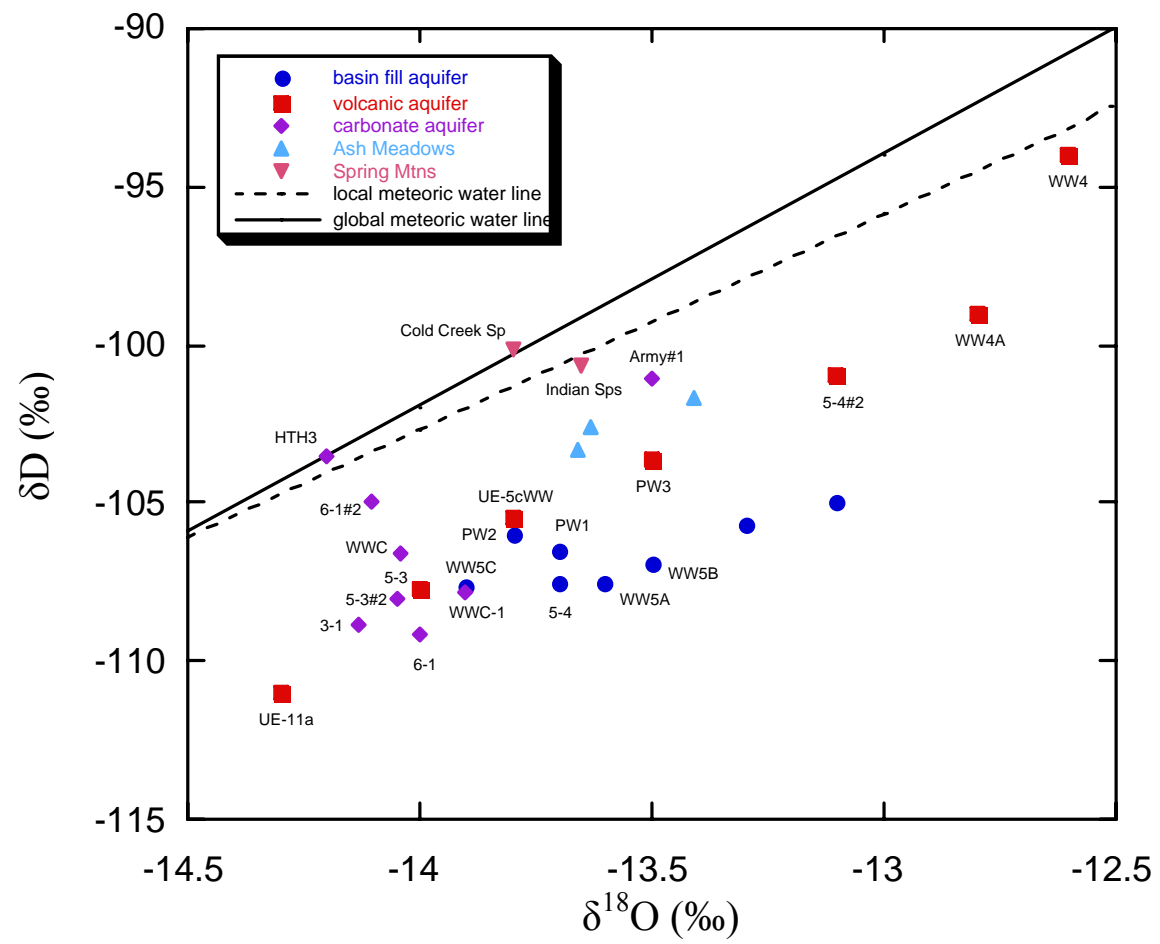

Figure 16. Plot of $\delta \mathrm{D}$ versus $\delta^{18} \mathrm{O}$ values for groundwater from Frenchman Flat and vicinity. See page viii for a list of abbreviations of well and spring names.

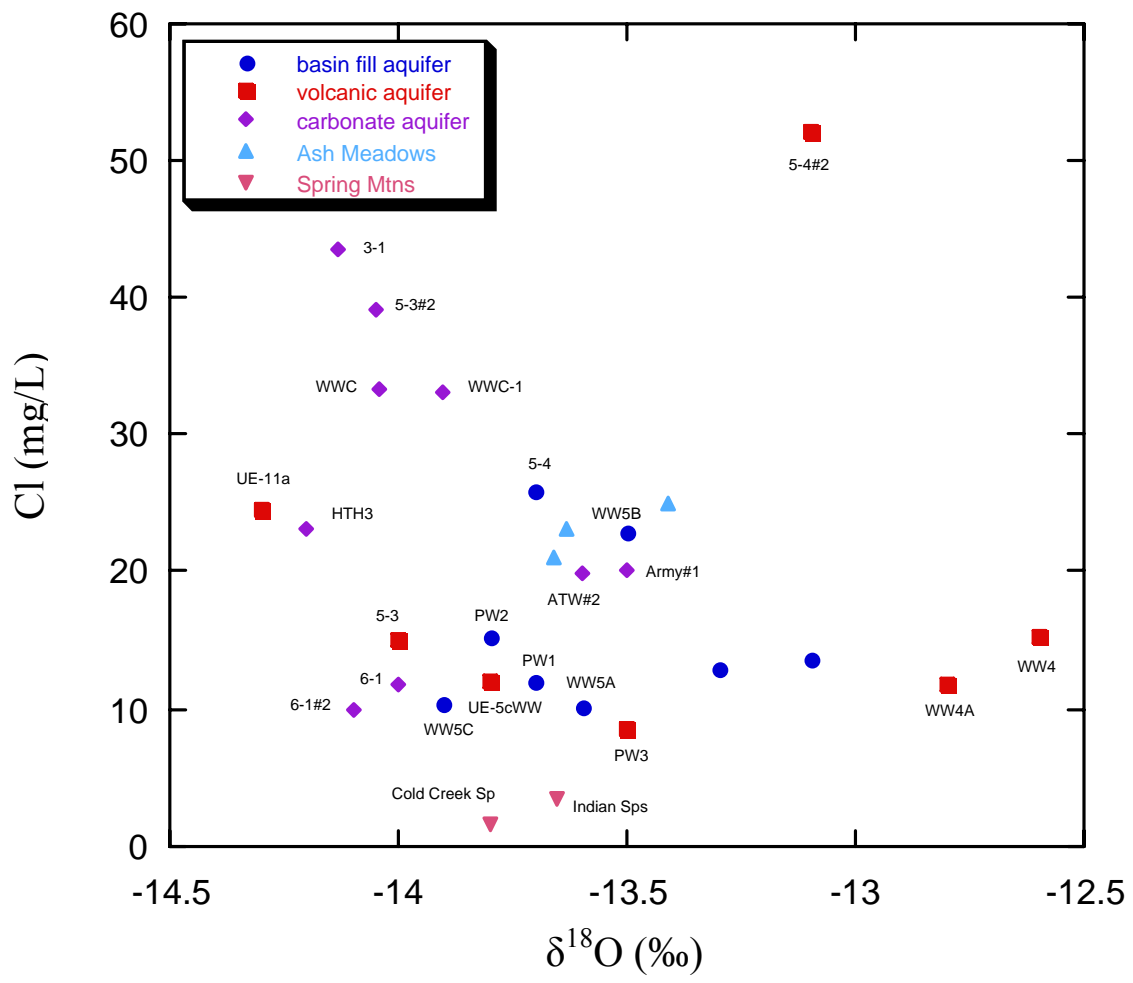

Figure 17. Plot of $\mathrm{Cl}$ concentrations versus $\delta^{18} \mathrm{O}$ values for groundwater from Frenchman Flat and vicinity. See page viii for a list of abbreviations of well and spring names. 
The extrapolation of flowpaths southward out of Frenchman Flat requires us to develop geochemical models for Army \#1 Water Well - the nearest well to the south along the inferred pathway to Ash Meadows. Our analysis of the conservative tracer data (e.g., Figure 16) reveals that Army \#1 Water Well does not fall on a trend with any of the alluvial groundwater samples from Frenchman Flat. Hence, the existing data do not substantiate a north-to-south pathway from the alluvial aquifer to the LCA south of Frenchman Flat. We will consider other possible models involving southward pathways within the LCA later in the discussion.

It is worth noting that $\delta \mathrm{D}, \delta^{18} \mathrm{O}$, and $\mathrm{Cl}$ data all yield a consistent mixing model for Army \#1 Water Well involving 66 to 73 percent Indian Springs (recharge from Spring Mountains) and 27 to 34 percent ER-5-4 \#2. The latter is the deepest well in Frenchman Flat, producing high $\mathrm{Na}-\mathrm{HCO}_{3}-\mathrm{SO}_{4}$ groundwater from a volcanic aquifer approximately $1,981 \mathrm{~m}$ below the surface. This model is intriguing because previous studies predicted similar mixing ratios for groundwater in these geographic areas (cf. Winograd and Friedman, 1972; Thomas et al., 1996). If this model were found to be consistent with other chemical data, it might imply a relatively deep lateral pathway through the volcanic aquifers beneath Frenchman Flat.

West-to-east Flow

The conceptual model involving west-to-east groundwater flow from the alluvial aquifer to the LCA in eastern Frenchman Flat was more difficult to evaluate because there are fewer wells that lie along this trend. Mixing scenarios using conservative tracer data to model the composition of USGS HTH \#3 in eastern Frenchman Flat were completely unsuccessful. This is in large part because USGS HTH \#3 has an unusual $\delta \mathrm{D}-\delta^{18} \mathrm{O}$ pair compared to most groundwater in this region, plotting on the meteoric water line (Figure 16). As a result, there were no pathways or mixing models identified to account for this composition as an end product of west-to-east flow.

Water Well 1 is the easternmost well completed in the alluvial aquifer, but models could not be developed for this site because of a lack of stable isotope data. It should be noted, however, that Water Well 1 groundwater contains only $6 \mathrm{mg} / \mathrm{L} \mathrm{Cl}$ - much less than expected at the downgradient end of the proposed flowpath. This observation does not necessarily negate the west-to-east path, but does call into question the likelihood that Water Well 1 is linked to such a flow system. All wells that lie to the west of Water Well 1 in Frenchman Flat contain more than $6 \mathrm{mg} / \mathrm{L} \mathrm{Cl}$.

Although it is conceptually plausible that groundwater from CP Basin could flow into central Frenchman Flat, attempts to develop conservative mixing models involving Water Well \#4 and Water Well 4A were largely unsuccessful, and provided no real insight into whether groundwater is moving from the alluvial aquifer into the LCA in eastern Frenchman Flat. The basic conclusion of this analysis is that the available geochemical data do not strongly support the concept of west-to-east flow in Frenchman Flat.

Bathtub Model

The potential for vertical leakage of groundwater from the alluvium to the LCA can only be addressed at one location within the Frenchman Flat basin - at well ER-5-3 \#2. Although both USGS HTH \#3 and USGS HTH "F" are also completed in the carbonate aquifer in Frenchman Flat (see Figure 7 and Table 5), USGS HTH \#3 does not have saturated 
alluvium or volcanic rocks overlying the LCA (see Lyles et al., 1991), and USGS HTH "F" is lacking stable isotope data.

To conduct the assessment of vertical leakage at ER-5-3 \#2, it was necessary to consider data from nearby LCA wells in southern Yucca Flat as a frame of reference. In particular, it was essential to demonstrate whether a less diluted LCA end-member composition could be identified upgradient of ER-5-3 \#2. If ER-5-3 \#2 was found to be the least diluted LCA groundwater in the region, it would suggest that vertical leakage is less likely.

From a conservative tracer perspective, well ER-3-1, located on the eastern edge of Yucca Flat, appears to meet all of the necessary criteria for a less dilute end-member, including more depleted $\delta \mathrm{D}$ and $\delta^{18} \mathrm{O}$ values, and a higher $\mathrm{Cl}$ concentration relative to ER-5-3 \#2. In addition, the water-level elevation at ER-3-1 (729 $\mathrm{m})$ is above that at ER-5-3 \#2 $(727 \mathrm{~m})$, indicating the potentiometric surface favors southward flow. It should be noted, however, that the hydrogeologic setting of the eastern NTS has not been carefully considered in this analysis. There was more interest in the conceptual possibility that a less dilute groundwater (like ER-3-1) may be flowing into the NTS from the northeast, following the generally accepted (but poorly constrained) "Pahranagat Valley" regional flowpath (Winograd and Friedman, 1972; Thomas et al., 1996; US DOE, 1997).

One potential groundwater-mixing scenario involving ER-3-1 and UE-5 PW-3 is shown on a plot of $\mathrm{Cl}$ versus $\delta \mathrm{D}$ (Figure 18). A mixing line marked with 10 equally spaced increments is included to help visualize the relative proportion of each end-member needed to derive the ER-5-3 \#2 composition. On the basis of this plot, well ER-5-3 \#2 appears to contain a mixture of about 15 percent UE-5 PW-3 and 85 percent ER-3-1. Similar mixing fractions were obtained for all three conservative tracers $\left(\delta \mathrm{D}, \delta^{18} \mathrm{O}\right.$, and $\left.\mathrm{Cl}\right)$ using the two-component mixing equation

$$
\mathrm{C}_{\text {mix }}=\mathrm{C}_{1} X_{1}+\mathrm{C}_{2} X_{2}
$$

where $\mathrm{C}_{\text {mix }}$ is the tracer concentration (or $\delta$-value) of the final mixed water, $\mathrm{C}_{1}$ and $\mathrm{C}_{2}$ are the concentrations (or $\delta$-values) of the two mixing components, and $X_{1}$ and $X_{2}$ are the relative fractions of each component, where $X_{1}+X_{2}=1$. Note that USGS Water Well $\mathrm{C}$ and Water Well C-1 in southern Yucca Flat also plot along this mixing trend, but appear to contain a mixture that is closer to 30 percent UE-5 PW-3 and 70 percent ER-3-1.

While the ER-3-1 plus UE-5 PW-3 mixing model gives a plausible estimate of the relative amount of vertical leakage at well ER-5-3 \#2, this model is not unique. For example, using $\delta \mathrm{D}$ and $\mathrm{Cl}$ data, it is also possible to model the composition of ER-5-3 \#2 (and USGS Water Well C) using a mixture of ER-3-1 and USGS HTH \#3. In this case, ER-5-3 \#2 is predicted to contain approximately 23 percent USGS HTH \#3 and approximately 77 percent ER-3-1, whereas the model for USGS Water Well C predicts a nearly equal mix of both end-members (note the co-linearity of these data points in Figure 18). This model is significant in that it suggests ER-3-1 can be diluted to produce ER-5-3 \#2 without adding groundwater from the overlying alluvial and volcanic units in Frenchman Flat. However, it is important to acknowledge that this model is invalid for $\delta^{18} \mathrm{O}$ because the end-member compositions are isotopically lighter than either ER-5-3 \#2 or USGS Water Well C. There is 
some question regarding the validity of the USGS HTH \#3 $\delta^{18} \mathrm{O}$ value, but the currently accepted value of $-14.2 \%$ could not be verified during this study.

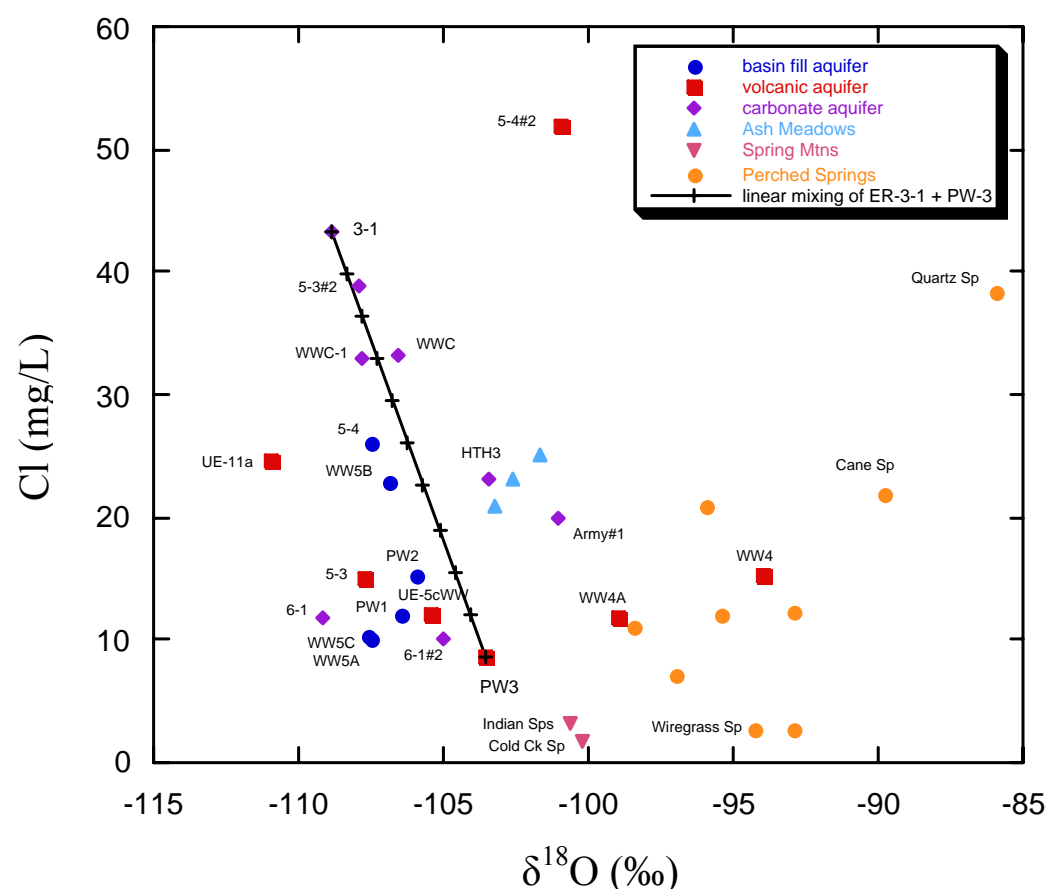

Figure 18. Plot of $\mathrm{Cl}$ versus $\delta \mathrm{D}$ values for groundwater samples from Frenchman Flat and vicinity showing the potential mixing relationship between wells ER-3-1 and UE-5 PW-3. See text for discussion. See page viii for a list of abbreviations of well and spring names.

North-to-south Flow in the LCA

If it is assumed that Frenchman Flat LCA groundwater moves southward toward Army \#1 Water Well (and eventually to Ash Meadows), it is of interest to model the mixing process needed to attain an Army \#1 Water Well composition when starting with ER-5-3 \#2 (or USGS Water Well $\mathrm{C}$ and Water Well C-1). This analysis provides useful insight into the overall fraction of Frenchman Flat LCA water that moves beyond the boundaries of the NTS. Several studies have shown that Ash Meadows and Army \#1 Water Well are likely to contain a significant fraction of groundwater originating from the Spring Mountains (see Thomas et al., 1996; Hershey and Acheampong, 1997). Thus, attention was focused on mixing models that included Frenchman Flat LCA water as well as a Spring Mountains mixing component either Cold Creek Spring or Indian Springs.

Army \#1 Water Well does not lie along a mixing line between ER-5-3 \#2 and Indian Springs or Cold Creek Spring (e.g., Figure 18), and so a third end-member is required to develop the model. Since Army \#1 Water Well is enriched in $\delta \mathrm{D}$ and $\delta^{18} \mathrm{O}$ compared to the Frenchman Flat-Spring Mountains mixing line, the third component must also be enriched in heavy isotopes. Figure 18 shows the compositions of perched springs that are located in the Pintwater and Sheep ranges (east of Frenchman Flat), and the westernmost part of the Spring Mountains (southeast of Frenchman Flat). Also included is Cane Spring, a perched spring 
located on the west side of Mt. Salyer, just west of Frenchman Flat. All of the perched springs in the region are enriched in heavy isotopes relative to Army \#1 Water Well, and hence, there are a number of potential mixing models that can be developed using perched springs as a local recharge end-member.

One possible model (illustrated in Figure 19) is the three-component mixture involving ER-5-3 \#2 + Indian Springs + Cane Spring = Army \#1 Water Well. To determine mixing fractions for this model, it was necessary to solve Equation (1) for two of the components, and then insert the resulting value for $\mathrm{C}_{\text {mix }}$ into a new mixing equation containing the third component. This process is iterative, and the relative fraction of each component is varied until the system of equations converges on a mixing model that is consistent for all three tracers $\left(\delta \mathrm{D}, \delta^{18} \mathrm{O}\right.$, and $\left.\mathrm{Cl}\right)$. A worked example of this process is found in Rose et al. (2002). In many cases, there is no solution that is acceptable for all three tracers (to within \pm 10 percent). For the model shown in Figure 19, the predicted mixing fractions needed to produce an Army \#1 Water Well composition were:

$$
(0.362 \text { - 0.404) ER-5-3 \#2 + (0.433 - 0.483) Indian Springs }+(0.113-0.205) \text { Cane Spring }
$$

The numbers in parentheses show the variation in the mixing fractions of the different tracers. A number of conservative tracer models were successfully developed for Army \#1 Water Well using a Frenchman Flat LCA groundwater (ER-5-3 \#2 or USGS Water Well C) + Spring Mountains carbonate groundwater (Cold Creek Spring or Indian Springs) + various perched springs (or Water Well \#4). Using a more evapoconcentrated perched spring such as Cane or Quartz springs tended to minimize the local recharge contribution to the mixture.

The conservative tracer models for Army \#1 Water Well show a fairly consistent mixing fraction for the Frenchman Flat LCA component (either ER-5-3 \#2 or USGS Water Well C) in the range of 36 to 48 percent. In contrast, the mixing fraction of the Spring Mountains component showed a much wider range that was mostly dependent on the perched spring composition used in the model. The following two models for Army \#1 Water Well illustrate this variability:

$$
(0.358 \text { - 0.360) ER-5-3 \#2 + (0.503 - 0.506) Cold Ck Sp + (0.134 - 0.139) Quartz Sp }
$$

$$
(0.454-0.480) \text { ER-5-3 \#2 + (0.100 - 0.105) Cold Ck Sp + (0.415 - 0.446) Wiregrass Sp }
$$

Models that require a very large fraction of the local recharge component are probably less realistic from a mass-balance perspective since we know the Spring Mountains are a volumetrically significant source of recharge, but the Pintwater Range is not.

Given that the models presently considered involve somewhat lengthy flowpaths within the carbonate aquifer, it is essential to point out that the assumption of $\mathrm{Cl}$ conservatism may not be valid for all parts of this system. Moran and Rose (2003) demonstrated that the geochemical evolution of ${ }^{36} \mathrm{Cl}$ in the LCA is strongly controlled by water-rock interaction with the carbonate host rock. Groundwater that has followed a long flowpath through the LCA tends to evolve toward a low ${ }^{36} \mathrm{Cl} / \mathrm{Cl}$ ratio and a high $\mathrm{Cl}$ concentration. This trend is thought to reflect the leaching of ${ }^{36} \mathrm{Cl}$-absent $\mathrm{Cl}$ from the carbonate rock. Well ER-3-1 is a good example of an LCA groundwater that has undergone extensive water-rock reaction (see Figure 20). 


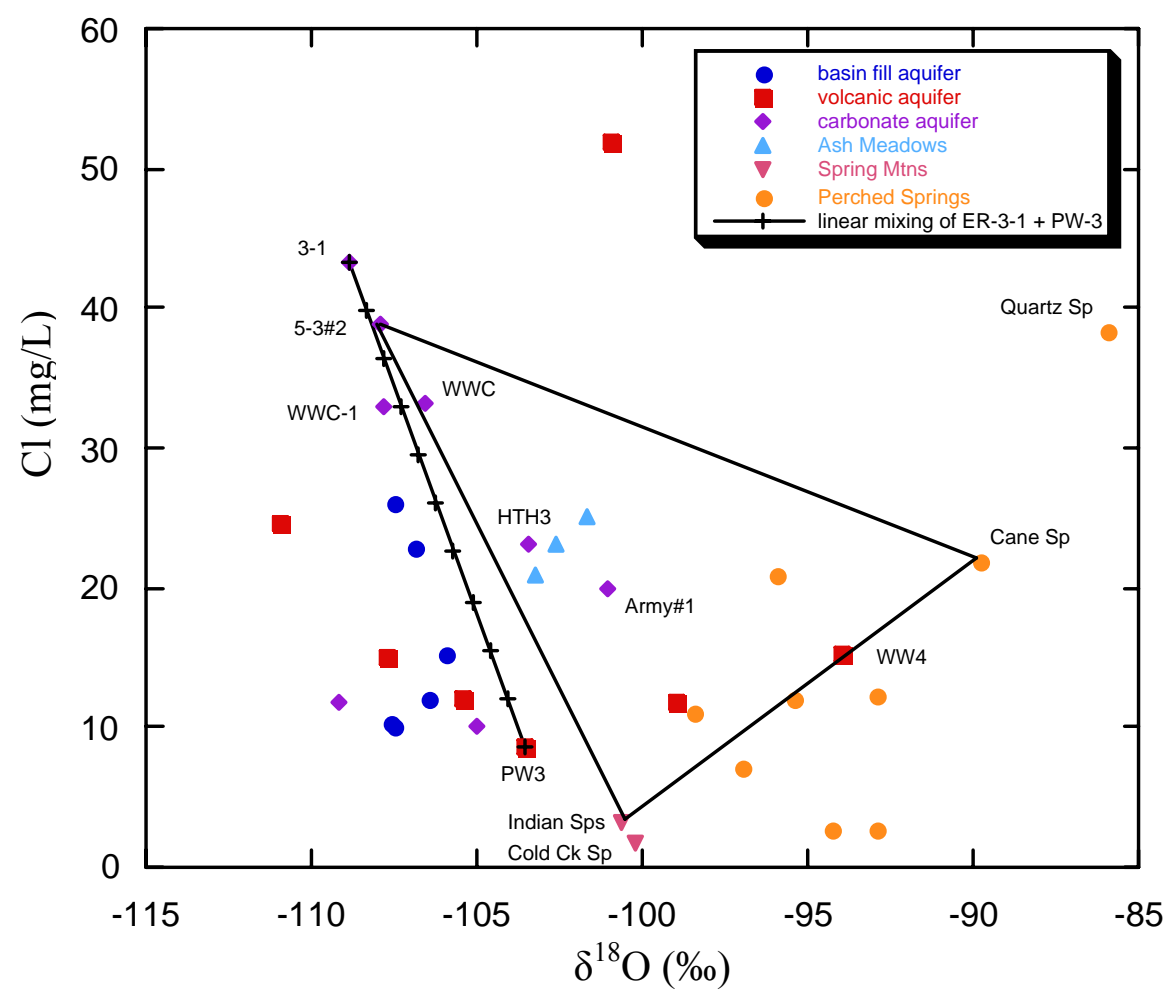

Figure 19. Plot of $\mathrm{Cl}$ versus $\delta \mathrm{D}$ values for groundwater samples from Frenchman Flat and vicinity showing one possible three-component mixing model to explain the observed groundwater composition of Army \#1 Water Well. See page viii for a list of abbreviations of well and spring names.

Cold Creek Spring, which is located close to its source in the Spring Mountains, has a low $\mathrm{Cl}$ concentration $(1.6 \mathrm{mg} / \mathrm{L})$ and a ${ }^{36} \mathrm{Cl} / \mathrm{Cl}$ ratio $\left(5.22 \times 10^{-13}\right)$ very similar to the modern atmospheric value for this region (Fabryka-Martin et al., 1993). Hence, it has undergone very little evolution from water-rock reaction since recharge. Indian Springs, located slightly further downgradient, has a $\mathrm{Cl}$ value of $3.3 \mathrm{mg} / \mathrm{L}$, but a ${ }^{36} \mathrm{Cl} / \mathrm{Cl}$ ratio is lacking for this site. However, it is anticipated that the ${ }^{36} \mathrm{Cl} / \mathrm{Cl}$ ratio would gradually evolve toward lower values along the Spring Mountains pathway to Ash Meadows. These points are of interest because Army \#1 Water Well lies along this same pathway.

In this study, Army \#1 Water Well has been modeled using Spring Mountains end-members that are very dilute in $\mathrm{Cl}$. If $\mathrm{Cl}$ is nonconservative in the LCA, then the actual concentration of $\mathrm{Cl}$ in the Spring Mountains mixing component arriving at Army \#1 Water Well may be much higher than assumed in the models. 

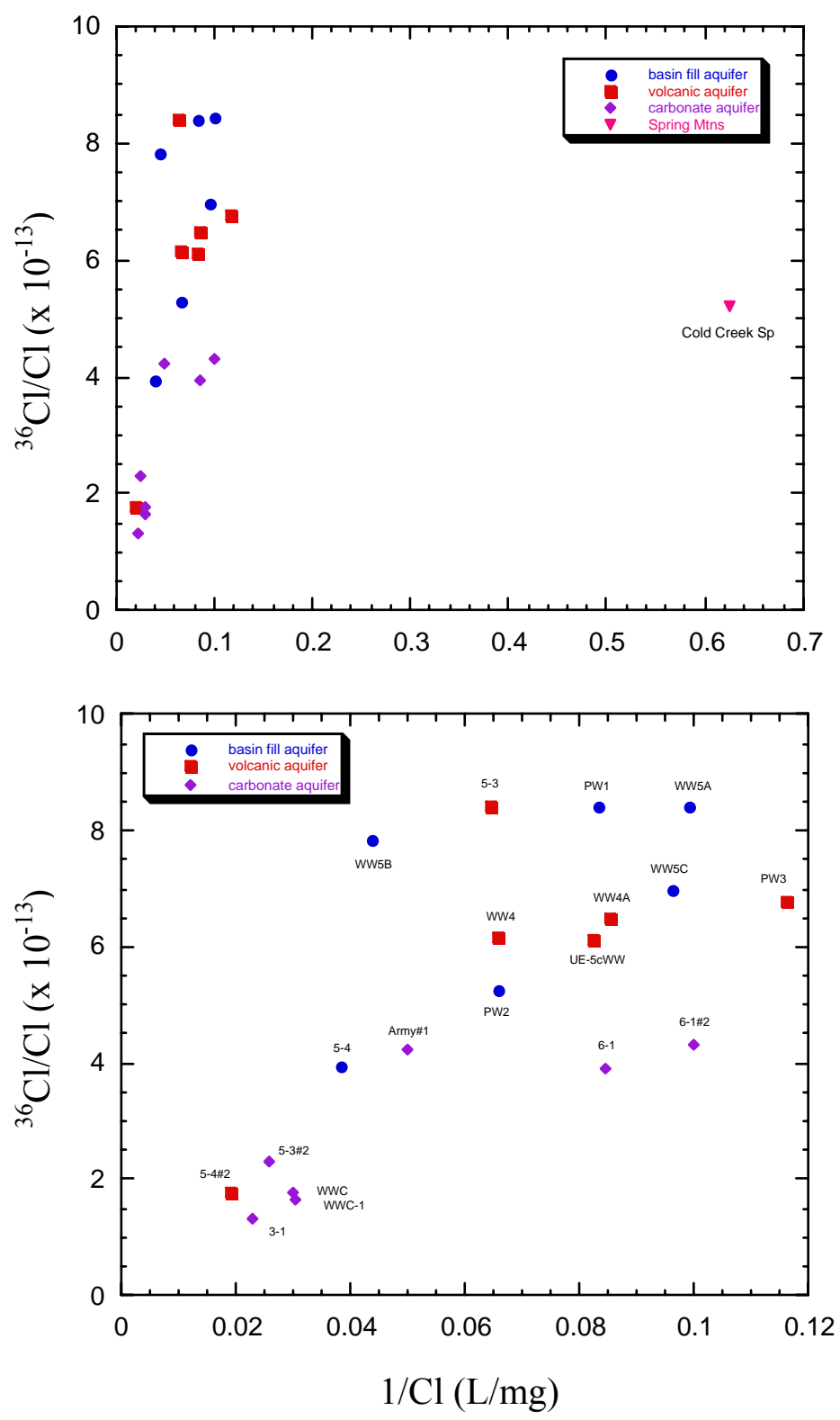

Figure 20. Plot of ${ }^{36} \mathrm{Cl} / \mathrm{Cl}$ versus $1 / \mathrm{Cl}$ for groundwater samples from Frenchman Flat and vicinity. Carbonate groundwater tends to evolve toward lower ${ }^{36} \mathrm{Cl} / \mathrm{Cl}$ ratios and higher $\mathrm{Cl}$ concentrations from water-rock reactions with the carbonate host rock. ${ }^{36} \mathrm{Cl} / \mathrm{Cl}$ data are from Moran and Rose (2003). See page viii for a list of abbreviations of well and spring names.

Of course, it could be argued that Frenchman Flat LCA groundwater may also increase in $\mathrm{Cl}$ on its way to Army \#1 Water Well. However, it is expected that the biggest changes in $\mathrm{Cl}$ concentrations and ${ }^{36} \mathrm{Cl}$ values will occur along the initial part of a flowpath, when the water is furthest from equilibrium with the rock. As a hypothetical example, suppose the same three-component model shown in Figure 18 is used, but now assume that Indian Springs contains $10 \mathrm{mg} / \mathrm{L} \mathrm{Cl}$ instead of $3.3 \mathrm{mg} / \mathrm{L}$. This is equivalent to moving the Indian Springs data point closer to the Army \#1 Water Well data point on Figure 18. The 
three-component model would now predict a 57 to 60 percent contribution from Indian Spring, 28 to 30 percent from ER-5-3 \#2, and 10 to 15 percent Cane Spring. If $\mathrm{Cl}$ is increased to $15 \mathrm{mg} / \mathrm{L}$ in Indian Springs, its mixing fraction increases to 73 percent, and the ER-5-3 \#2 contribution drops to 18 percent.

This hypothetical exercise highlights the uncertainty associated with the mixing models for Army \#1 Water Well given the nonconservative nature of $\mathrm{Cl}$ in the LCA. If it is assumed that the mixing fraction of Spring Mountains water at Army \#1 Water Well is higher than originally predicted, then the volume of LCA groundwater exiting Frenchman Flat will almost certainly be smaller than predicted by the conservative tracer models. It is therefore important to analyze other types of geochemical data together with chemical modeling predictions to determine which of the conservative tracer mixing scenarios are most plausible.

\section{Strontium Tracer Modeling}

Although chemical processes can change the concentration of Sr during groundwater flow, a number of them (mineral precipitation, sorption) do not fractionate isotopic compositions in solution. Furthermore, the ${ }^{87} \mathrm{Sr} /{ }^{86} \mathrm{Sr}$ composition of different aquifers can be very distinct, providing the potential to distinguish different groundwater domains. Therefore, ${ }^{87} \mathrm{Sr} /{ }^{86} \mathrm{Sr}$ ratios have the potential to add insight into processes of flow and transport in regional groundwater studies.

North-to-south Flow

As with the conservative tracers, $\mathrm{Cl}, \delta \mathrm{D}$, and $\delta^{18} \mathrm{O}, \mathrm{Sr}$ and ${ }^{87} \mathrm{Sr} /{ }^{86} \mathrm{Sr}$ do not show consistent patterns of variation in the Frenchman Flat basin. Within the alluvial aquifer, $\mathrm{Sr}$ concentrations are greatest in samples from wells to the north (UE-5 PW-1 and UE-5 PW-2) and least in wells towards the south (Water Well 5A, 5B, 5C), consistent with Cl. However, all alluvial aquifer samples show relatively uniform ${ }^{87} \mathrm{Sr} /{ }^{86} \mathrm{Sr}$ compositions. These $\mathrm{Sr}$ and ${ }^{87} \mathrm{Sr} /{ }^{86} \mathrm{Sr}$ data are consistent either with progressive extraction of $\mathrm{Sr}$ from solution by sorption onto clay particles as water flows from north to south, or with increased dilution of groundwater to the south by a recharge component with a low-Sr concentration and a similar ${ }^{87} \mathrm{Sr} /{ }^{86} \mathrm{Sr}$ value. Difficulties explaining the southward decrease in $\mathrm{Cl}$ concentrations and $\delta \mathrm{D}$ values in these samples have been discussed previously.

Strontium concentrations and ${ }^{87} \mathrm{Sr} /{ }^{86} \mathrm{Sr}$ values for volcanic aquifer samples in Frenchman Flat form a cluster that do not show obvious correlations with their north-to-south spatial distributions (Figure 14). Four of the seven samples have very restricted ${ }^{87} \mathrm{Sr} /{ }^{86} \mathrm{Sr}$ values similar to those in alluvial aquifer samples. Samples USGS Test Well B and ER-5-4 \#2 have very low-Sr concentrations ( 0.015 and $0.0023 \mu \mathrm{g} / \mathrm{g}$, respectively) and are likely affected by sorption of Sr onto zeolitized tuffs, especially in the deep ER-5-4 \#2 sample. Low-Sr concentrations in these waters make modification of ${ }^{87} \mathrm{Sr} /{ }^{86} \mathrm{Sr}$ values much more sensitive to local variations in aquifer rock composition and may explain ${ }^{87} \mathrm{Sr} /{ }^{86} \mathrm{Sr}$ values that deviate from the other volcanic aquifer samples.

Strontium data do not support the possible binary mixing relation suggested by $\delta \mathrm{D}$, $\delta^{18} \mathrm{O}$, and $\mathrm{Cl}$ between ER-5-4 \#2 volcanic aquifer water flowing southward out of Frenchman Flat and Indian Springs LCA water flowing from the east to obtain compositions observed in Army \#1 Water Well. Both waters have substantially lower Sr concentrations and lower ${ }^{87} \mathrm{Sr}{ }^{86} \mathrm{Sr}$ values than Army \#1 Water Well. Substantial addition of Sr by reaction with a mineral component containing high $\mathrm{Sr} / \mathrm{Ca}$ would be required to derive Army \#1 Water Well 
from this mixture of groundwaters. Although this may be possible, other LCA groundwater sources in Frenchman Flat are sufficiently enriched in both $\mathrm{Sr}$ and ${ }^{87} \mathrm{Sr} /{ }^{86} \mathrm{Sr}$ to offer a more plausible explanation.

$\underline{\text { West-to-east Flow }}$

As noted previously in the section on conservative tracers, the west-to-east flowpath introducing groundwater from the Frenchman Flat alluvial or volcanic aquifers into the LCA on the eastern side of the Frenchman Flat basin is difficult to evaluate given the present distribution of samples containing a complete suite of reliable chemical and isotope analyses. However, the likelihood of a flowpath from volcanic aquifer water samples in the CP Basin (Water Well \#4 and Water Well 4A) through northwestern Frenchman Flat (ER-5-3, UE-5 PW-3, UE-5c Water Well, and ER-5-4 \#2) to the LCA in southeastern Frenchman Flat represented by USGS HTH \#3 can be evaluated using available Sr data from these wells.

Volcanic aquifer samples from Water Well \#4, Water Well 4A, and UE-5 PW-3 have nearly identical $\mathrm{Sr}$ concentrations and ${ }^{87} \mathrm{Sr} /{ }^{86} \mathrm{Sr}$ values (Figure 14), indicating that they may have similar sources. Lower $\mathrm{Sr}$ and $\mathrm{Ca}$ concentrations in the other volcanic aquifer wells in Frenchman Flat, along with higher $\mathrm{Cl}$ concentrations and lower $\delta \mathrm{D}$ values, imply that if a genetic correlation between these samples exists, the alkali-earth elements are removed from solution during transport through zeolitized tuffs. The overall similarity of ${ }^{87} \mathrm{Sr} /{ }^{86} \mathrm{Sr}$ compositions in all alluvial and volcanic aquifer groundwater samples in Frenchman Flat makes tracing of specific flowpaths difficult.

However, large differences between Sr characteristics in Frenchman Flat volcanic aquifer and LCA groundwater samples are present and offer more compelling evidence against a connection between volcanic aquifer groundwater to the west with LCA groundwater to the east as represented by USGS HTH \#3. On an Sr-isotope mixing diagram (Figure 21), data from the alluvial and volcanic aquifer groundwater samples plot along a sub horizontal array with variable Sr concentrations and uniform ${ }^{87} \mathrm{Sr} /{ }^{86} \mathrm{Sr}$ values. In contrast, data for LCA groundwater samples from Frenchman Flat define a sub vertical array with uniformly high-Sr concentration (low $1 / \mathrm{Sr}$ values) but variable ${ }^{87} \mathrm{Sr} /{ }^{86} \mathrm{Sr}$ values. Simple binary mixtures of different water samples define straight lines on these mixing plots. USGS HTH \#3 plots at the lower end of the linear array defined by data for other Frenchman Flat LCA samples. Simple binary mixtures of volcanic aquifer water, like UE-5 PW-3 or Water Well \#4, with LCA water sampled at ER-3-1 or ER-5-3 \#2 would result in compositions displaced to the right of the vertical array defined by Frenchman Flat LCA samples. Instead, Sr data show no evidence for mixing of alluvial and volcanic aquifer groundwater with the underlying LCA in the vicinity of Frenchman Flat (with the exception of LCA water sampled at ER-6-1 and ER-6-1 \#2). However, it should be noted that high Sr concentrations in LCA samples and low Sr concentrations in many of the alluvial and volcanic aquifer samples could allow relatively small amounts of mixing (as much as 10 to 20 percent) to go unnoticed in this type of evaluation. Nevertheless, large amounts of a volcanic aquifer or alluvial aquifer component mixed with LCA groundwater are required to derive the much lower ${ }^{87} \mathrm{Sr} /{ }^{86} \mathrm{Sr}$ value observed in USGS HTH \#3. Therefore, Sr data are considered strong evidence against substantial movement of Frenchman Flat volcanic aquifer groundwater to the east into the LCA. 


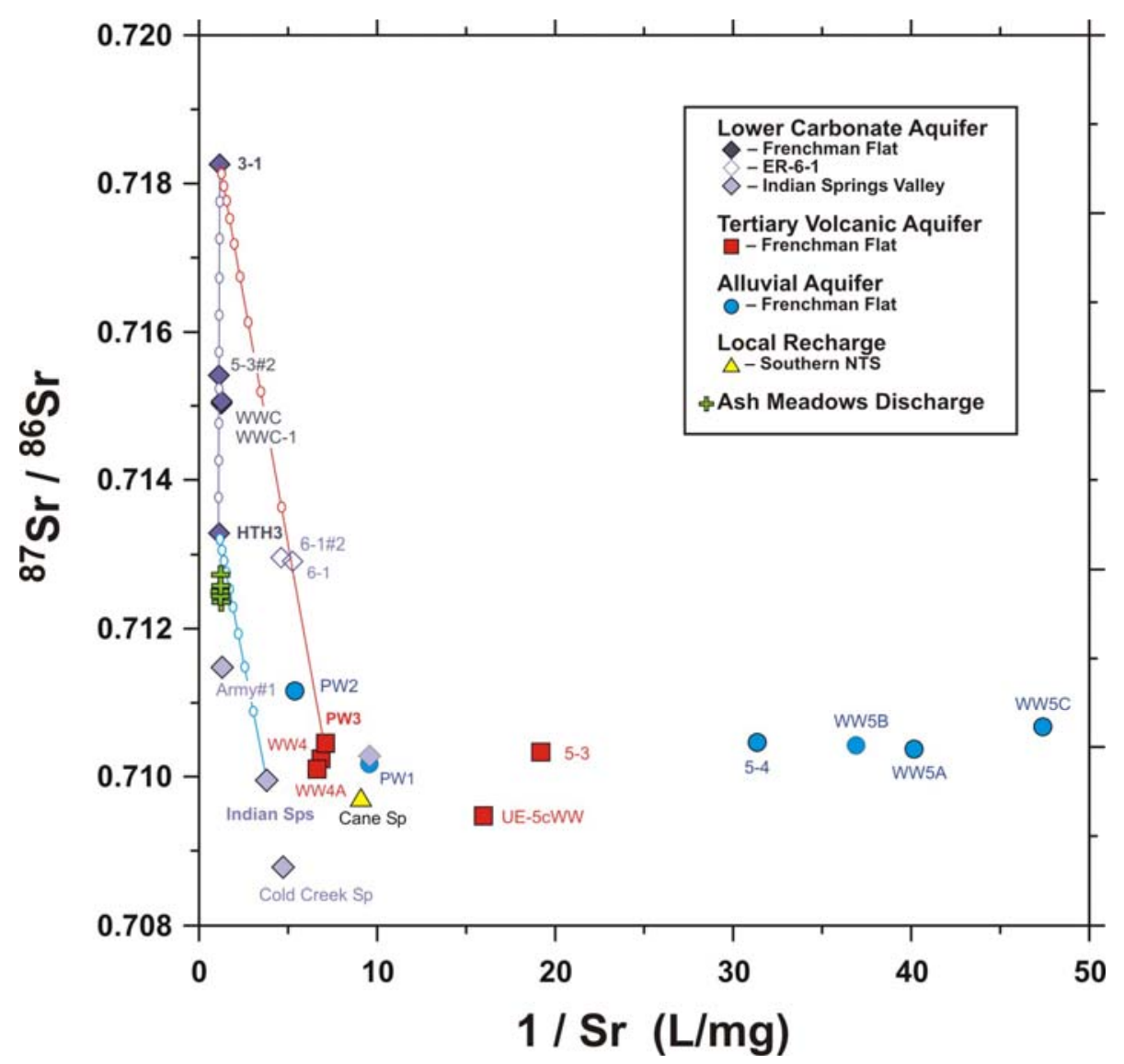

Figure 21. Sr mixing plot $\left({ }^{87} \mathrm{Sr} /{ }^{86} \mathrm{Sr}\right.$ versus $\left.1 / \mathrm{Sr}\right)$ for selected water samples in the Frenchman Flat vicinity. See page viii for a list of abbreviations of well and spring names.

Bathtub Model

The same reasoning using $\mathrm{Sr}$ data to argue against significant west-to-east water movement into the eastern Frenchman Flat LCA can be applied to address vertical movement (downward drainage) within the central Frenchman Flat basin. As shown on Figure 21, the more dilute LCA water found in Yucca Flat (ER-6-1, ER-6-1 \#2) can be derived from a simple binary mixing of lower Sr concentration alluvial and volcanic waters (for example, in Frenchman Flat, UE-5 PW-3, Water Well \#4, or Water Well 4A) with the less dilute LCA water (ER-3-1), assuming, of course, that Yucca Flat volcanic waters have similar $\mathrm{Sr}$ concentrations and ${ }^{87} \mathrm{Sr} /{ }^{86} \mathrm{Sr}$ ratios as seen in Frenchman Flat. This mixture requires large amounts of alluvial and volcanic water (approximately 90 percent) and a small amount of less dilute LCA water (10 percent). This mixture is also consistent with mixing relations between ${ }^{87} \mathrm{Sr} /{ }^{86} \mathrm{Sr}$ and $\mathrm{Cl}$ concentrations (Figure 22). These data indicate that vertical downward flow in Yucca Flat at the ER-6-1 well complex is likely. However, the more dilute LCA water as seen at ER-6-1 and ER-6-1 \#2 in Yucca Flat has not been found in Frenchman Flat except for USGS HTH \#3 on the far eastern edge of the Frenchman Flat basin. 

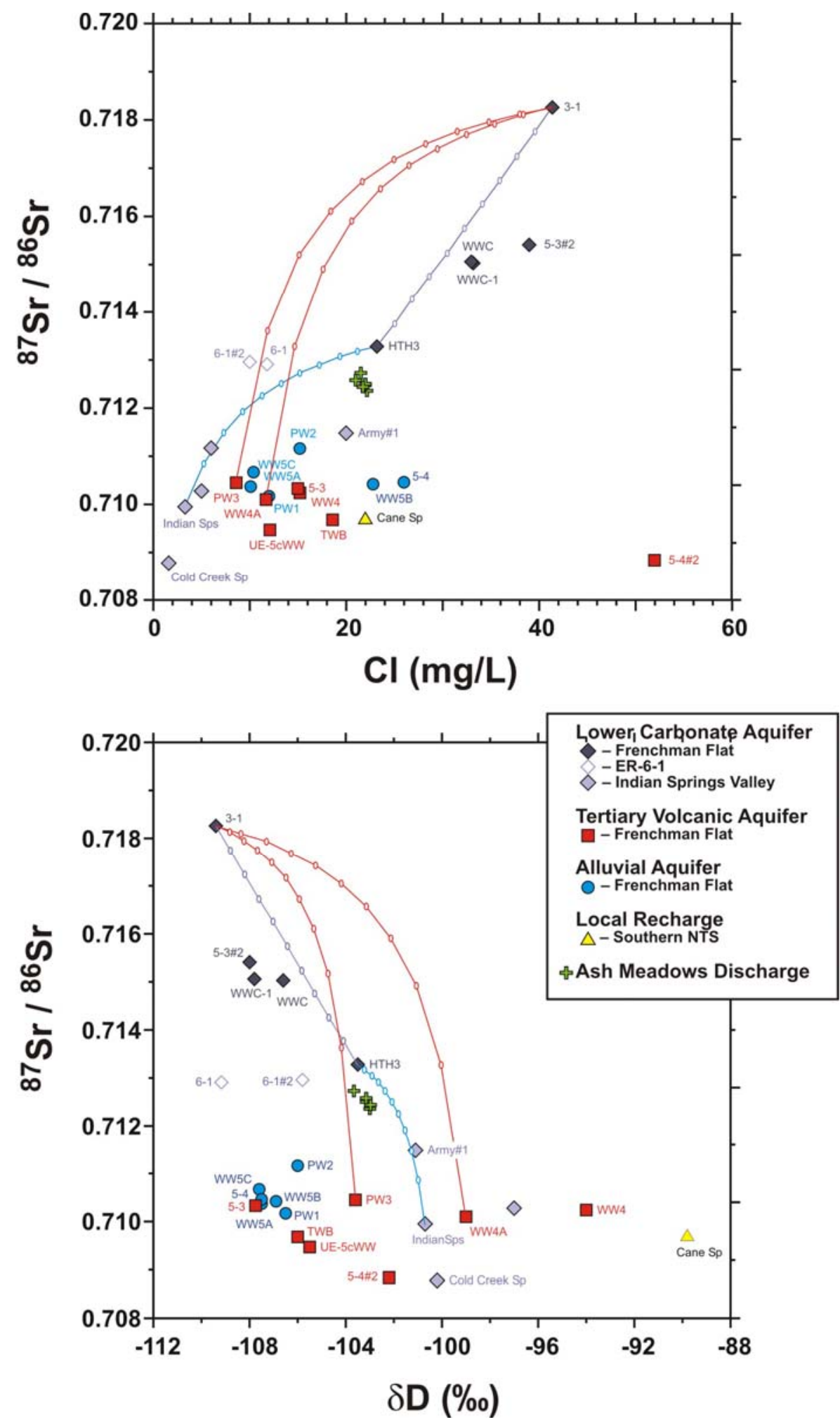

Figure 22. Results of binary mixing of selected end-member compositions on ${ }^{87} \mathrm{Sr} /{ }^{86} \mathrm{Sr}$ versus $\mathrm{Cl}$ and ${ }^{87} \mathrm{Sr} /{ }^{86} \mathrm{Sr}$ versus $\delta \mathrm{D}$. See page viii for a list of abbreviations of well and spring names. 
Derivation of other Frenchman Flat LCA water samples through drainage from the overlying volcanic aquifer is much more problematic based on Sr data. Assuming the less dilute ER-3-1 sample represents an LCA end member, $\mathrm{Sr}$ data require as much as 80 percent of a volcanic aquifer component to yield ${ }^{87} \mathrm{Sr} /{ }^{86} \mathrm{Sr}$ values equivalent to those observed in ER-5-3 \#2 (Figure 21). This amount of volcanic aquifer component should cause a noticeable shift to lower $\mathrm{Sr}$ concentrations in the resulting mixtures, a feature that is not observed. Similar difficulties obtaining ER-5-3 \#2 from ER-3-1 and UE-5 PW-3 through binary mixing are apparent in ${ }^{87} \mathrm{Sr} /{ }^{86} \mathrm{Sr}$ versus $\mathrm{Cl}$ and $\delta \mathrm{D}$ are observed (Figure 22). In both cases, ER-5-3 \#2 has substantially different compositions than those predicted by simple mixing.

Strontium mixing results for ER-5-3 \#2 are significantly different than those calculated from conservative tracers. Mixtures of approximately 15 percent UE-5 PW-3 and 85 percent ER-3-1 derived from conservative tracer data would barely shift the ${ }^{87} \mathrm{Sr} /{ }^{86} \mathrm{Sr}$ composition away from values observed for ER-3-1 (Figures 21 and 22). If the conservative tracer-mixing model is true, some means of radically modifying the ${ }^{87} \mathrm{Sr} /{ }^{86} \mathrm{Sr}$ through water/rock reaction is necessary. Dissolution of marine limestone or dolostone comprising the LCA host rock would likely lower the ${ }^{87} \mathrm{Sr} /{ }^{86} \mathrm{Sr}$ as dissolution proceeded while keeping Sr concentrations elevated. However, this scenario would not account for the increasing $\mathrm{Sr} / \mathrm{Ca}$ ratios observed in Frenchman Flat LCA water (Figure 13) as flow progresses from ER-3-1 southward to other LCA wells or for the observed decrease in dissolved $\mathrm{Ca}$ in wells to the south (although dissolved bicarbonate increases from ER-3-1 to ER-5-3 \#2 and USGS Water Well C and Water Well C-1). In addition, alluvial and volcanic aquifer water is already near saturation with respect to calcite and does not cause a dramatic undersaturation once mixed into the LCA. Therefore, observed Sr data suggest that vertical drainage from the volcanic aquifer is an unlikely process in Frenchman Flat and that some other means of deriving intermediate Frenchman Flat LCA water samples is needed.

Models based on conservative tracers also permit the derivation of ER-5-3 \#2 and USGS Water Well C samples by mixing of ER-3-1 and USGS HTH \#3 end members. These scenarios are broadly consistent with $\mathrm{Sr}$ data and allow maintenance of high dissolved-Sr concentrations without large amounts of water/rock interaction. Results of binary mixing using ${ }^{87} \mathrm{Sr} /{ }^{86} \mathrm{Sr}$ data imply that ER-5-3 \#2 and the USGS Water Well $\mathrm{C}$ samples may be derived from approximately 40 percent ER-3-1 and 60 percent USGS HTH \#3 (Figures 21 and 22), although Sr-Ca mixing results indicate larger proportions of ER-3-1 (Figure 13). These data may reflect south-southwestward flow through the LCA beneath Frenchman Flat that consists of a series of sub parallel flowpaths with water containing higher ${ }^{87} \mathrm{Sr} /{ }^{86} \mathrm{Sr}$, greater solute contents, and lighter $\delta \mathrm{D}$ and $\delta^{18} \mathrm{O}$ towards the northwest and water with lower ${ }^{87} \mathrm{Sr} /{ }^{86} \mathrm{Sr}$, lesser solute contents, and heavier stable isotopes towards the southeast. Although some lateral dispersion may be present in samples across this zone, the dominant southsouthwesterly flow pattern reflects the overall structural grain of Basin-and-Range faulting in the immediate vicinity.

\section{North-to-south Flow in the LCA}

Groundwater in the LCA that flows south to southwesterly out of the vicinity of Frenchman Flat is likely to contribute to groundwater present at Army \#1 Water Well and the Ash Meadows discharge area. Both Army \#1 Water Well and Ash Meadows groundwater have elevated $\mathrm{Sr}$ concentrations that are more similar to values observed in the Frenchman Flat LCA samples. Strontium, $\mathrm{Ca}, \mathrm{Cl}$, and $\delta \mathrm{D}$ compositions from Army \#1 Water Well 
commonly plot between values for samples from USGS HTH \#3 and Indian Springs (Figures 13 and 23). Although simple binary mixing relations imply that Army \#1 Water Well consists of as much as 80 percent USGS HTH \#3 and that Ash Meadows discharge may consist of up to 90 percent USGS HTH \#3, simple mixing models are inappropriate, as Sr data for Army \#1 Water Well do not fall on the Sr mixing line between data from USGS HTH \#3 and Indian Springs (Figure 21).

Compositional fields for three-component mixtures between Frenchman Flat LCA, Indian Springs, and a local recharge described in the section on conservative tracers typically include Army \#1 Water Well. However, mixing proportions commonly are not consistent between different constituents. Relations between $\mathrm{Sr}$ and $\mathrm{Cl}, \delta \mathrm{D}$, as well as $\mathrm{Ca}$ imply that USGS HTH \#3 may be a more reasonable Frenchman Flat LCA end member than ER-5-3 \#2 (Figures 13 and 23). Compared to mixing based on Sr concentration alone, use of ${ }^{87} \mathrm{Sr} /{ }^{86} \mathrm{Sr}$ data from USGS HTH \#3, Indian Springs, and Cane Spring end members dramatically decreases the proportion of USGS HTH \#3 required to make Army \#1 Water Well to only about 10 to 20 percent (Figure 24). However, mixing proportions of either Indian Springs or Cane Spring varies dramatically from 0 to 100 percent.

The discrepancy of mixing results observed in Figure 24 indicates that $\mathrm{Sr}$ (and perhaps $\mathrm{Cl}$ as well) is probably not conservative and requires consideration of advection-reaction models as well as mixing. These models have not been developed, largely because of the absence of information on the isotopic composition of $\mathrm{Sr}$ in the various aquifer rocks. The ${ }^{87} \mathrm{Sr} /{ }^{86} \mathrm{Sr}$ composition of Paleozoic carbonate rocks can vary substantially in the NTS region depending on the presence or absence of mineralization by fluids containing elevated ${ }^{87} \mathrm{Sr} /{ }^{86} \mathrm{Sr}$ (Peterman et al., 1994). Advection-reaction models (Johnson and Depaolo, 1994; Johnson et al., 2000; Marshall and Futa, 2001) that utilize both rock and water compositions may give additional constraints on the evolution of groundwater into and out of the Frenchman Flat study area.

Summary

Strontium data analyzed in alluvial aquifer, volcanic aquifer and LCA groundwater samples are useful for characterizing different flow systems in Frenchman Flat. Existing data for alluvial and volcanic samples in Frenchman Flat show a range in $\mathrm{Sr}$ concentrations, but only minor variation in ${ }^{87} \mathrm{Sr} /{ }^{86} \mathrm{Sr}$ values. Although these data are consistent with greater extraction of Sr by sorption onto zeolitized tuffs in the more southerly samples, there is no compelling evidence to support north-to-south flowpaths within the shallower aquifers. Strontium data do not support a possible genetic link between volcanic aquifer water from deep zones in well ER-5-4 \#2 and water sampled from Army \#1 Water Well that is permissible using conservative tracer mixing models alone.

In addition, $\mathrm{Sr}$ isotope data do not support a model of west-to-east flow from the alluvial and volcanic aquifer units in the CP or western Frenchman Flat basins to LCA on the east side of Frenchman Flat. Mixing of water from the shallower aquifers with LCA groundwater present in northern Frenchman Flat does not produce ${ }^{87} \mathrm{Sr} /{ }^{86} \mathrm{Sr}$ compositions similar to those observed in the LCA from USGS HTH \#3. Patterns of variation in $\mathrm{Sr}$ concentrations and ${ }^{87} \mathrm{Sr} /{ }^{86} \mathrm{Sr}$ compositions are distinct for volcanic aquifer and alluvial aquifer groundwater compared to values observed in the LCA beneath Frenchman Flat. These data can be used to demonstrate that little or no leakage occurs between the shallower alluvial and volcanic aquifer into the deeper LCA. One exception to this rule is observed in LCA water 
from well ER-6-1 and ER-6-1 \#2 in eastern Yucca Flat, which has Sr characteristics implying that the sample may consist of about 90 percent volcanic aquifer.
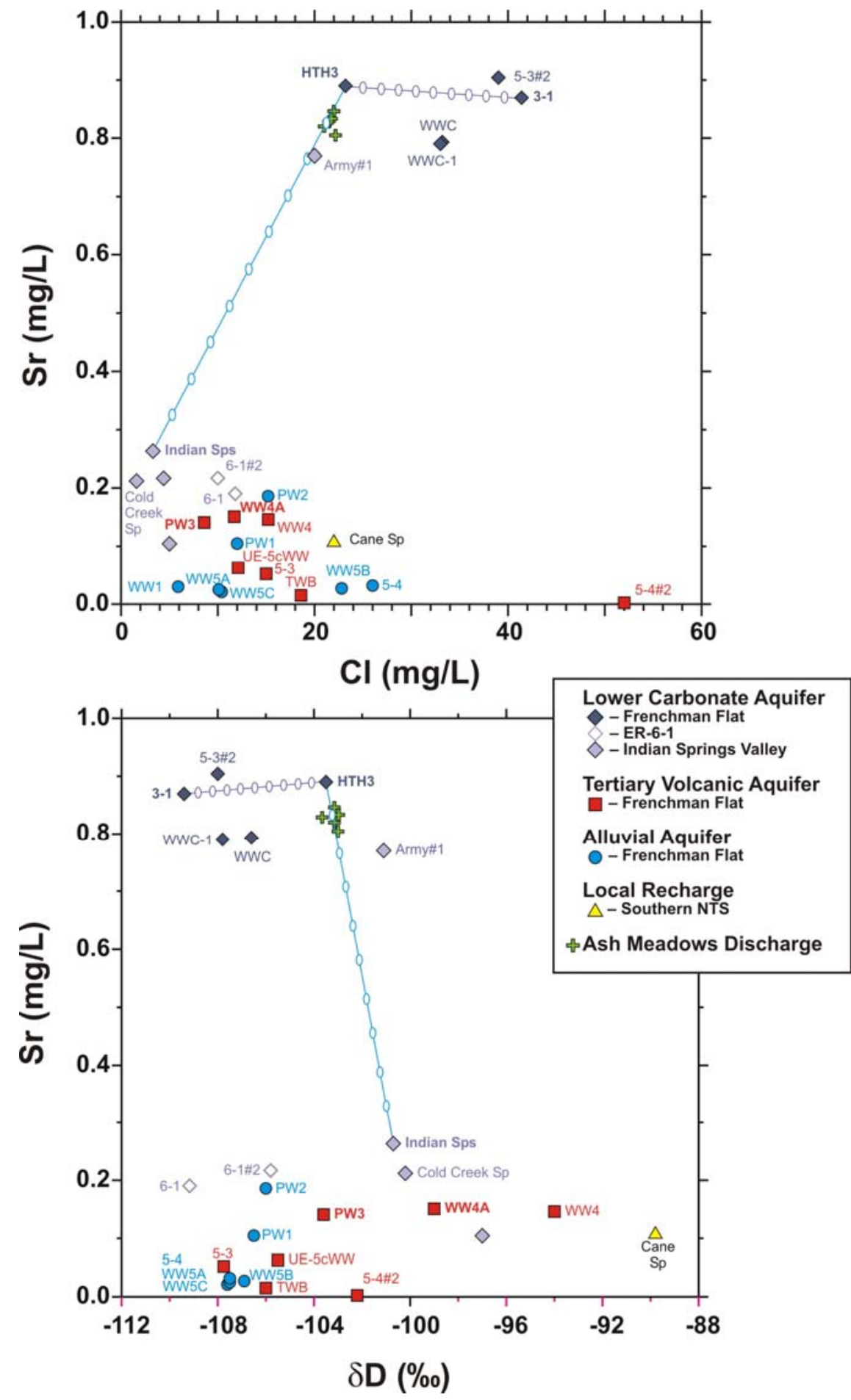

Figure 23. Concentration of $\mathrm{Sr}$ versus $\mathrm{Cl}$ and $\mathrm{Sr}$ versus $\delta \mathrm{D}$ for selected samples from the Frenchman Flat vicinity. See page viii for a list of abbreviations of well and spring names. 

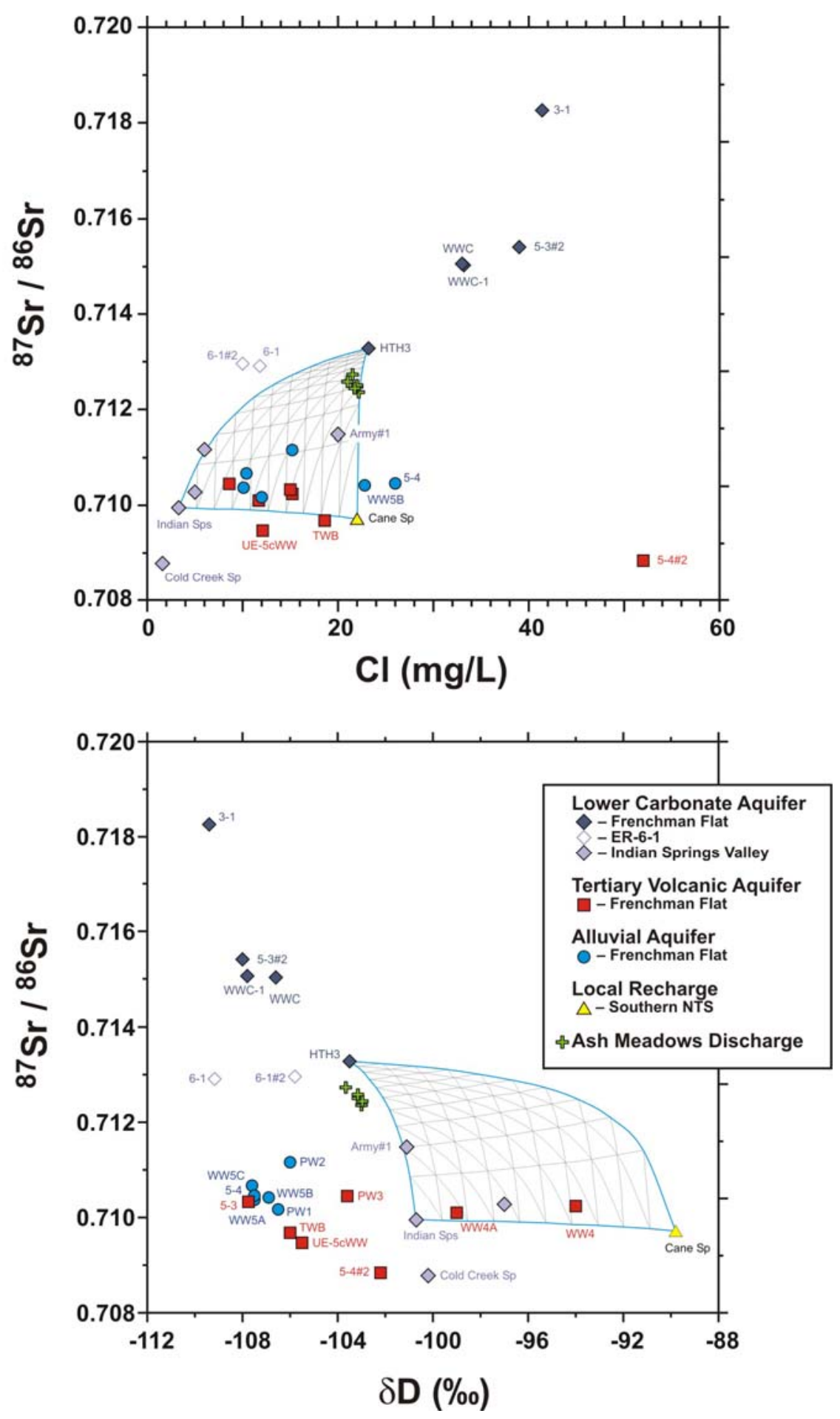

Figure 24. Three-component mixing models for USGS HTH \#3, Indian Springs, and Cane Spring end members. See page viii for a list of abbreviations of well and spring names.

Strontium data in LCA groundwater within Frenchman Flat is most consistent with flow to the south-southwest along the structural grain in the region that is largely isolated from the overlying aquifers. Compositions of LCA in northwestern Frenchman Flat and 
southernmost Yucca Flat are intermediate between a least dilute, most radiogenic (high ${ }^{87} \mathrm{Sr} /{ }^{86} \mathrm{Sr}$ ) LCA end member to the north (ER-3-1) and a more dilute, less radiogenic LCA end member to the southeast (USGS HTH \#3). Mixtures of this component with east-to-west flow from Indian Springs are likely to yield groundwater with compositions observed at Army \#1 Water Well. However, Sr data do not give consistent mixing proportions with conservative tracers and likely require more complex mixing end members that have yet to be sampled, or advection-reaction processes. Isotope data for reservoir rocks are not available for modeling this more complex process.

\section{Water-rock Reaction Models and Travel-time Estimates}

The conceptual groundwater sources, mixing, and flow directions in the Frenchman Flat area identified using hydrogeologic information and groundwater flow models, and that were evaluated using conservative water chemistry mixing models, are further evaluated by geochemical modeling using all major-ion chemistry and accounting for geochemical reactions. Geochemical models are used to evaluate whether groundwater sources, flowpaths, and mixing proportions of different groundwaters determined from conservative tracers $(\delta \mathrm{D}$, $\delta^{18} \mathrm{O}$, and $\mathrm{Cl}$ ) are consistent with the major-ion chemistry and geochemical processes within the flow system. Conservative water-chemistry tracers were used first to delineate probable flowpaths and mixing processes. These flowpaths were then modeled using the computer codes NETPATH (Plummer et al., 1994) and PHREEQC (Parkhurst and Appelo, 1999). NETPATH performs speciation calculations to determine mineral saturation states, net mass transfer of major ions during chemical reactions along a proposed flowpath, and carbon isotope fractionations for carbon entering and exiting the groundwater. By modeling the isotopic evolution of dissolved inorganic carbon (DIC) along a flowpath, it is also possible to calculate groundwater travel times. PHREEQC performs the same calculations as NETPATH, except that PHREEQC does not perform the carbon isotope calculations, however, PHREEQC allows for variability (percent error) to be specified for the calculations. The percent error allowed for the mixing and geochemical processes can be set for the entire solution and for individual parameters within the solution. Viable water-rock geochemical models developed using measured water chemistry and minerals identified in the aquifer provide independent validation of proposed flowpaths and mixing processes. Water analyses used in the geochemical models are the most recent available with complete chemical and isotopic data and with analytical balance of less than five percent.

Mineral dissolution and precipitation reactions used in the NETPATH and PHREEQC models are constrained by thermodynamic calculations. These calculations determine the saturation state of minerals in the water. Minerals that have been identified in the aquifer and are undersaturated can only dissolve, whereas those that are supersaturated can only precipitate from the water or form by incongruent dissolution. Additionally, NETPATH calculates the $\delta^{13} \mathrm{C}$ composition of the water at the end of the flowpath model (final water) using all carbon-containing phases involved in the geochemical reactions and the associated

$\delta^{13} \mathrm{C}$ fractionations of those reactions. Travel-time calculations using NETPATH require that DIC isotopic data are available for water samples along the flowpath and the minerals and gases interacting with the groundwater. The $\delta^{13} \mathrm{C}$ values calculated by the geochemical model must match the $\delta^{13} \mathrm{C}$ values measured in the final water for the model to be valid. Carbon isotopes of dissolved organic carbon (DOC) are used as an independent estimate of groundwater age that can be compared to the travel times calculated using DIC data. The 
geochemical models are limited by (1) knowledge of the minerals and gases that are present in the aquifer and their chemical and isotopic compositions, and (2) available groundwater chemistry data along potential flowpaths. The geochemical model solutions are non-unique so more than one model can describe the changes in water chemistry along a particular flowpath.

\section{Geochemical Modeling Approach}

Geochemical modeling in this report used historical water chemistry and isotopic data from the Frenchman Flat area (Appendix A) incorporating mineralogical data for volcanic HSUs from Rose et al. (2002) and carbonate HSUs from Winograd and Thordarson (1975) and Thomas et al. (1996). Mineral and glass compositions used in the models were from Rose et al. (2002) and Thomas et al. (2002); $\delta^{13} \mathrm{C}$ data for calcite are shown in Table 6. The reactive or exchangeable phases used in the geochemical models included calcite, dolomite, composite volcanic glass, composite feldspar, composite clay, composite biotite, $\mathrm{SiO}_{2}$, pyrite, gypsum, halite, and $\mathrm{Ca} / \mathrm{Mg}-\mathrm{Na}$ ion exchange. Although zeolite minerals are present in alluvial and volcanic HSUs, they were not included as a phase in geochemical modeling of Frenchman Flat since previous geochemical modeling for the Pahute Mesa CAU produced similar results when including either a composite clay or a composite zeolite (Rose et al., 2002; Thomas et al., 2002). The chemical compositions of the composite volcanic glass, feldspar, clay, and biotite represent average compositions for these phases as measured for the Timber Mountain and Paintbrush hydrostratigraphic units in the Pahute Mesa CAU (Thomas et al., 2002, Table 1-3). These volcanic hydrostratigraphic units have been identified in northern and central Frenchman Flat. For a geochemical model to be considered valid, mass transfers were limited to less than 5.0 millimoles of a given mineral per liter of water. Mass transfers greater than 5 millimoles per liter were assumed to indicate unrealistically large amounts of material moving into or out of solution. A detailed description of the construction and limitations of the geochemical models is found in Thomas et al. (2002).

A summary of successful NETPATH geochemical models for the proposed groundwater sources, mixing, and flowpaths is presented in Table 7. Complete modeling results are included in Appendix B. A geochemical model is valid when the calculated concentrations of the conservative tracers, $\delta \mathrm{D}$ and $\mathrm{Cl}$, for the final water are in agreement with actual measured concentrations (Table 7). Note that $\delta^{18} \mathrm{O}$ was not used as a conservative tracer since it is directly related to $\delta \mathrm{D}$ and would produce very similar results. NETPATH and PHREEQC calculate the mixture of the different initial waters on the basis of the major-ion chemistry of the initial and final waters and the geochemical reactions along the flowpath. This approach differs from that of mixing based solely on the conservative tracers where water-rock reactions are ignored. Geochemical model calculations were performed initially excluding $\delta \mathrm{D}$. These models calculated mixing ratios based upon geochemical reactions; mixing ratios were then used to manually calculate the $\delta \mathrm{D}$ and $\mathrm{Cl}$ concentration of the final water. Models including $\delta \mathrm{D}$ calculated the mixing ratios based upon $\delta \mathrm{D}$ and then calculated the mass transfers based on the mixing ratios. The results of the mass transfers were then evaluated for their validity geochemically. 
Table 6. Carbon-13 data for alluvium, vein calcite in volcanic rocks, and carbonate rock.

\begin{tabular}{|c|c|c|c|}
\hline Sample & Description & $\begin{array}{l}\delta^{13} \mathrm{C} \\
(\%)\end{array}$ & \\
\hline \multicolumn{4}{|c|}{ Yucca Flat Tuff Confining Unit (vein calcite in saturated zeolitized volcanic rocks, Yucca Flat) } \\
\hline UE-7az (337.0 m bgs) & $\begin{array}{l}\text { 3-mm open cavity; } 1 \text { - to 2-mm free-standing calcite } \\
\text { xls }\end{array}$ & -5.30 & \\
\hline UE-7az (617.8 m bgs) & 1- to 2-mm-wide joint; calcite + quartz filling & 0.44 & \\
\hline UE-7az (648.9 m bgs) & 1-mm-wide joint with calcite filling & -1.46 & \\
\hline UE-7az (650.4 m bgs) & 10-mm-wide calcite vein; cleavable masses & 0.19 & \\
\hline UE-7ba (678.1 m bgs) & 3-mm-wide joint, quartz + minor calcite filling & -4.37 & \\
\hline UE-7ba (683.4 m bgs) & 3-mm-wide joint, quartz + calcite filling & -2.04 & \\
\hline UE-7ba (690.5 m bgs) & 2- to 4-mm-wide joint, filled with calcite & -2.70 & \\
\hline UE-7ba (692.4 m bgs) & 4- to 9-mm-wide joint, massive brown calcite filling & -1.97 & \\
\hline UE-7ba (719.5 m bgs) & 3-mm-wide joint filled $\mathrm{w} /$ smectite; $\sim 1$ percent calcite & -4.20 & \\
\hline UE-7ba (722.5 m bgs) & $\begin{array}{l}\text { 3-mm-wide joint filled w/ illite }+ \text { smectite; minor } \\
\text { calcite }\end{array}$ & -3.02 & \\
\hline UE-7bc (776.2 m bgs) & $\begin{array}{l}\text { 10-mm-wide fracture w/ calcite, quartz, K-spar, } \\
\text { zeolites }\end{array}$ & -3.64 & \\
\hline UE-7bc (789.6 m bgs) & 3- to 10 -mm-wide massive calcite vein & -4.29 & \\
\hline UE-7f (384.2 $\mathrm{m}$ bgs $)$ & $\begin{array}{l}\text { 2- to 3-mm partially open vein } \mathrm{w} / \text { euhedral calcite xls } \\
(<1 \mathrm{~mm})\end{array}$ & -0.63 & \\
\hline UE-7f (423.2 m bgs) & 10-mm partially open vein; blocky calcite xls to $3 \mathrm{~mm}$ & -7.30 & \\
\hline UE-7f (754.6 m bgs) & $\begin{array}{l}\text { 3-mm open joint w/ euhedral, bladed calcite, analcime, } \\
\text { Mn-ox }\end{array}$ & -0.34 & \\
\hline UE-7f (756.7 m bgs) & $\begin{array}{l}\text { 1- to } 2 \text {-mm calcite replacement vein in Fe-oxide- } \\
\text { stained tuff }\end{array}$ & -0.97 & \\
\hline Average & & -2.86 & \\
\hline \multicolumn{4}{|c|}{ U-1a tunnel complex (unsaturated alluvium, Yucca Flat, $\sim 300 \mathrm{~m}$ bgs) } \\
\hline & & $\begin{array}{l}\text { with } \\
\text { clasts }\end{array}$ & $\begin{array}{r}\text { without } \\
\text { clasts }\end{array}$ \\
\hline U-1a.102C (0+77) sample V1 & fine-grained calcite in alluvial matrix & -1.08 & -1.08 \\
\hline U-1a.102C (0+77) sample V1 & carbonate clast & -4.48 & \\
\hline U-1a.102C (0+77) sample V1 & calcite spar - rind on clast & -3.60 & -3.60 \\
\hline U-1a.102C (0+77) sample V2 & fine-grained calcite in alluvial matrix & -3.16 & -3.16 \\
\hline U-1a.102C (0+77) sample V3 & fine-grained calcite in alluvial matrix & -1.31 & -1.31 \\
\hline U-1a.102C $(0+77)$ sample V4 & fine-grained calcite in alluvial matrix & 0.43 & 0.43 \\
\hline U-1a.102C (0+77) sample V5 & fine-grained calcite in alluvial matrix & -2.49 & -2.49 \\
\hline U-1a.102C (0+77) sample V5 & carbonate clast (dolomite) & -0.67 & \\
\hline U-1a.102C $(0+77)$ sample V5 & caliche - rind on clast & -2.99 & -2.99 \\
\hline U-1a.102C (0+77) sample H1 & fine-grained calcite in alluvial matrix & -1.24 & -1.24 \\
\hline U-1a.102C (0+77) sample H2 & fine-grained calcite in alluvial matrix & -2.87 & -2.87 \\
\hline U-1a.102C $(0+77)$ sample H3 & fine-grained calcite in alluvial matrix & -1.03 & -1.03 \\
\hline U-1a.102C (0+77) sample H4 & bulk sample (milled) & 2.32 & \\
\hline U-1a.102C (0+77) sample H4 & carbonate clast & 3.14 & \\
\hline
\end{tabular}


Table 6. Carbon-13 data for alluvium, vein calcite in volcanic rocks, and carbonate rock (continued).

\begin{tabular}{|c|c|c|c|c|c|}
\hline Sample & \multicolumn{2}{|c|}{ Description } & \multicolumn{2}{|c|}{$\begin{array}{l}\delta^{13} \mathrm{C} \\
(\%)\end{array}$} & \\
\hline U-1a.102C (0+77) sample H4 & \multicolumn{2}{|c|}{ caliche - rind on clast } & -3.42 & & -3.42 \\
\hline U-1a.102C $(0+77)$ sample H5 & \multicolumn{2}{|c|}{ fine-grained calcite in alluvial matrix } & -1.28 & & -1.28 \\
\hline U-1a.102D (0+21) sample D1 & \multicolumn{2}{|c|}{ fine-grained calcite in alluvial matrix } & -2.62 & & -2.62 \\
\hline U-1a.102D $(0+21)$ sample D2 & \multicolumn{2}{|c|}{ air-fall tuff layer } & -5.25 & & -5.25 \\
\hline U-1a.01 main drift $(4+60)$ & \multicolumn{2}{|c|}{ calcite spar - rind on clast } & -3.43 & & -3.43 \\
\hline U-1a.01 main drift $(6+00)$ & \multicolumn{2}{|c|}{ caliche stringer in matrix } & -4.59 & & -4.59 \\
\hline U-1a.01 main drift $(7+50)$ & \multicolumn{2}{|c|}{ air-fall tuff } & -5.59 & & -5.59 \\
\hline U-1a.02 $(2+50)$ & \multicolumn{2}{|c|}{ caliche stringer in matrix } & -3.60 & & -3.60 \\
\hline $\mathrm{U}-1 \mathrm{a} .02(2+60)$ & \multicolumn{2}{|l|}{ fault gouge } & -5.12 & & -5.12 \\
\hline U-1a.03 x-cut D $(0+39)$ & \multicolumn{2}{|c|}{ calcite spar in vug } & -5.53 & & -5.53 \\
\hline U-1a.03 x-cut D (0+39) & \multicolumn{2}{|c|}{ matrix (adjacent to vug) } & -4.41 & & -4.41 \\
\hline U-1a.03 x-cut B (0+32) & \multicolumn{2}{|c|}{ carbonate clast (dolomite) } & 1.43 & & \\
\hline U-1a.03 x-cut B $(0+32)$ & \multicolumn{2}{|c|}{ calcite spar - rind on clast } & \multicolumn{2}{|l|}{-4.16} & -4.16 \\
\hline \multicolumn{3}{|l|}{ Average } & \multicolumn{2}{|l|}{-2.47} & -3.11 \\
\hline \multicolumn{3}{|c|}{ Carbonate bedrock samples from NTS boreholes/wells } & $\begin{array}{l}\delta^{13} \mathrm{C} \\
(\%)\end{array}$ & calcite & dolomite \\
\hline \multicolumn{2}{|c|}{ Army \#1 Water Well (345.6 m bgs) } & limestone whole rock & 4.26 & 4.26 & \\
\hline \multicolumn{2}{|c|}{ Army \#1 Water Well (345.6 m bgs) } & calcite fracture lining & 2.57 & 2.57 & \\
\hline \multicolumn{2}{|c|}{ UE-1a $(157.0 \mathrm{~m}$ bgs $)$} & limestone whole rock & -1.79 & -1.79 & \\
\hline \multicolumn{2}{|c|}{ USGS Water Well C (472.4-to-474.0 m bgs) } & limestone whole rock & -0.65 & -0.65 & \\
\hline \multicolumn{2}{|c|}{ Water Well C-1 (481.6-to-484.6 m bgs) } & limestone whole rock & -0.42 & -0.42 & \\
\hline \multicolumn{2}{|l|}{ ER-3-1 (786.4 m bgs) } & calcite vein & -0.66 & -0.66 & \\
\hline \multicolumn{2}{|l|}{ ER-3-1 (792.5 m bgs) } & calcite vein & -0.56 & -0.56 & \\
\hline \multicolumn{2}{|l|}{ ER-6-1 (804.7 m bgs) } & dolomite whole rock & 0.70 & & 0.70 \\
\hline \multicolumn{2}{|l|}{ ER-6-1 (855.9 m bgs) } & dolomite whole rock & 0.80 & & 0.80 \\
\hline \multicolumn{2}{|l|}{ ER-6-1 (955.9 m bgs) } & calcite spar on fracture surface & -1.34 & -1.34 & \\
\hline ER-6-1 (956.3 m bgs) & & $\begin{array}{l}\text { calcite spar on fracture surface } \\
\text { lower carbonate aquifer - }\end{array}$ & -2.57 & -2.57 & \\
\hline UE-7f ( $860.2 \mathrm{~m}$ bgs $)$ & & $\begin{array}{l}\text { bedrock } \\
\text { 2-mm calcite vein in carbonate }\end{array}$ & -1.14 & -1.14 & \\
\hline UE-7f (860.2 m bgs) & & bedrock & -2.66 & -2.66 & \\
\hline UE-10j (643.1m bgs) & & dolomite whole rock & 0.34 & & 0.34 \\
\hline UE-10j (694.9 m bgs) & & dolomite whole rock & 0.43 & & 0.43 \\
\hline UE-15d (1828.2 m bgs) & & dolomite whole rock & -1.18 & & -1.18 \\
\hline UE-15i (80.2 m bgs) & & limestone whole rock & -0.04 & -0.04 & \\
\hline UE-16d (303.6 mbgs) & & limestone whole rock & 5.57 & 5.57 & \\
\hline Average & & & 0.35 & 0.41 & 0.22 \\
\hline
\end{tabular}


Table 7. Summary of conservative mixing and geochemical models.

\begin{tabular}{|c|c|c|c|c|c|c|c|c|c|c|c|}
\hline North-to-sout & low & & & $\begin{array}{c}\delta^{13} \mathrm{C} \\
\text { measured }\end{array}$ & $\begin{array}{c}\delta^{13} \mathrm{C} \\
\text { calculated }\end{array}$ & $\begin{array}{c}\delta \mathrm{D} \\
\text { measured }\end{array}$ & $\begin{array}{c}\delta \mathrm{D} \\
\text { calculated }\end{array}$ & $\begin{array}{c}\mathrm{Cl} \\
\text { measured }\end{array}$ & $\begin{array}{c}\mathrm{Cl} \\
\text { calculated }\end{array}$ & $\begin{array}{l}\text { Travel Time } \\
\text { (years) }\end{array}$ & $\begin{array}{c}\text { Ignored by } \\
\text { Model }\end{array}$ \\
\hline & Indian Springs & ER-5-4 \#2 & Army \#1 & & & & & & & & \\
\hline conservative & 0.66 to 0.73 & 0.27 to 0.34 & Water Well & & & & & & & & \\
\hline \multirow[t]{3}{*}{ NETPATH } & 0.98 & 0.02 & & -6.2 & -6.6 & -101.1 & -100.7 & 20.0 & 4.3 & 4,800 & \\
\hline & 0.93 & 0.07 & & -6.2 & -6.4 & -101.1 & -100.8 & 20.0 & 6.7 & 4,500 & \\
\hline & 0.91 & 0.09 & & -6.2 & -6.2 & -101.1 & -100.8 & 20.0 & 7.7 & 4,300 & \\
\hline \multirow[t]{2}{*}{ with deuterium } & no reasonable mod & & & & & & & & & & \\
\hline & Cold Creek Spring & ER-5-4 \#2 & $\begin{array}{l}\text { Army \#1 } \\
\text { Water Well }\end{array}$ & & & & & & & & \\
\hline conservative & 0.66 to 0.73 & 0.27 to 0.34 & & & & & & & & & \\
\hline \multirow[t]{2}{*}{ NETPATH } & 0.93 & 0.07 & & -6.2 & -8.5 & -101.1 & -100.3 & 20.0 & 5.1 & & \\
\hline & 0.91 & 0.09 & & -6.2 & -8.3 & -101.1 & -100.4 & 20.0 & 6.1 & & \\
\hline with $\delta \mathrm{D}$ & \multicolumn{3}{|c|}{ no reasonable models } & & & & & & & & \\
\hline \multicolumn{12}{|l|}{ Bathtub Model } \\
\hline & ER-3-1 & UE-5 PW-3 & ER-5-3 \#2 & & & & & & & & \\
\hline conservative & 0.76 to 0.87 & 0.13 to 0.24 & & & & & & & & & \\
\hline \multirow[t]{2}{*}{ NETPATH } & 0.55 & 0.45 & & -4.4 & -3.0 & -108.0 & -106.8 & 39.0 & 27.7 & & \\
\hline & 0.57 & 0.43 & & -4.4 & -3.1 & -108.0 & -106.9 & 39.0 & 28.4 & & 1 \\
\hline \multirow[t]{2}{*}{ with $\delta \mathrm{D}$} & no reasonable mode & & & & & & & & & & \\
\hline & ER-3-1 & UE-5 PW-3 & $\begin{array}{l}\text { Water Well } \\
\text { C-1 }\end{array}$ & & & & & & & & \\
\hline conservative & 0.70 & 0.30 & & & & & & & & & \\
\hline NETPATH & 0.70 & 0.30 & & -3.5 & -3.0 & -107.8 & -107.7 & 33.0 & 32.9 & 5,800 & \\
\hline with $\delta \mathrm{D}$ & 0.72 & 0.28 & & -3.5 & -3.0 & -107.8 & -107.8 & 33.0 & 33.6 & 5,500 & 2 \\
\hline
\end{tabular}

${ }^{1} 0.03 \mathrm{mmole} / \mathrm{kg}$ calcite dissolves

${ }^{2}<0.05 \mathrm{mmole} / \mathrm{kg}$ of $\mathrm{NaCl}$ and TmPbfeldspar or TmPbglass precipitates 
Table 7. Summary of conservative mixing and geochemical models (continued).

\begin{tabular}{|c|c|c|c|c|c|c|c|c|c|c|c|c|}
\hline \multicolumn{5}{|l|}{ Bathtub Model } & $\begin{array}{c}\delta^{13} \mathrm{C} \\
\text { measured }\end{array}$ & $\begin{array}{c}\delta^{13} \mathrm{C} \\
\text { calculated }\end{array}$ & $\begin{array}{c}\delta \mathrm{D} \\
\text { measured }\end{array}$ & $\begin{array}{c}\delta \mathrm{D} \\
\text { calculated }\end{array}$ & $\begin{array}{c}\mathrm{Cl} \\
\text { measured }\end{array}$ & $\begin{array}{c}\mathrm{Cl} \\
\text { calculated }\end{array}$ & $\begin{array}{l}\text { Travel Time } \\
\text { (years) }\end{array}$ & $\begin{array}{l}\text { Ignored by } \\
\text { Model }\end{array}$ \\
\hline & ER-3-1 & $\begin{array}{l}\text { UE-5C } \\
\text { Water Well }\end{array}$ & \multicolumn{2}{|l|}{$\begin{array}{l}\text { USGS Water } \\
\text { Well C }\end{array}$} & & & & & & & & \\
\hline conservative & 0.70 & 0.30 & & & & & & & & & & \\
\hline NETPATH & \multicolumn{4}{|c|}{ no reasonable models } & & & & & & & & \\
\hline \multirow[t]{2}{*}{ with $\delta \mathrm{D}$} & \multicolumn{4}{|c|}{ no reasonable models } & & & & & & & & \\
\hline & ER-3-1 & $\begin{array}{l}\text { USGS } \\
\text { HTH \#3 }\end{array}$ & ER-5-3 \#2 & & & & & & & & & \\
\hline conservative & 0.77 & 0.23 & & & & & & & & & & \\
\hline NETPATH & 0.47 & 0.53 & & & -4.4 & -4.4 & -108.0 & -106.3 & 39.0 & 32.5 & & 3 \\
\hline \multirow[t]{2}{*}{ with $\delta \mathrm{D}$} & \multicolumn{4}{|c|}{ no reasonable models } & & & & & & & & \\
\hline & ER-5-3 \#2 & $\begin{array}{l}\text { Indian } \\
\text { Springs }\end{array}$ & $\begin{array}{l}\text { Cane } \\
\text { Spring }\end{array}$ & $\begin{array}{l}\text { Army \#1 } \\
\text { Water Well }\end{array}$ & & & & & & & & \\
\hline \multicolumn{13}{|c|}{ North-to-south Flow in the LCA } \\
\hline conservative & 0.36 to 0.40 & 0.43 to 0.48 & 0.11 to 0.21 & & & & & & & & & \\
\hline \multirow[t]{3}{*}{ NETPATH } & 0.10 & 0.68 & 0.21 & & -6.2 & -7.2 & -101.1 & -98.1 & 20.0 & 10.8 & & \\
\hline & 0.10 & 0.90 & 0.00 & & -6.2 & -6.9 & -101.1 & -101.6 & 20.0 & 7.3 & 4,200 & \\
\hline & 0.14 & 0.63 & 0.23 & & -6.2 & -7.0 & -101.1 & -99.4 & 20.0 & 13.2 & 13,000 & \\
\hline \multirow[t]{3}{*}{ with $\delta \mathrm{D}$} & 0.08 & 0.91 & 0.01 & & -6.2 & -7.0 & -101.1 & -101.2 & 20.0 & 6.3 & 5,500 & \\
\hline & 0.11 & 0.85 & 0.04 & & -6.2 & -6.9 & -101.1 & -101.1 & 20.0 & 8.0 & 6,300 & \\
\hline & ER-5-3 \#2 & $\begin{array}{l}\text { Cold } \\
\text { Creek Spring }\end{array}$ & $\begin{array}{l}\text { Cane } \\
\text { Spring }\end{array}$ & $\begin{array}{l}\text { Army \#1 } \\
\text { Water Well }\end{array}$ & & & & & & & & \\
\hline conservative & 0.36 to 0.40 & 0.43 to 0.48 & 0.11 to 0.21 & & & & & & & & & \\
\hline NETPATH & 0.06 & 0.94 & 0.00 & & -6.2 & -8.6 & -101.1 & -100.7 & 20.0 & 3.8 & & \\
\hline \multirow[t]{2}{*}{ with $\delta \mathrm{D}$} & \multicolumn{4}{|c|}{ no reasonable models } & & & & & & & & \\
\hline & ER-5-3 \#2 & $\begin{array}{l}\text { Indian } \\
\text { Springs }\end{array}$ & $\begin{array}{l}\text { Quartz } \\
\text { Spring }\end{array}$ & $\begin{array}{l}\text { Army \#1 } \\
\text { Water Well }\end{array}$ & & & & & & & & \\
\hline conservative & 0.36 to 0.40 & 0.43 to 0.48 & 0.11 to 0.21 & & & & & & & & & \\
\hline NETPATH & 0.03 & 0.89 & 0.08 & & -6.2 & -7.8 & -101.1 & -99.7 & 20.0 & 7.2 & & \\
\hline \multirow{3}{*}{ with $\delta \mathrm{D}$} & 0.05 & 0.86 & 0.09 & & -6.2 & -7.7 & -101.1 & -99.7 & 20.0 & 8.2 & & \\
\hline & 0.07 & 0.92 & 0.01 & & -6.2 & -7.1 & -101.1 & -101.1 & 20.0 & 6.2 & 6,000 & \\
\hline & 0.09 & 0.89 & 0.02 & & -6.2 & -7.0 & -101.1 & -101.1 & 20.0 & 7.2 & 6,800 & \\
\hline
\end{tabular}

${ }^{3} 0.14 \mathrm{mmol} / \mathrm{kg}$ calcite precipitates 
Table 7. Summary of conservative mixing and geochemical models (continued).

\begin{tabular}{|c|c|c|c|c|c|c|c|c|c|c|c|c|}
\hline \multicolumn{5}{|c|}{ North-to-south Flow in the LCA } & \multirow{2}{*}{$\begin{array}{c}\delta^{13} \mathrm{C} \\
\text { measured }\end{array}$} & \multirow{2}{*}{$\begin{array}{c}\delta^{13} \mathrm{C} \\
\text { calculated }\end{array}$} & \multirow{2}{*}{$\begin{array}{c}\delta \mathrm{D} \\
\text { measured }\end{array}$} & \multirow{2}{*}{$\begin{array}{c}\delta \mathrm{D} \\
\text { calculated }\end{array}$} & \multirow{2}{*}{$\begin{array}{c}\mathrm{Cl} \\
\text { measured }\end{array}$} & \multirow{2}{*}{$\begin{array}{c}\mathrm{Cl} \\
\text { calculated }\end{array}$} & \multirow{2}{*}{$\begin{array}{l}\text { Travel Time } \\
\text { (years) }\end{array}$} & \multirow{2}{*}{$\begin{array}{c}\text { Ignored by } \\
\text { Model }\end{array}$} \\
\hline & ER-5-3 \#2 & $\begin{array}{l}\text { Cold Creek } \\
\text { Spring }\end{array}$ & $\begin{array}{l}\text { Quartz } \\
\text { Spring }\end{array}$ & $\begin{array}{l}\text { Army \#1 } \\
\text { Water Well }\end{array}$ & & & & & & & & \\
\hline conservative & 0.36 to 0.40 & 0.43 to 0.48 & 0.11 to 0.21 & & & & & & & & & \\
\hline NETPATH & 0 & 0.87 & 0.13 & & -6.2 & -9.7 & -101.1 & -98.4 & 20.0 & 6.4 & & \\
\hline \multirow[t]{2}{*}{ with $\delta \mathrm{D}$} & no reasonable $\mathrm{m}$ & & & & & & & & & & & \\
\hline & USGS HTH \#3 & $\begin{array}{l}\text { Indian } \\
\text { Springs }\end{array}$ & $\begin{array}{l}\text { Cane } \\
\text { Spring }\end{array}$ & $\begin{array}{l}\text { Army \#1 } \\
\text { Water Well }\end{array}$ & & & & & & & & \\
\hline conservative & 0.67 to 0.70 & 0.15 & 0.14 to 0.19 & & & & & & & & & \\
\hline NETPATH & 0.38 & 0.58 & 0.04 & & -6.2 & -8.4 & -101.1 & -101.3 & 20.0 & 11.5 & & \\
\hline \multirow[t]{2}{*}{ with $\delta \mathrm{D}$} & 0.37 & 0.57 & 0.06 & & -6.2 & -8.4 & -101.1 & -101.1 & 20.0 & 11.7 & & \\
\hline & USGS HTH \#3 & $\begin{array}{l}\text { Cold Creek } \\
\text { Spring }\end{array}$ & $\begin{array}{l}\text { Cane } \\
\text { Spring }\end{array}$ & $\begin{array}{l}\text { Army \#1 } \\
\text { Water Well }\end{array}$ & & & & & & & & \\
\hline conservative & 0.67 to 0.71 & 0.13 to 0.14 & 0.14 to 0.20 & & & & & & & & & \\
\hline \multirow[t]{2}{*}{ NETPATH } & 0.32 & 0.48 & 0.20 & & -6.2 & -9.1 & -101.1 & -99.2 & 20.0 & 12.5 & & \\
\hline & 0.41 & 0.59 & 0.00 & & -6.2 & -9.3 & -101.1 & -101.6 & 20.0 & 10.4 & & \\
\hline \multirow[t]{2}{*}{ With $\delta \mathrm{D}$} & 0.39 & 0.57 & 0.04 & & -6.2 & -9.3 & -101.1 & -101.1 & 20.0 & 10.8 & & \\
\hline & USGS HTH \#3 & $\begin{array}{l}\text { Indian } \\
\text { Springs }\end{array}$ & $\begin{array}{l}\text { Quartz } \\
\text { Spring }\end{array}$ & $\begin{array}{l}\text { Army \#1 } \\
\text { Water Well }\end{array}$ & & & & & & & & \\
\hline conservative & 0.67 to 0.70 & 0.15 & 0.14 to 0.19 & & & & & & & & & \\
\hline NETPATH & 0.03 & 0.83 & 0.14 & & -6.2 & -8.3 & -101.1 & -98.7 & 20.0 & 8.8 & & \\
\hline \multirow[t]{2}{*}{ with $\delta \mathrm{D}$} & 0.29 & 0.68 & 0.03 & & -6.2 & -8.3 & -101.1 & -101.1 & 20.0 & 10.1 & & \\
\hline & USGS HTH \#3 & $\begin{array}{l}\text { Cold Creek } \\
\text { Spring }\end{array}$ & $\begin{array}{l}\text { Quartz } \\
\text { Spring }\end{array}$ & $\begin{array}{l}\text { Army \#1 } \\
\text { Water Well }\end{array}$ & & & & & & & & \\
\hline conservative & 0.67 to 0.70 & 0.15 & 0.14 to 0.19 & & & & & & & & & \\
\hline \multirow[t]{3}{*}{ NETPATH } & 0.41 & 0.59 & 0.00 & & -6.2 & -9.3 & -101.1 & -101.8 & 20.0 & 10.4 & & \\
\hline & 0.00 & 0.97 & 0.03 & & -6.2 & -8.4 & -101.1 & -100.3 & 20.0 & 2.7 & & \\
\hline & 0.00 & 0.87 & 0.13 & & -6.2 & -9.7 & -101.1 & -98.4 & 20.0 & 6.4 & & \\
\hline with $\delta \mathrm{D}$ & 0.35 & 0.63 & 0.02 & & -6.2 & -9.4 & -101.1 & -101.1 & 20.0 & 9.8 & & \\
\hline
\end{tabular}


For a NETPATH or PHREEQC model to be considered valid, the final mixed waters were required to have calculated $\delta \mathrm{D}$ within $3 \%$ of the measured $\delta \mathrm{D}$ of the final water, and calculated $\mathrm{Cl}$ concentrations equal to, or less than, the measured concentration of the final water. The latter requirement assumes that a Cl-containing phase is present along the flowpath and that this phase may dissolve, adding $\mathrm{Cl}$ to the groundwater. If these criteria are met, then the mixing and mass-balance calculations performed are checked for validity against mineral saturation indicies. For a model to be valid, only minerals that are undersaturated can dissolve and only minerals that are above saturation can either precipitate or form by incongruent dissolution of another phase that is below saturation. If any of these criteria are not met, then the model is considered to be invalid. The amount of mineral precipitation or dissolution is determined by the net change in water chemistry along a flowpath while considering geochemical reactions along the same flowpath. These models do not calculate the amount of mineral dissolution or precipitation needed to reach mineral saturation; rather, the models use the measured water chemistry and calculate the amount of mineral dissolution or precipitation needed to explain the difference in measured water chemistry between the initial and final waters. Mineral saturation indices for all of the groundwater samples considered in these models are listed in Table 8.

Table 8. NETPATH thermodynamic speciation calculations. Values are saturation indices: negative values indicate undersaturation and positive values indicate oversaturation.

\begin{tabular}{lcccccccc}
\hline \multicolumn{1}{c}{ Site Name } & Calcite & $\begin{array}{c}\mathrm{SiO}_{2} \\
\text { (Chalcedony) }\end{array}$ & Albite & Anorthite & K-feldspar & Ca-smectite & Illite & Dolomite \\
\hline Army \#1 Water Well & -0.04 & -0.02 & -2.56 & -4.37 & -1.14 & 1.80 & -0.51 & 0.01 \\
ER-3-1 & 0.12 & 0.20 & -0.57 & -1.75 & 0.75 & 3.90 & 3.00 & 0.28 \\
UE-5 PW-3 & 0.18 & 0.63 & 0.21 & -2.64 & 1.49 & 2.46 & 2.23 & 0.22 \\
Water Well C-1 & -0.07 & 0.13 & -1.53 & -3.36 & -0.26 & 2.06 & 1.12 & -0.11 \\
USGS Water Well C & 0.92 & 0.26 & -0.69 & -2.84 & 0.67 & 1.62 & 1.48 & 1.77 \\
ER-5-3 \#2 & 0.54 & 0.15 & -1.77 & -4.16 & -0.42 & 0.24 & -0.19 & 1.09 \\
ER-5-4 \#2 & -0.43 & 0.43 & -0.14 & -4.75 & 0.40 & -1.07 & -0.88 & -1.02 \\
Indian Springs & -0.06 & -0.11 & -3.28 & -3.71 & -1.45 & 1.16 & 0.13 & -0.02 \\
Cold Creek Spring & 0.42 & -0.20 & -2.79 & -2.38 & -0.78 & 3.09 & 2.00 & 0.35 \\
Cane Spring & -0.07 & 0.70 & 0.59 & -2.06 & 2.23 & 4.82 & 4.16 & -0.51 \\
USGS HTH \#3 & 0.22 & -0.10 & -2.19 & -3.73 & -0.90 & 0.29 & -0.18 & 0.48 \\
Quartz Spring & 0.08 & 0.73 & 0.98 & -1.87 & 2.06 & 5.97 & 4.85 & 0.04 \\
\hline
\end{tabular}

For a valid geochemical model along a given flowpath, the groundwater travel time for the mixture was calculated when the calculated $\delta^{13} \mathrm{C}$ was within $1 \%$ of the final downgradient water. Travel times were calculated using the average $\delta^{13} \mathrm{C}$ of calcite found in alluvium (-3.11\%o excluding clasts of limestone), volcanic rocks $(-2.86 \%$ ), and carbonate rocks $(0.41 \%)$, depending on the hydrostratigraphic units the groundwater was flowing through (Table 4). For example, the average $\delta^{13} \mathrm{C}$ of calcite for water flowing through volcanic and carbonate rocks is $-1.23 \%$. An average $\delta^{13} \mathrm{C}$ composition of $0.22 \%$ was used for dolomite in the models (Table 4), which is similar to the $0.0 \%$ value determined for dolomite in the LCA of southern Nevada by Thomas et al. (1996).

Although the analytical precision for ${ }^{14} \mathrm{C}$ activity is quite good (one percent modern carbon [pmc]), because of radioactive decay, the error of calculated groundwater ages varies with the amount of ${ }^{14} \mathrm{C}$ measured. For example, a groundwater with $50 \mathrm{pmc}$ has an age error of \pm 165 years, while a groundwater with 10 pmc would have an age error of \pm 829 year. 
Groundwater in the Frenchman Flat area generally contains very low amounts of ${ }^{14} \mathrm{C}$ $(<10 \mathrm{pmc})$ so modeling usually results in very small differences in age between upgradient and downgradient groundwaters. These small differences in age along a flowpath are compounded when several initial upgradient waters with low ${ }^{14} \mathrm{C}$ are mixed together, resulting in errors of several thousands of years for the initial mixture. Therefore, in Frenchman Flat, modeled ${ }^{14} \mathrm{C}$ groundwater ages usually have large errors associated with them and should be viewed cautiously.

Additionally, models with calculated $\delta^{13} \mathrm{C}$ values greater than or equal to $1 \%$ of the final downgradient water indicated a poor representation of the reactions for the carboncontaining phases along these flowpaths. Carbon-14 ages for these models were not calculated. Carbon-13 values that vary by $1 \%$ or more than measured values indicate that (1) the carbon-containing phases in the model are not all accounted for; (2) the $\delta^{13} \mathrm{C}$ values used for calcite and dolomite in the models are not representative of the rock units or they have greater variability than measured; (3) the groundwaters chosen for the models are not representative of the actual mixture; or (4) some combination of the above factors.

Mixing models were tested using PHREEQC when NETPATH produced significantly different mixing percentages than conservative tracer modeling, or when NETPATH did not produce any models for valid conservative tracer models. PHREEQC models included all the major-ion chemistry plus $\delta \mathrm{D}$ and the same phases as used in NETPATH. All models allowed a solution error (variability) of 10 percent for all major-ion chemistry and three percent for $\delta \mathrm{D}$ (about 3\%). Occasionally, individual ion variability was increased to more than 10 percent to achieve a PHREEQC model solution, but only for ions with concentrations of less than $10 \mathrm{mg} / \mathrm{L}$. Increasing the variability for low-concentration ions prevents low-ion concentrations from eliminating potential models where small amounts of mass transfer quickly exceed the allowed solution error.

\section{Geochemical Modeling Results}

The following section describes the NETPATH and PHREEQC geochemical modeling results for the sources, mixtures, and flowpaths identified in the conservative tracer modeling. For ease of comparison, Table 7 combines the results of the geochemical models with the conservative tracer models.

North-to-south Flow

Conservative tracer modeling showed that a southern pathway from the alluvial aquifer to the LCA is unlikely. However, conservative tracer modeling did indicate that a north-to-south flowpath from the deep volcanic aquifer to the LCA is possible with a mixture of Indian Springs (Spring Mountains recharge) with ER-5-4 \#2 to produce Army \#1 Water Well water. Conservative tracers predict a mixture of 66 to 73 percent Indian Springs with 27 to 34 percent ER-5-4 \#2 to produce Army \#1 Water Well. Strontium isotopic and concentration data are inconsistent with a simple mixing model and would require the addition of substantial amounts of radiogenic Sr to produce Army \#1 Water Well. The most reasonable geochemical models for this mixture of waters produce a mixture of 91 to 98 percent Spring Mountains recharge (Indian or Cold Creek springs) with two to nine percent ER-5-4 \#2 to produce Army \#1 Water Well (Table 7). Indian Springs and Army \#1 Water Well are saturated with respect to calcite (saturation is assumed for saturation index [SI] values of \pm 0.1 ), whereas ER-5-4 \#2 is undersaturated with respect to calcite (Table 8). Thus, calcite could either dissolve or 
precipitate in the geochemical models (Appendix B). However, the large percentage of calcite-saturated water represented by the Indian Springs component would require that calcite (or other Sr-bearing phases) in the volcanic aquifer would have to dissolve to supply the radiogenic Sr characteristics observed in Army \#1 Water Well. This scenario is unlikely given the general nonradiogenic nature of $\mathrm{Sr}$ observed in other samples from the volcanic aquifer. Furthermore, when $\delta \mathrm{D}$ was included in the NETPATH model as a conservative mixing component, no reasonable models were found.

Modeling results and travel time calculations for north-to-south flow are summarized in Table 7. Details of the geochemical models are presented in Appendix B. Taking into account all valid models determined from both the conservative tracers and geochemical modeling, mixing ratios for north-to-south flow are 66 to 98 percent Indian Springs with two to 34 percent ER-5-4 \#2 to produce Army \#1 Water Well chemistry and isotopic composition. A NETPATH model-calculated groundwater travel time for the mixture of groundwaters flowing to Army \#1 Water Well ranged from 4,300 to 4,800 years. PHREEQC modeling results, with the error limits described previoulsy, did not produce any additional models not already produced by conservative tracers and NETPATH.

West-to-east Flow

Available water chemistry and isotopic data do not support a west-to-east flowpath in the alluvial or volcanic aquifers in Frenchman Flat to the LCA, so no geochemical models were developed for this flowpath.

Bathtub Model

The potential for vertical leakage of groundwater from the overlying aquifers to the LCA can only be addressed at one location within the Frenchman Flat basin - at well ER-5-3 \#2. The conservative tracer models used several different mixtures of groundwater to evaluate leakage of groundwater from the alluvium to the LCA. First, the most concentrated groundwater end-member in the LCA, ER-3-1 to the north of Frenchman Flat in eastern Yucca Flat, was mixed with UE-5 PW-3, completed in the volcanic TMA, to produce the observed water chemistry at ER-5-3 \#2 in the LCA in Frenchman Flat. The conservative tracer models resulted in a mixture of 76 to 87 percent ER-3-1 with 13 to 24 percent UE-5 PW-3 to produce ER-5-3 \#2. Strontium data indicated that no vertical flow was occurring from the alluvial and volcanic rock aquifers into the LCA in the Frenchman Flat area. Geochemical models for this mixture of waters produced a mixture of 55 to 57 percent ER-3-1 with 43 to 45 percent UE-5 PW-3 to produce ER-5-3 \#2 (Table 7). Model solutions were obtained by allowing a very small amount of calcite $(0.05$ millimoles per liter) to dissolve, although all waters were above saturation with respect to calcite (Table 8 ). When $\delta \mathrm{D}$ was included in the NETPATH model as a conservative mixing component, no reasonable models were found.

Modeling results for this vertical flow mixture are summarized in Table 7. Details of all models that were tested are presented in Appendix B. Taking into account all valid models determined from both conservative tracers and geochemical modeling, mixing ratios for vertical flow are 55 to 87 percent ER-3-1 with 13 to 45 percent UE-5 PW-3 to produce ER-5-3 \#2. Strontium isotopic data indicate that vertical flow is unlikely. Thus, vertical flow from the volcanic aquifer to the LCA in Frenchman Flat for this one mixture at ER-5-3 \#2 ranges from zero to 45 percent. Carbon-14 groundwater travel-times for this mixture of 
groundwater were not calculated because modeled $\delta^{13} \mathrm{C}$ values are isotopically enriched relative to measured values. The lack of agreement between measured and calculated $\delta^{13} \mathrm{C}$ values suggests that the carbon fluxes in the model are poorly constrained, the $\delta^{13} \mathrm{C}$ values of the carbon-containing phases may be different than those measured in Table 6, or this combination of groundwaters does not characterize this flowpath. PHREEQC modeling results produced no additional models not already produced by conservative tracers and NETPATH.

In the conservative tracer modeling, USGS Water Well $\mathrm{C}$ and Water Well C-1 were substituted for well ER-5-3 \#2. These wells are not located in Frenchman Flat, but rather are LCA wells just north of Frenchman Flat in Yucca Flat. Using these wells as the downgradient final water instead of ER-5-3 \#2 results in a mixture of 30 percent UE-5 PW-3 with 70 percent ER-3-1 (Table 7). Again, Sr indicated no vertical flow when these wells were substituted for ER-5-3 \#2. NETPATH modeling produced no valid models for mixing UE-5 PW-3 with ER-3-1 to produce USGS Water Well C. NETPATH modeling produced a mixture of 70 percent ER-3-1 with 30 percent UE-5 PW-3 to produce Water Well C-1. When $\delta \mathrm{D}$ was included in the NETPATH model as a conservative mixing component, models similar to those without $\delta$ D were produced for the ER-3-1 and UE-5 PW-3 mixture making Water Well $\mathrm{C}-1$. However, the models including $\delta \mathrm{D}$ always contained at least two phases with small amounts of mass transfer $(<0.05$ millimoles $)$ out of solution that should have been dissolving. NETPATH modeling produced the same mixing percentages of water for producing Water Well $\mathrm{C}-1$ as that of the conservative tracer models. A model-calculated groundwater travel time for the mixture of groundwaters flowing to Water Well $\mathrm{C}-1$ is from 5,500 to 5,800 years. PHREEQC modeling did not produce any additional valid models.

Another potential mixture of waters identified by conservative tracer modeling that could produce ER-5-3 \#2 includes only LCA waters with no vertical leakage. This mixture of LCA waters used ER-3-1 and USGS HTH \#3 to produce the water chemistry observed at ER-5-3 \#2. Well ER-3-1 was chosen to represent groundwater in Yucca Flat that flows southward into Frenchman Flat, while USGS HTH \#3 was used to represent groundwater flowing westward into Frenchman Flat. The conservative tracer model resulted in a mixture of 77 percent ER-3-1 with 23 percent USGS HTH \#3 to produce ER-5-3 \#2. Using Sr data, a mixture of about 40 percent ER-3-1 with 60 percent USGS HTH \#3 produces the ${ }^{87} \mathrm{Sr} /{ }^{86} \mathrm{Sr}$ value in wells ER-5-3 \#2, USGS Water Well C, and Water Well C-1. NETPATH modeling for this same mixture of waters resulted in a mixture of 47 percent ER-3-1 with 53 percent USGS HTH \#3 to produce ER-5-3 \#2. The best NETPATH model solution had a small amount of calcite $(0.14$ millimoles per $\mathrm{kg})$ precipitating, although all waters were above saturation with respect to calcite (Table 8). USGS HTH \#3 has a high ${ }^{14} \mathrm{C}$ activity $(36.9 \mathrm{pmc})$ as compared to all other LCA groundwaters in Frenchman Flat and nearby areas $(<10 \mathrm{pmc})$. There is only one ${ }^{14} \mathrm{C}$ sample from USGS HTH \#3, a bailed sample, so it is possible that the measured ${ }^{14} \mathrm{C}$ activity of this sample is not accurate. Because of the questionable ${ }^{14} \mathrm{C}$ in USGS HTH \#3, a groundwater travel time for this model was not calculated. When $\delta \mathrm{D}$ was included in the NETPATH model as a conservative mixing component, no reasonable models were found. PHREEQC modeling did not produce any additional valid models.

In summary, the conservative tracer and geochemical models developed to evaluate vertical leakage from the overlying alluvium and volcanic rock aquifers into the LCA show vertical leakage ranging from zero to 45 percent. The upper limit of this mixture is not 
supported by conservative tracers, which show an upper limit of 30 percent vertical leakage. The lower limit of this range, zero percent, is supported by the $\mathrm{Sr}$ isotopic and concentration data and by major-ion chemistry in the LCA beneath Frenchman Flat, which can be derived entirely from mixing with other LCA groundwaters with no vertical leakage from overlying alluvial and volcanic aquifers.

North-to-south Flow in the LCA

Conservative tracer modeling was also used to investigate the flow of groundwater in the LCA from Frenchman Flat to the southwest. The first available well with chemical and isotopic data downgradient of Frenchman Flat is Army \#1 Water Well. The conservative tracer modeling considered previous investigations that indicated groundwater beneath Frenchman Flat (ER-5-3 \#2, USGS Water Well C, Water Well C-1, USGS HTH \#3) flows southwest out of Frenchman Flat and mixes with groundwater recharged in the Spring Mountains before it reaches Army \#1 Water Well (Winograd and Thordarson, 1975; Thomas et al., 1996; Hershey and Acheampong, 1997). Indian Springs and Cold Creek Spring are used to represent Spring Mountains recharge flowing to Army \#1 Water Well. Additionally, the conservative tracers indicate that a third source of groundwater, with enriched $\delta \mathrm{D}$ and $\delta^{18} \mathrm{O}$, is needed to produce the observed values at Army \#1 Water Well if any significant amount of Frenchman Flat groundwater is added to Spring Mountains recharge. This isotopically enriched groundwater was modeled using different perched springs as a local recharge end member in the conservative tracer modeling. These perched springs include Cane Spring, west of Frenchman Flat, and Quartz Spring in the Pintwater Range, east of Frenchman Flat.

The conservative tracer modeling produced significantly different results for the mixture depending upon which well was used to represent Frenchman Flat LCA Water (ER-5-3 \#2, USGS Water Well C, Water Well C-1 or USGS HTH \#3). First, using ER-5-3 \#2 as the LCA water, a mixture of 36 to 40 percent Frenchman Flat LCA with 43 to 48 percent Spring Mountains and 11 to 21 percent local recharge produced Army \#1 Water Well. Second, using USGS HTH \#3 as the LCA water, a mixture of 67 to 71 percent Frenchman Flat LCA with 13 to 15 percent Spring Mountains and 14 to 20 percent local recharge produced Army \#1 Water Well. When using $\mathrm{Sr}$ data, three-component mixing with USGS HTH \#3 representing Frenchman Flat LCA water, 10 to 20 percent USGS HTH \#3 with Spring Mountains and local recharge varying between zero and 100 percent produced Army \#1 Water Well. NETPATH models using these three sources of water, with ER-5-3 \#2 as the Frenchman Flat LCA water, produces a mixture of zero to 14 percent Frenchman Flat LCA with 63 to 94 percent Spring Mountains and zero to 23 percent local recharge for Army \#1 Water Well (Table 7). When USGS HTH \#3 is used as the Frenchman Flat LCA source, then the NETPATH mixture of waters ranges from zero to 41 percent Frenchman Flat LCA with 48 to 97 percent Spring Mountains and zero to 20 percent local recharge. These ranges of mixture include NETPATH models both with and without $\delta \mathrm{D}$.

Calculated $\delta^{13} \mathrm{C}$ values were within 1\%o for two of the NETPATH modeled mixtures so groundwater travel times could be calculated for these mixtures. For the mixtures of ER-5-3 \#2, Indian Springs, and Cane Springs producing Army \#1 Water Well, calculated groundwater travel times ranged from 4,200 to 6,300 years when the local recharge component from Cane Spring was very small (zero to four percent) and the Spring Mountains component was large (85 to 91 percent). One mixture, with much more Cane Spring local 
recharge component (23 percent) and less Spring Mountains (63 percent), produced a much longer travel time, 13,000 years. This substantially longer travel time results from the larger proportion of local recharge, which has a high ${ }^{14} \mathrm{C}$ (Cane Spring $=92.8 \mathrm{pmc}$ ). This longer travel time should be viewed cautiously since the local recharge component (23 percent) would appear to be rather large.

Calculated travel times for the other valid NETPATH models ranged from 6,000 to 6,800 years for the mixture of ER-5-3 \#2, Indian Springs, and Quartz Spring as the local recharge component. As with the other shorter travel times above, where the Spring Mountains water is the principal component of Army \#1 Water Well (86 to 92 percent), the local recharge component using Quartz Spring is smaller (one to nine percent). For all of the models with calculated travel times, the component from Frenchman Flat making Army \#1 Water Well was relatively small, ranging from three to 14 percent. For the remainder of the NETPATH models, the calculated $\delta^{13} \mathrm{C}$ values were lighter (more negative: -9.7 to $-7.2 \%$ ) than the measured value at Army \#1 Water Well (-6.2\%) indicating that the carbon fluxes in the model are poorly constrained, the $\delta^{13} \mathrm{C}$ values of the carbon-containing phases may be different than those measured, or this combination of groundwaters does not represent this flowpath.

In summary, the conservative tracer modeling, Sr isotopic and concentration data, and geochemical modeling evaluating flow from Frenchman Flat to the southwest in the LCA show that, depending on the Frenchman Flat LCA water used in the evaluation, the amounts of Spring Mountains and local recharge water vary significantly. First, if ER-5-3 \#2 is used to represent Frenchman Flat LCA water, a mixture of zero to 40 percent Frenchman Flat LCA with 43 to 94 percent Spring Mountains and zero to 23 percent local recharge is needed to produce the water at Army \#1 Water Well. Second, if USGS HTH \#3 is chosen to represent Frenchman Flat LCA, then a mixture of zero to 71 percent Frenchman Flat LCA with 13 to 97 percent Spring Mountains and zero to 20 percent local recharge is needed to produce the water at Army \#1 Water Well (not including the Sr data that produced a range of zero to 100 percent for Spring Mountains and local recharge in the mixture). PHREEQC modeling results did not produce any additional models not already produced by conservative tracers and NETPATH.

Geochemical Models and Travel Times for Proposed Flowpaths - Summary

The NETPATH program models changes in major-ion chemistry along a flowpath and calculates groundwater-mixing ratios on the basis of chemical mass-balance relationships. The resulting geochemical models generated during this study are not always consistent with conservative tracer models presented earlier in this report. This variation reflects differences in the approach of two modeling techniques, but is also consistent with the natural variability in water chemistry within the system. Whereas the mixing "end-members" used in the models are specific in composition, the groundwater compositions within each subregion of the flow system are more variable, and cannot be fully described by a few selected end-members.

The north-to-south and bathtub conceptual models had valid geochemical models. However, the west-to-east conceptual model did not have any valid geochemical models, possibly because of limited groundwater chemistry data presently available.

Groundwater travel times for mixtures of waters for vertical flowpaths in the Frenchman Flat area, flow within the LCA in the Frenchman Flat area, and flow from the 
Frenchman Flat area via the LCA to the southwest range from 4,300 to 6,800 years. One much longer calculated travel time for water flowing from Frenchman Flat to Army \#1 Water Well southwest of Frenchman Flat should be viewed with caution because of the large amount of local recharge in the mixture. Groundwater travel times were not calculated for many flowpaths because of a lack of agreement between the calculated and measured $\delta^{13} \mathrm{C}$. This result indicates that the carbonate reactions in the Frenchman Flat area are poorly constrained, most likely because of the limited sampling locations in the LCA.

\section{Groundwater Age Estimates from DOC Carbon-14}

Groundwater samples for DOC analysis were collected from select locations and analyzed for $\delta^{13} \mathrm{C}$ and ${ }^{14} \mathrm{C}$. These data provide an independent estimate of groundwater age that can be compared with groundwater travel times calculated using $\mathrm{DI}^{14} \mathrm{C}$ data. Whereas $\mathrm{DI}^{14} \mathrm{C}$ travel times represent the mean groundwater transit time along a flowpath, $\mathrm{DO}{ }^{14} \mathrm{C}$ groundwater ages more closely reflect the average time elapsed since groundwater recharged. Thus, $\mathrm{DO}^{14} \mathrm{C}$ ages should be the same or greater for $\mathrm{DI}^{14} \mathrm{C}$ ages. Because the volcanic and carbonate aquifers in southern Nevada have very low organic content, $\mathrm{DO}^{14} \mathrm{C}$ ages are not affected by water-rock reactions as $\mathrm{DI}^{14} \mathrm{C}$ groundwater travel times are, so the $\mathrm{DO}^{14} \mathrm{C}$ ages do not have to be corrected for these reactions.

Calculated $\mathrm{DO}^{14} \mathrm{C}$ ages are presented in Table $9 . \mathrm{DO}^{14} \mathrm{C}$ ages range from 3,000 to 14,000 years for groundwater in the Frenchman Flat area. These ages assume that an initial $\mathrm{DO}^{14} \mathrm{C}$ value (during recharge) is similar to that measured in wells UE-29a \#1 and UE-29a \#2 in Fortymile Wash. The Fortymile Wash samples are used to represent recharge $\mathrm{DO}^{14} \mathrm{C}$ because they are the only modern $\mathrm{DO}^{14} \mathrm{C}$ samples on the NTS. The average $\mathrm{DO}^{14} \mathrm{C}$ age increases with depth from 4,000 years in the alluvial aquifer to 7,200 years in the volcanic aquifers to 14,000 years for well ER-5-3 \#2 in the LCA. All ages represent maximum ages since any DOC added to the groundwater by dissolution of aquifer organic matter would not contain ${ }^{14} \mathrm{C}$. Additionally, the ages reflect the travel time of groundwater from recharge areas to the Frenchman Flat area.

Table 9. Dissolved organic carbon calculated groundwater ages. Age is for an initial $\mathrm{DO}^{14} \mathrm{C}$ value of 66 pmc (average of UE-29a \#1 and \#2). Symbol: NA, not analyzed.

\begin{tabular}{|c|c|c|c|c|}
\hline Site Name & $\begin{array}{c}\mathrm{DOC} \\
(\mathrm{mg} / \mathrm{L})\end{array}$ & $\begin{array}{c}\mathrm{DO}^{13} \mathrm{C} \\
(\% \mathrm{o})\end{array}$ & $\begin{array}{c}\mathrm{DO}^{14} \mathrm{C} \\
\text { (percent modern) }\end{array}$ & $\begin{array}{l}\text { Age } \\
\text { (yrs) }\end{array}$ \\
\hline \multicolumn{5}{|c|}{ Alluvial Aquifer } \\
\hline Water Well 5A & 0.44 & -26.6 & 24.8 & 8,100 \\
\hline Water Well 5B & 0.10 & -29.1 & 42.3 & 3,700 \\
\hline Water Well 5C & 0.35 & -62.7 & 42.2 & 3,700 \\
\hline ER-5-4 & 0.19 & -29.2 & 45.9 & 3,000 \\
\hline Average & & & 38.8 & 4,400 \\
\hline \multicolumn{5}{|c|}{ Volcanic Aquifer } \\
\hline Water Well 4A & 0.20 & -46.6 & 16.1 & 12,000 \\
\hline ER-5-4 \#2 & 0.52 & -25.4 & 19.6 & 10,000 \\
\hline UE-5 PW-3 & 0.14 & -30.3 & 41.3 & 3,900 \\
\hline UE-5c Water Well & 0.17 & NA & 32.9 & 5,800 \\
\hline Average & & & 27.5 & 7,200 \\
\hline \multicolumn{5}{|c|}{ Lower Carbonate Aquifer } \\
\hline ER-5-3 \#2 & 0.61 & -36.8 & 12.0 & 14,000 \\
\hline
\end{tabular}




\section{SUMMARY}

A comparison of the isotopic signature of Frenchman Flat groundwater and recent recharge shows that most Frenchman Flat groundwater is substantially depleted isotopically relative to local recharge. Frenchman Flat groundwater also falls well off of the local meteoric water line. These data indicate that Frenchman Flat groundwater was either recharged at higher elevations outside the basin or under different climatic conditions. The only Frenchman Flat groundwater similar to local recent recharge is found in Water Well \#4 and Water Well 4A in the CP Basin.

Groundwater in and around Frenchman Flat is composed of two types of major-ion composition. A Na+K-HCO 3 type occurs in the alluvial and volcanic aquifers while a $\mathrm{Ca}+\mathrm{Mg}-\mathrm{Na}-\mathrm{HCO}_{3}$ mixed type occurs in the LCA. There is no discernible lateral or vertical spatial trend in the major-ion composition in the alluvial and volcanic aquifers in Frenchman Flat, suggesting little lateral or vertical flow in these aquifers. The lack of the $\mathrm{Ca}+\mathrm{Mg}-\mathrm{Na}-\mathrm{HCO}_{3}$ carbonate/volcanic mixed-type water in the alluvial and volcanic aquifers discounts part of the north-to-south flow conceptual model where Yucca Flat LCA groundwater would flow into the Frenchman Flat AA. Groundwater in the LCA can also be differentiated by TDS into two groups, more dilute and less dilute. The more-dilute water has equal equivalents of $\mathrm{Ca}$ and $\mathrm{Na}$, while the less-dilute water has more $\mathrm{Na}$ than $\mathrm{Ca}$. The less-dilute group may indicate older groundwater that has had more time for water-rock reactions than the more-dilute group.

Dissolved $\mathrm{Sr}$ and ${ }^{87} \mathrm{Sr} /{ }^{86} \mathrm{Sr}$ values in Frenchman Flat groundwater from alluvial and volcanic aquifers are derived from dissolution of carbonate-rich soils during recharge with additional Sr from the dissolution of silicate minerals making up the aquifer matrix. Strontium in less-dilute LCA groundwater in Frenchman and Yucca flats, Army \#1 Water Well, and Ash Meadows springs have substantially higher $\mathrm{Sr}$ concentrations and larger ${ }^{87} \mathrm{Sr} /{ }^{86} \mathrm{Sr}$ values than groundwater from the alluvial and volcanic aquifers and the Spring Mountains. Strontium/calcium ratios show that the high concentration of $\mathrm{Sr}$ in the LCA groundwater cannot be derived from bulk dissolution of marine carbonates making up the LCA. Strontium-87/strontium-86 values in less dilute LCA groundwater are more similar to ${ }^{87} \mathrm{Sr} /{ }^{86} \mathrm{Sr}$ values from UCCU rocks (Eleana Formation argillite) than LCA marine carbonates.

Analysis of conceptual flowpaths using conservative tracers was limited by an uneven spatial distribution of wells within the study area and by a paucity of wells completed in the LCA. The north-to-south flowpath within the alluvial aquifer was discounted because of a lack of spatial trends in the conservative tracers $\mathrm{Cl}, \delta \mathrm{D}$, and $\delta^{18} \mathrm{O}$. Similarly, a north-to-south flowpath from the alluvial aquifer to the LCA at Army \#1 Water Well could not be substantiated. Conservative tracers in one deep Frenchman Flat volcanic aquifer well with less dilute major-ion composition, ER-5-4 \#2, could be mixed with Spring Mountains water to produce the downgradient groundwater at Army \#1 Water Well. This mixture was roughly 70 percent Spring Mountains and 30 percent deep Frenchman Flat volcanic groundwater.

West-to-east flow in the alluvial aquifer to the LCA in eastern Frenchman Flat could not be substantiated with conservative tracers. Mixing models using groundwater from the CP Basin in western Frenchman Flat were unsuccessful because this water is isotopically heavy, similar to local recharge, and is distinct from other Frenchman Flat groundwater.

Again, because of lack of wells penetrating the LCA in Frenchman Flat, vertical leakage from the overlying alluvial and volcanic aquifers into the LCA could only be tested at 
one location. In this conceptual flowpath, 30 percent of upgradient, less dilute groundwater from Yucca Flat could be mixed with 70 percent Frenchman Flat volcanic groundwater to produce the Frenchman Flat LCA water at ER-5-3 \#2. However, this mixing model using conservative tracers was not unique as ER-5-3 \#2 water could also be produced by mixing 70 percent upgradient less-dilute Yucca Flat groundwater with 30 percent LCA water from eastern Frenchman Flat. This particular model is significant because it does not require any leakage from the overlying alluvial or volcanic aquifers to produce the Frenchman Flat LCA water.

Groundwater flow southward out of the Frenchman Flat LCA was also tested. This model required a three-component mixture to produce downgradient LCA water at Army \#1 Water Well. The three-component mixture consisted of water from Frenchman Flat LCA, the Spring Mountains, and local recharge. Different mixtures could be produced using a variety of end-member springs and wells demonstrating the nonunique nature of these conservative tracer models. The most realistic models had mixtures of approximately 40 percent Frenchman Flat LCA, 50 percent Spring Mountains, and 10 percent local recharge. However, ${ }^{36} \mathrm{Cl}$ data suggest that $\mathrm{Cl}$ may not behave conservatively in the LCA, which would result in a greater proportion of Spring Mountains groundwater and less Frenchman Flat LCA water downgradient of Frenchman Flat.

Similar to the conservative tracer modeling, Sr data do not support north-to-south flow in the alluvial aquifer or in the volcanic aquifer. Additionally, Sr data do not support deep Frenchman Flat volcanic groundwater mixing with Spring Mountains water to produce the water at Army \#1 Water Well as suggested by the conservative tracers. As with conservative tracers, Sr data do not substantiate west-to-east flow in the alluvial or volcanic aquifer to the LCA in eastern Frenchman Flat. Vertical leakage from the overlying alluvial and volcanic aquifers into the Frenchman Flat LCA also was not supported by $\mathrm{Sr}$ data. Strontium data generally support the three-component mixture of Frenchman Flat LCA, Spring Mountains, and local recharge to produce the LCA groundwater at Army \#1 Water Well and ultimately at Ash Meadows. However, Sr data do not give consistent mixing proportions, as the various mixtures are dependent on the specific end-member waters used.

Geochemical modeling of a north-to-south flowpath from the deep volcanic aquifer to the LCA, consisting of a mixture of Spring Mountains and ER-5-4 \#2 water to produce Army \#1 Water Well water, had a much greater percent of Spring Mountains water, 91 to 98 percent, and only two to nine percent ER-5-4 \#2, than conservative tracers. However, Sr data indicated that this flowpath is unlikely. Also, no reasonable geochemical models could be produced when $\delta \mathrm{D}$ was added to the simulation. A model-calculated groundwater travel time for the most reasonable geochemical models, without $\delta \mathrm{D}$, for the mixture from the deep Frenchman Flat volcanic aquifer to the LCA at Army \#1 Water Well was 4,300 to 4,800 years.

Testing of vertical leakage from the overlying aquifers to the LCA by geochemical modeling produced a mixture of approximately 55 percent ER-3-1, an upgradient Yucca Flat LCA groundwater with a less-dilute major-ion composition, with 45 percent Frenchman Flat volcanic water from UE-5 PW-3 to make ER-5-3 \#2 water. However, Sr data indicated that this mixture is unlikely and no reasonable geochemical models could be produced when $\delta \mathrm{D}$ was added to the geochemical models. Groundwater travel times were not calculated because of poor agreement between calculated and modeled $\delta^{13} \mathrm{C}$. 
Another vertical leakage scenario mixing Frenchman Flat volcanic groundwater with less dilute Yucca Flat LCA groundwater to produce Yucca Flat LCA groundwater at Water Well C-1 just north of Frenchman Flat was modeled. This mixture was modeled successfully, both with and without $\delta \mathrm{D}$, producing a mixture of 30 percent Frenchman Flat volcanic water and 70 percent less dilute Yucca Flat LCA water. However, Sr data do not support this mixture. Carbon-14 calculated groundwater travel time was about 5,700 years for the mixture of waters.

A third mixture showing no vertical leakage from Frenchman Flat alluvial and volcanic aquifers to the Frenchman Flat LCA was also developed. In this mixture, approximately 50 percent less dilute Yucca Flat LCA groundwater could be mixed with 50 percent LCA groundwater from eastern Frenchman Flat to produce the Frenchman Flat LCA groundwater at ER-5-3 \#2. However, no reasonable geochemical models were produced when $\delta \mathrm{D}$ was added as a mixing tracer. Because of a questionable ${ }^{14} \mathrm{C}$ value from the eastern LCA groundwater, USGS HTH \#3, groundwater travel times were not calculated.

Groundwater flow from the Frenchman Flat LCA southwest toward Ash Meadows was also considered. Conservative tracer modeling required a mixture of Frenchman Flat LCA, Spring Mountains groundwater, and a local recharge component to produce the downgradient water chemistry at Army \#1 Water Well. Geochemical modeling, with and without $\delta \mathrm{D}$, produced mixtures, depending on the specific locations used to represent the various components, of zero to 40 percent Frenchman Flat LCA, approximately 50 to 100 percent Spring Mountains, and zero to 20 percent local recharge. Groundwater travel times ranged from 4,300 to 6,800 years. However, not all models over the range of mixtures had travel times calculated because of disagreement between modeled and observed $\delta^{13} \mathrm{C}$. For the models with travel times, the Frenchman Flat LCA component was relatively small, from three to 14 percent, while the Spring Mountains contributed the most groundwater, 86 to 92 percent, and the local recharge component was small, one to nine percent.

Groundwater age estimates from $\mathrm{DO}^{14} \mathrm{C}$ range from 3,000 to 14,000 years in the Frenchman Flat basin. A DO ${ }^{14} \mathrm{C}$ age for a sample location is the average time elapsed for groundwater to flow from the recharge area to the sample location, whereas model-calculated $\mathrm{DI}^{14} \mathrm{C}$ travel times are the mean transit time for groundwater to flow from one sampling location to the next along a flowpath. The oldest $\mathrm{DO}^{14} \mathrm{C}$ age in Frenchman Flat is found in one of the deeper wells, the LCA-penetrating ER-5-3 \#2.

\section{CONCLUSIONS}

Analysis of the available geochemical and isotopic data, generally, did not support the present conceptual models of groundwater flow in the alluvial and volcanic aquifers in the Frenchman Flat CAU. However, geochemical and isotopic data do support migration of Frenchman Flat LCA groundwater out of the basin, southwest, toward the NTS boundary.

As a whole, conservative tracers, Sr geochemistry, and water-rock reaction modeling did not support any viable groundwater flowpaths from the alluvial or volcanic aquifers to the LCA southward, westward, or downward. In some instances, one or two methods of analysis indicated that a flowpath was reasonable, but then another data set would contradict that flowpath. In the case of the west-to-east conceptual model, none of the geochemical and isotopic data supported that flowpath. 
Geochemical and isotopic data did support movement of Frenchman Flat LCA groundwater southwestward out of the basin. This flowpath required a mixture of Frenchman Flat LCA and Spring Mountains groundwaters with some local recharge; however, the amount of each component varied widely depending on the data set. For the mixtures with the best agreement between the geochemical and isotopic data, the component of Frenchman Flat LCA making up the downgradient groundwater in the LCA at Army \#1 Water Well on the southern boundary of the NTS was relatively small, from three to 14 percent. Dissolved inorganic ${ }^{14} \mathrm{C}$ travel times calculated by geochemical modeling for southwest flow out of the Frenchman Flat LCA to the southern NTS boundary ranged from 4,300 to 6,800 years.

The interpretations in this report, based on geochemical and isotopic data, suggest that migration of radionuclides out of the alluvial and volcanic aquifers in Frenchman Flat into the LCA is unlikely. But, if radionuclides were to migrate into the LCA beneath Frenchman Flat, a viable groundwater flowpath from Frenchman Flat to the southern boundary of the NTS probably exists. The best geochemical models indicate that any Frenchman Flat LCA groundwater flowing to the southern boundary of the NTS is significantly diluted with groundwater from the Spring Mountains. Geochemical modeling and $\mathrm{DI}^{14} \mathrm{C}$ predict that it would take roughly 5,000 years for Frenchman Flat LCA groundwater to migrate to the southern NTS boundary. However, it is important to note that the interpretations of this report are limited by the uneven spatial distribution of wells within the study area and by a paucity of wells completed in the LCA, both in and downgradient of Frenchman Flat.

\section{REFERENCES}

Benedict, F.C., Jr., T.P. Rose, J.M. Thomas, R. Waddell and R. Jacobson, 2003. Geochemistry Technical Basis Document. Desert Research Institute, Division of Hydrologic Sciences Publication No. 45205, 32 p.

Blankennagel, R.K. and J.E. Weir, 1973. Geohydrology of the eastern part of Pahute Mesa, Nevada Test Site, Nye County, Nevada. U.S. Geological Survey Professional Paper 712$\mathrm{B}, 35 \mathrm{p}$.

Borg, I.Y., R. Stone, H.B. Levy and L.D. Ramspott, 1976. Information pertinent to the migration of radionuclides in groundwater at the Nevada Test Site. Part 1: Review and analysis of existing information. Lawrence Livermore National Laboratory, UCRL-52078, $216 \mathrm{p}$.

Bowen, S.M., P.L. Baca, L.F. Olivas, C.G. Geoffrion, J.L. Thompson, C.M. Miller, W. Goishi, B.K. Esser, J.W. Meadows, N. Namboodiri, D.K. Smith and J.K. Wild, 1994. Nevada Test Site Radionuclide Inventory, 1955-1992. Classified Report, Los Alamos National Laboratory, LA-CP-94-0226.

Burke, W.H., R.E. Denison, E.A. Hetherington, R.B. Koepnick, N.F. Nelson and J.B. Otto, 1982. Variation of seawater ${ }^{87} \mathrm{Sr} /{ }^{86} \mathrm{Sr}$ throughout Phanerozoic time. Geology, 10, p. 516519.

Chapman, J.B. and B.F. Lyles, 1993. Groundwater chemistry at the Nevada Test Site: Data and preliminary interpretations. Desert Research Institute, Water Resources Center Publication No. 45100, 45 p.

Craig, H., 1961. Isotopic variations in metoric waters. Science, 133, 1702-1703. 
Dansgaard, W., 1964. Stable Isotopes in precipitation. Tellus, 16, 436-468.

Fabryka-Martin, J., S.J. Wightman, W.J. Murphy, M.P. Wickham, M.W. Caffee, G.J. Nimz, J.R. Southon and P. Sharma, 1993. Distribution of chlorine-36 in the unsaturated zone at Yucca Mt.: An indicator of fast transport paths. FOCUS'93: Site Characterization and Model Validation, Las Vegas, NV, 26-29 September 1993.

Federal Facility Agreement and Consent Order (FFACO), 1996. Remediation strategy document agreed to by the State of Nevada, the U.S. Department of Energy, and the U.S. Department of Defense.

French, R.H., 1983. A preliminary analysis of precipitation in southern Nevada. Desert Research Institute, Water Resources Center Publication No. 45031.

French, R.H., 1985. Daily, seasonal and annual precipitation at the Nevada Test Site, Nevada. Desert Research Institute, Water Resources Center Publication No. 45042.

Frizzell, V.A. and J. Shulters, 1990. Geologic map of the Nevada Test Site, southern Nevada. U.S. Geological Survey Miscellaneous Investigation Map I-2046, scale 1:100,000.

Harril J.R., J.S. Gates and J.M. Thomas, 1988. Major ground-water flow systems in the Great Basin region of Nevada, Utah, and adjacent states. U.S. Geological Survey Hydrologic Investigations Atlas HA-694-C.

Hershey, R.L. and S.Y. Acheampong, 1997. Estimation of groundwater velocities from Yucca Flat to the Amargosa Desert using geochemistry and environmental isotopes. Desert Research Institute, Water Resources Center Publication No. 45157, 31 p.

Hershey, R.L., 1989. Hydrogeology and hydrogeochemistry of the Spring Mountains, Clark County, Nevada. Masters thesis, University of Nevada, Las Vegas, 237 p.

Ingraham, N.L., R.L. Jacobson, J.W. Hess and B.F. Lyles, 1990. Stable isotopic study of precipitation and spring discharge on the Nevada Test Site. Desert Research Institute, Water Resources Center Publication No. 45078, 55 p.

IT Corporation, 2001. Modeling Approach for Corrective Action Unit 98, Frenchman Flat, Rev. 0, March 2001. ITLV/13052-141.

Johnson, R.H., 1986. U.S. Geological Survey tracer study, Amargosa Desert, Nye County, Nevada, Part 1: Exploratory drilling, tracer well construction and testing, and preliminary findings. U.S. Geological Survey Open-File Report.

Johnson, T.M., R.C. Roback, T.L. McLing, T.D. Bullen, D.J. DePaolo C. Doughty, R.J. Hunt, R.W. Smith, L.D. Cecil and M.T. Murrell, 2000. Groundwater "fast paths" in the Snake River Plain aquifer: radiogenic isotope ratios as natural groundwater tracers. Geology, 28, 871-874.

Johnson, T.M. and D.J. DePaolo, 1994. Interpretation of isotopic data in groundwater-rock systems: model development and application to $\mathrm{Sr}$ isotope data from Yucca Mountain. Water Resources Research, 30, 1571-1587.

Laczniak, R.J., J.C. Cole, D.A. Sawyer and D.A. Trudeau, 1996. Summary of hydrogeologic controls on groundwater flow at the Nevada Test Site, Nye County, Nevada. U.S. Geological Survey Water-Resources Investigations Report 96-4109, 59 p. 
Lear, C.H., H. Elderfield and P.A. Wilson, 2003. A Cenozoic seawater $\mathrm{Sr} / \mathrm{Ca}$ record from benthic foraminiferal calcite and its application in determining global weathering fluxes. Earth Planet. Sci. Lett., 208, 69-84.

Lyles, B.F. and J.W. Hess, 1988. Isotope and ion geochemistry in the vicinity of the Las Vegas shear zone. Desert Research Institute, Water Resources Center Publication No. $41111,78 \mathrm{p}$.

Lyles, B.F., W.A. McKay, J.B. Chapman and S.W. Tyler, 1991. Hydrogeologic characterization of wells HTH-1, UE18r, UE6e, and HTH-3, Nevada Test Site. Desert Research Institute, Water Resources Center Publication No. 45087, 73 p.

Lyles, B.F., 1990. Tritium variations in groundwater on the Nevada Test Site. Desert Research Institute, Division of Hydrologic Sciences Publication No. 45086. Las Vegas, NV.

Lyles, J. Edkins, R.L. Jacobson and J.W. Hess, 1990. Time-series analysis of ion and isotope geochemistry of selected springs of the Nevada Test Site, Nye County, Nevada. Desert Research Institute, Water Resources Center Publication No. 45068, 121 p.

Marshall, B.D. and K. Futa, 2001. Strontium isotope evolution of pore water and calcite in the Topopah Spring Tuff, Yucca Mountain, Nevada. Proceedings of the Ninth International High-Level Radioactive Waste Management Conference, Las Vegas, NV, April 29 - May 3, 2001, American Nuclear Society, LaGrange Park, IL, published on CD-ROM.

Marshall, B.D. and S.A. Mahan, 1994. Strontium isotope geochemistry of soil and playa deposits near Yucca Mountain, Nevada. Proceedings of the Fifth Annual International Conference, High-Level Radioactive Waste Management, Las Vegas, NV, May 22-26, 1994, American Nuclear Society, LaGrange Park, IL, p. 2685-2691.

Mifflin, M.D. and J.W. Hess, 1979. Regional carbonate flow systems in Nevada, in Back, William, and Stephenson, D.A., eds., Contemporary hydrogeology, the George Burke Maxey memorial volume: Journal of Hydrology, 43, p. 217-237.

Mook, W.G., 1980. Carbon-14 in hydrogeological studies. In: P. Fritz and J.Ch. Fontes, eds., Handbook of Environmental Isotope Geochemistry, Volume 1, The Terrestrial Environment. Elsevier, Amsterdam, pp. 49-74.

Moran, J.E. and T.P. Rose, 2003. A chlorine-36 study of regional groundwater flow and vertical transport in southern Nevada. Environmental Geology, 43, 592-605.

Nader, F.H., R. Swennen and R. Ellam, 2004. Reflux stratabound dolostone and hydrothermal volcanism-associated dolostone: a two-stage dolomitization model (Jurassic, Lebanon). Sedimentology, 51, 339-360.

Parkhurst, D.L and C.A.J. Appelo, 1999. User's guide to PHREEQC (Version 2)-a computer program for speciation, batch-reaction, one-dimensional transport, and inverse geochemical calculations. U.S. Geological Survey, Water-Resources Investigations Report 99-4259, $312 \mathrm{p}$. 
Pawloski, G.A., A.F.B. Tompson, C.J. Bruton and M. Zavarin (eds.), 2000. Evaluation of the Hydrologic Source Term from Underground Nuclear Tests in Frenchman Flat at the Nevada Test Site (U). Contributors: W.L. Bourcier, C.J. Bruton, S.F. Carle, B.K. Esser, A.B. Kersting, R.M. Maxwell, G.A. Pawloski, J.A. Rard, D.E. Shumaker, D.K. Smith, A.F.B. Tompson and M. Zavarin, UCRL-ID-138007, Lawrence Livermore National Laboratory, CA.

Peterman, Z.E., B.L. Widmann, B.D. Marshall, J.N. Aleinikoff, K. Futa and S.A. Mahan, 1994. Isotopic tracers of gold deposition in Paleozoic limestones, southern Nevada: Proceedings of the Fifth Annual International Conference, High-Level Radioactive Waste Management, Las Vegas, NV, May 22-26, 1994, American Nuclear Society, LaGrange Park, IL, p. 1316-1323.

Peterman, Z.E., R.W. Spengler, F.R. Singe and R.P. Dickerson, 1993. Isotopic and trace element variability in altered and unaltered tuffs at Yucca Mountain, Nevada. Proceedings of the Fourth Annual International Conference, High-Level Radioactive Waste Management, Las Vegas, NV, April 26-30, 1993, American Nuclear Society, LaGrange Park, IL, p. 1940-1947.

Peterman, Z.E. and P.L. Cloke, 2002. Geochemistry of rock units at the potential repository level, Yucca Mountain, Nevada. Applied Geochem., 17, p. 683-698.

Peterman, Z.E. and Kiyotot Futa, 1996. Geochemistry of core samples of the Tiva Canyon tuff from drill hole UE-25 NRG\#3, Yucca Mountain, Nevada. U.S. Geological Survey Open-File Report 95-325, 19 p.

Peterman, Z.E., C.E. Hedge and H.A. Tourtelot, 1970. Isotopic composition of strontium in sea water throughout Phanerozoic time. Geochim. Cosmochim. Acta 34, 105-120.

Peterman, Z.E., R.W. Spengler, F.R. Singer and R.P. Dickerson, 1996. Geochemistry of outcrop samples from the Raven Canyon and Paintbrush Canyon reference sections, Yucca Mountain, Nevada. U.S. Geological Survey Open-File Report 94-550, 17p.

Plummer, L.N., E.C. Prestemon and D.L. Parkhurst, 1994. An interactive code (NETPATH) for modeling net geochemical reactions along a flowpath, Version 2.0. U.S. Geological Survey, Water-Resources Investigations Report 94-4169, 130 p.

Prudic, D.E., J.R. Harrill and T.J. Burbey, 1995. Conceptual evaluation of regional groundwater flow in the carbonate-rock province of the Great Basin, Nevada, Utah, and adjacent states. U.S. Geological Survey Professional Paper 1409-D, 102 p.

Rose, T.P., F.C. Benedict Jr., J.M. Thomas, W.S. Sicke, R.L. Hershey, J.B. Paces, I.M. Farnham and Z.E. Peterman, 2002. Geochemical data analysis and interpretation of the Pahute Mesa-Oasis Valley groundwater flow system, Nye County, Nevada. Lawrence Livermore National Laboratory, preliminary report prepared for the U.S. Department of Energy, Nevada Operations Office, Environmental Restoration Division, August 2002, $607 \mathrm{p}$.

Savard, C.S., 1996. Selected hydrologic data from Fortymile Wash in the Yucca Mountain area, Nevada, water years 1993-94. U.S. Geological Survey Open-File Report 95-709. 30 p. 
Schoff, S.L. and J.E. Moore, 1964. Chemistry and movement of groundwater, Nevada Test Site. U.S. Geological Survey Report, TEI-838, 75p.

Simpson, E.S., D.B. Thorud and I. Friedman, 1972. Distinguishing seasonal recharge to groundwater by deuterium analysis in southern Arizona. Proceedings Reeding Symposium, International Association of Science Hydrology, 113-121.

Spencer, E.B. 1990. A radiocarbon study of groundwater in the western Nevada Test Site and Vicinity. University of Nevada, Reno, Masters thesis, 124 p.

Stoller-Navarro Joint Venture (SNJV), 2004. Geochem03.mdb and a user's guide to the comprehensive water quality database for groundwater in the vicinity of the Nevada Test Site. Rev. 5, February 2004 (unpublished data).

Thomas, J.M., F.C. Benedict, Jr., T.P. Rose, R.L. Hershey, J.B. Paces, Z.E. Peterman, I.M. Farnham, K.H. Johannesson, A.K. Singh, K.J. Stetzenbach, G.B. Hudson, J.M. Kenneally, G.F. Eaton and D.K. Smith, 2002. Geochemical and isotopic interpretations of groundwater flow in the Oasis Valley Flow System, Southern Nevada. Desert Research Institute, Division of Hydrologic Sciences Publication No. 45190, Reno, Nevada.

Thomas, J.M., A.H. Welch and M.D. Dettinger, 1996. Geochemistry and isotope hydrology of representative aquifers in the Great Basin region of Nevada, Utah, and adjacent states. U.S. Geological Survey Professional Paper 1409-C, 100 p.

U.S. Department of Energy (US DOE). 1999. Corrective Action Investigation Plan for Corrective Action Unit 98: Frenchman Flat, Nevada Test Site, Nevada, DOE/NV-478Rev.1, July 1999.

U.S. Department of Energy (US DOE). 1997. Regional Groundwater Flow and Tritium Transport Modeling and Risk Assessment of the Underground Test Area, Nevada Test Site, Nevada, DOE/NV- 47, October 1997.

Warren, R.G, F.C. Benedict Jr., T.P. Rose, D.K. Smith, S.J. Chipera, E.C. Kluk and K.M. Raven, 2002. Alluvial layering and distribution of reactive phases within drill holes ER5/4 and UE5N of Frenchman Flat. LA-UR-02-6206, Los Alamos National Laboratory, Los Alamos, New Mexico.

Winograd, I.J., A.C. Riggs and T.B. Coplen, 1998. The relative contribution of summer and cool-season precipitation to groundwater recharge, Spring Mountains, Nevada, USA. Hydrogeology Journal, 6(1), 77-93.

Winograd, I.J. and F.J. Pearson, Jr., 1976. Major carbon-14 anomaly in a regional carbonate aquifer: Possible evidence for megascale channeling, south-central Great Basin. Water Resources Research, 12, 1125-1143.

Winograd, I.J. and W. Thordarson, 1975. Hydrogeologic and hydrochemical framework, south-central Great Basin, Nevada-California, with special reference to the Nevada Test Site. U.S. Geological Survey Professional Paper 712-C, 126 p.

Winograd, I.J. and I. Friedman, 1972. Deuterium as a tracer of regional groundwater flow, southern Great Basin, Nevada and California. Geological Society of America Bulletin, 83, 3691-3708. 